University of Nebraska - Lincoln

DigitalCommons@University of Nebraska - Lincoln

2003

Stratigraphy, geochronology, and accretionary terrane settings of two Bronson Hill arc sequences, northern New England

Robert H. Moench

U.S. Geological Survey, bsmoench@indra.com

John N. Aleinikoff

U.S. Geological Survey

Follow this and additional works at: https://digitalcommons.unl.edu/usgsstaffpub

Part of the Earth Sciences Commons

Moench, Robert H. and Aleinikoff, John N., "Stratigraphy, geochronology, and accretionary terrane settings of two Bronson Hill arc sequences, northern New England" (2003). USGS Staff -- Published Research. 436. https://digitalcommons.unl.edu/usgsstaffpub/436

This Article is brought to you for free and open access by the US Geological Survey at DigitalCommons@University of Nebraska - Lincoln. It has been accepted for inclusion in USGS Staff -- Published Research by an authorized administrator of DigitalCommons@University of Nebraska - Lincoln. 


\title{
Stratigraphy, geochronology, and accretionary terrane settings of two Bronson Hill arc sequences, northern New England 败, 败弥
}

\author{
Robert H. Moench ${ }^{\mathrm{a}, *}$, John N. Aleinikoff ${ }^{\mathrm{b}}$ \\ a US Geological Survey, MS 905, Federal Center, Denver, CO 80225, USA \\ ${ }^{\mathrm{b}}$ US Geological Survey, MS 963, Federal Center, Denver, CO 80225, USA
}

\begin{abstract}
The Ammonoosuc Volcanics, Partridge Formation, and the Oliverian and Highlandcroft Plutonic Suites of the Bronson Hill anticlinorium (BHA) in axial New England are widely accepted as a single Middle to Late Ordovician magmatic arc that was active during closure of Iapetus. Mapping and $\mathrm{U}-\mathrm{Pb}$ dating indicate, however, that the BHA contains two volcano-sedimentary-intrusive sequences of probable opposite subduction polarity, here termed the Ammonoosuc and Quimby sequences.

The Ammonoosuc sequence is defined by the Middle Ordovician Ammonoosuc Volcanics near Littleton, NH, the type area, northeast to Milan, NH, and Oquossoc, ME; it also includes black slate of the Partridge Formation (C. bicornis-zone graptolites, $\sim 457 \mathrm{Ma}$ ). Related metamorphosed intrusives are the tonalitic Joslin Turn pluton (469 $\pm 2 \mathrm{Ma})$, the Cambridge Black granitic pluton (468 $\pm 3 \mathrm{Ma})$, and gabbro, tonalite $(467 \pm 4 \mathrm{Ma})$, and sheeted diabase of the Chickwolnepy intrusions. These intrusives cut lowermost Ammonoosuc (therefore $>469 \mathrm{Ma}$ ). Probable uppermost Ammonoosuc is dated at $465 \pm 6$ and $461 \pm 8$ Ma. Successively below the Ammonoosuc are the Dead River and Hurricane Mountain Formations (flysch and melange), and the Jim Pond Formation (484 \pm 5 Ma) and Boil Mountain Complex (both ophiolite), which are structurally underlain by the Neoproterozoic(?) Chain Lakes massif.

The Quimby sequence is defined by the Lower Silurian(?) to Upper Ordovician Quimby Formation, composed of bimodal volcanics (443 $\pm 4 \mathrm{Ma}$ ) and sulfidic shale and graywacke that lie conformably to unconformably above the Ammmonoosuc Volcanics and Partridge Formation. Also in the Quimby sequence are several granitic to sparsely gabbroic plutons of the Highlandcroft (441$452 \mathrm{Ma}$ ) and Oliverian (435-456 Ma) Plutonic Suites, which intrude the Dead River, Ammonoouc and Partridge, but not the Quimby Formation.

Based on faunal, paleolatitude, and isotopic data, the Ammonoosuc sequence and its correlatives and underlying sequences formed off the southern Laurentian margin, but northwest of the principal Iapetan suture, or Red Indian line. The Boil MountainJim Pond-Hurricane Mountain sequence was ramped northwestward over the Chain Lakes massif at $\sim 475 \mathrm{Ma}$, on the basal Boil Mountain surface. This obduction probably occurred slightly before obduction on the Baie Vert-Brompton surface (BBL), farther NW, over the Laurentian margin, and was followed by Dead River flysch sedimentation, which ended with the abrupt onset of Ammonoosuc-sequence arc magmatism at 470 Ma. Ammonoosuc eruptions probably ended at 460 Ma, when Iapetus closed along the Red Indian line.

During a following magmatic hiatus of $\sim 3-5$ m.y., now represented by portions of the Partridge Formation that overlie the Ammonoosuc Volcanics, subduction polarity reversed, and subduction resumed below the northwest-dipping Brunswick subduction complex (BSC) of New Brunswick, Canada. Quimby-sequence magmatism ( 456-435 Ma) on the newly accreted Laurentian margin occurred above the BSC, whose footwall is now buried to the southeast by mainly Silurian clastic sediments of the MerrimackFredericton trough, deposited in the "Fredericton Sea". In Silurian to Early Devonian time, the NW-dipping BSC footwall was paired with a SE-dipping subduction zone that produced arc magmas of the Coastal Volcanic belt, built on the composite Avalon and adjacent peri-Avalonian terranes. Orogen-normal extension produced by rapid rollback of both subduction zones narrowed the Fredericton Sea, produced the Central Maine and Connecticut Valley-Gaspé basins, and culminated in the Acadian orogeny when the sea completely closed in Early Devonian time.

Published by Elsevier Science Ltd.
\end{abstract}

\footnotetext{
${ }^{2}$ PII of original article S1474-7065(01)00003-1; doi of erratum article 10.1016/S1474-7065(03)00013-5.

Publication authorized by the Director, US Geological Survey.

${ }^{*}$ Corresponding author. Tel.: +1-303-236-5651; fax: +1-303-236-7884.

E-mail address: bsmoench@indra.com (R.H. Moench).
} 


\section{Introduction}

This paper attempts to relate our understanding of Early Paleozoic stratigraphy and geochronology in northern New Hampshire and western central Maine (Figs. 1 and 2) to the Late Cambrian(?) to Early Devonian plate-tectonic evolution of a larger part of the northern Appalachians. In order to accomplish this task it was necessary to investigate earlier depictions of accreted terrane structure (e.g. Zen, 1989; Stewart et al., 1993) and to derive a terrane delineation that accommodates the evidence as we see it. Fig. 1 shows the results; supporting evidence and arguments are given below in the "Proposed delineation of accreted terranes" section. Our compilation of terrane structure was guided by the principle that an accreted terrane consists of continental and/or oceanic basement and covering deposits and intrusives that were emplaced before or during accretion to another terrane. Accordingly, postaccretionary deposits cannot enter into the definition of an accreted terrane; they may (and do) cross terrane boundaries.

The detailed focus of this paper is on the stratigraphy and plutonic geology exposed in the northern portion of the Bronson Hill belt (Figs. 2-4), which includes parts of the Bronson Hill anticlinorium mainly north of the 44th parallel, and contiguous parts of the Boundary Mountains and Lobster Mountain anticlinoriums. Based on mapping and $\mathrm{U}-\mathrm{Pb}$ geochronology, we propose that the Bronson Hill arc of other researchers (e.g. Stanley and Ratcliffe, 1985; Tucker and Robinson, 1990; Robinson et al., 1998) is actually composed of two, probably unrelated volcano-sedimentary-intrusive sequences, here informally referred to as the Ammonoosuc sequence (Middle Ordovician, composed of the Ammonoosuc Volcanics and the Joslin Turn and Cambridge Black
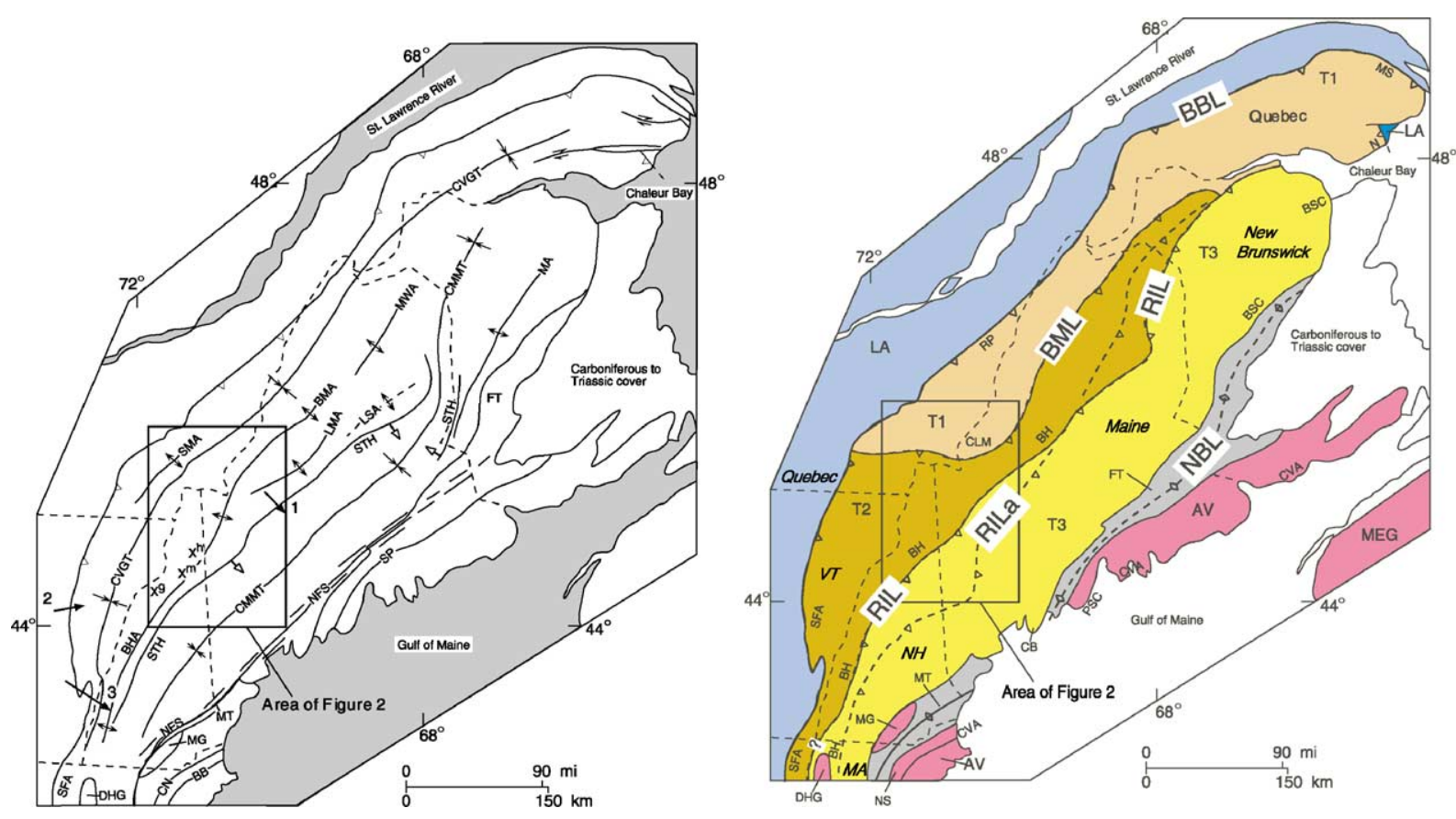

Fig. 1. Proposed basement terranes, sutures, and superimposed tectonic features of northern New England and mainland Canada. See "Proposed delineation of accreted terranes" in text. States of USA-MA, Massachusetts; NH, New Hampshire; VT, Vermont. Explanation righthand map: Proposed accreted terranes, magmatic arcs, and plate sutures. Terranes: LA, Laurentia (Humber zone). T1, terrane 1 (NW part of Notre Dame zone); Chain Lakes massif (CLM), and correlatives at Riviere des Plante (RP), Mont Serpentine (MS), and Nadeau (N), Quebec. T2, terrane 2 (SE part of Notre Dame zone). T3, terrane 3 (Exploits and Gander zones, undivided), showing locations of Casco Bay belt, CB, Massabesic Gneiss Complex, MG, and Dry Hill and related gneisses of Pelham dome, DHG. AV, composite Avalon "proper" and adjacent peri-Avalonian belts; tentatively includes Meguma terrane, MEG, and Putnam-Nashoba belt, NS. Arcs and subduction complexes: SFA, Shelburne Falls arc; BH, superposed arcs (Ammonoosuc + Quimby) of Bronson Hill belt; CVA, coastal volcanic arc; BSC, Brunswick subduction complex; PSC, Penobscot suduction complex. Sutures: BBL, Baie Verte-Brompton line. BML, Boil Mountain line. RIL, proposed buried Red Indian line. RILa, alternative placement of RIL. NBL, New Brunswick line; proposed occluded divergent subduction boundaries buried under FT and MT. Lefthand map: includes BBL from righthand map, Anticlinoria: approximate crestline-SMA, Stoke Mountain; BHA, Bronson Hill; BMA, Boundary Mountains; LMA, Lobster Mountain; MWA, Munsungun-Winterville; LSA, Lunksoos; MA, Miramichi. Sedimentary troughs: approximate troughline - CVGT, Connecticut Valley-Gaspé; CMMT, Central Maine-Matapedia; FT MT, Fredericton and Merrimack. Silurian tectonic hinge: STH, arrows point to thicker Silurian deposits of CMMT. Faults: NFS, Norumbega fault system; CN, Clinton-Newbury; BB, Bloody Bluff, Sp, Sennebec Pond. $\rightarrow \mathbf{1}$ Southeast edge of Grenville basement: 1, Stewart et al. (1993); 2, Hughes and Luetgert (1991); 3, Ando et al. (1984). Xh Vms deposits having strongly radiogenic lead: $\mathbf{X}^{\mathbf{h}}$, Hampshire Hills; $\mathbf{X}^{\mathbf{m}}$, Milan; $\mathbf{X}^{\mathbf{g}}$, Gardner Mountain. From Slack et al. (1991). 


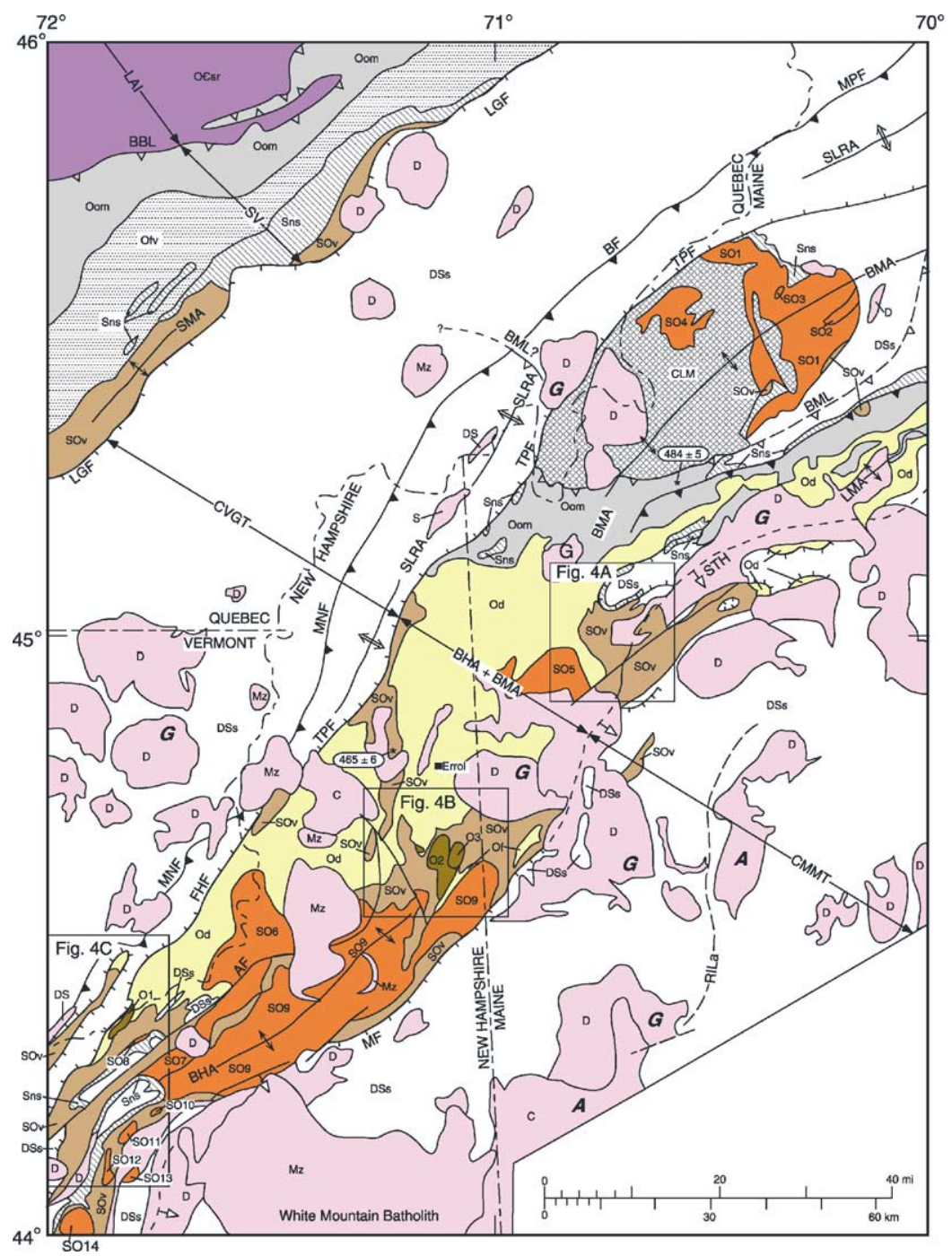

Fig. 2. Geologic map of the Sherbrooke and Lewiston $1^{\circ} \times 2^{\circ}$ quadrangles, United States and Canada. Modified from St. Julien and Slivitsky (1987), Tremblay and Pinet (1994), Lebel and Tremblay (1993) and Moench et al. (1995, 1999). Sites of recent U-Pb zircon ages: Ammonoosuc Volcanics, 10 km NW of Errol, NH (Moench and Aleinikoff, 2001, $465 \pm 6$ Ma); Jim Pond Formation, near south edge of Chain Lakes massif, ME (Moench et al., 2000, $484 \pm 5$ Ma). Explanation: Mz, Mesozoic to Silurian plutons and dike complexes-Mz, Mesozoic; C, Carboniferous; D, Devonian; DS, Devonian and Silurian; S, Silurian. SO1-14, Silurian and Late Ordovician plutons of Quimby sequence-Highlandcroft and Oliverian Plutonic Suites. Highlandcroft: 1, Attean; 2, Catheart Mountain; 3, Sally Mountain; 4 Skinner; 5, Adamstown; 6, Lost Nation; 7, Whitefield; 8, Highlandcroft. Oliverian: 9, Jefferson batholith; 10, Sugar Hill; 11, Landaff; 12, Moody Ledge; 13, Tunnel Brook; 14, Owls Head. O1-O3, Middle Ordovician plutons of Ammonoosuc sequence-1, Joslin Turn; 2, Chickwolnepy intrusions; 3, Cambridge Black. DSs, Lower Devonian and Silurian successor basin deposits, undivided-Silurian rift-basin deposits of CVGT, and CMMT, and lower Devonian cover sequence. Sns, Silurian nearshore deposits-Exposed along anticlinoria; lower contacts unconformable. Fitch Formation, Clough Quartzite, and correlatives. SOv, Lower Silurian to Middle Ordovician volcanic-bearing Quimby and Ammonoosuc sequences, undivided, of Bronson Hill belt, and Ascot Complex, Quebec. Ofv, Lower Upper to Lower Ordovician fore-arc flysch and volcanics-Magog Group, Quebec. Od, Lower Middle and Lower Ordovician flyschDead River Formation and correlatives. Oom, Middle(?) to Lower Ordovician melange and ophiolite-St. Daniel Formation and Thetford Mines ophiolite, Quebec; Hurricane Mountain and Jim Pond Formations, Boil Mountain Complex, Maine. Ocsr, Middle Ordovician to Cambrian slope and rise deposits, Quebec-Formations of external and internal nappes of Laurentian margin, Quebec. CLM, Upper Neoproterozoic Chain Lakes massif. $A F$, Triassic and Devonian late faults-Triassic normal fault, AF, Ammonoosuc, downthrown on northwest. Devonian thrust fault, teeth on upthrown side; MNF, Monroe; BF, Bella (Lebel and Tremblay, 1993); MPF, Marie Petuche. FHF, Early Devonian and Silurian early normal faults-FHF, Foster Hill; MF, Mahoosuc; LGF, La Guadeloupe; TPF, Thrasher Peaks. Ticks on downthrown side. LGF and TPF reactivated by Acadian thrusting (Cousineau and Tremblay, 1993) and strike-slip (Marvinney, 1989). BBL, Terrane suture, open triangles on side of inferred dip; dashed where conjectural: BBL, Baie Verte-Brompton; BML, Boil Mountain; RILa, alternative Red Indian line based on distribution of geochemically distinguished Grenville-source, $\boldsymbol{G}$, and peri-Avalon-source, $\boldsymbol{A}$, Devonian plutons (Dorais and Paige, 1999). BHA, approximate axial trace of anticlinorium: SMA, Stoke Mountain; BHA, Bronson Hill; BMA, Boundary Mountains; LMA, Lobster Mountain. $\leftarrow$ LAI $\rightarrow$ Principal tectonic belts, arrows point to margins: LAI, internal nappes of Laurentia; SV, St. Victor synclinorium and adjacent belts; CVGT, Connecticut Valley-Gaspé trough; BHA + BMA, Bronson Hill and Boundary Mountains anticlinoria; CMMT, Central Maine-Matapedia trough. STH, Silurian tectonic hinge-Dashed across Devonian plutons; arrow points to thicker Silurian deposits of CMMT. SLRA, Silurian magmatic axis of Second Lake rift; arrows indicate direction of spreading. 


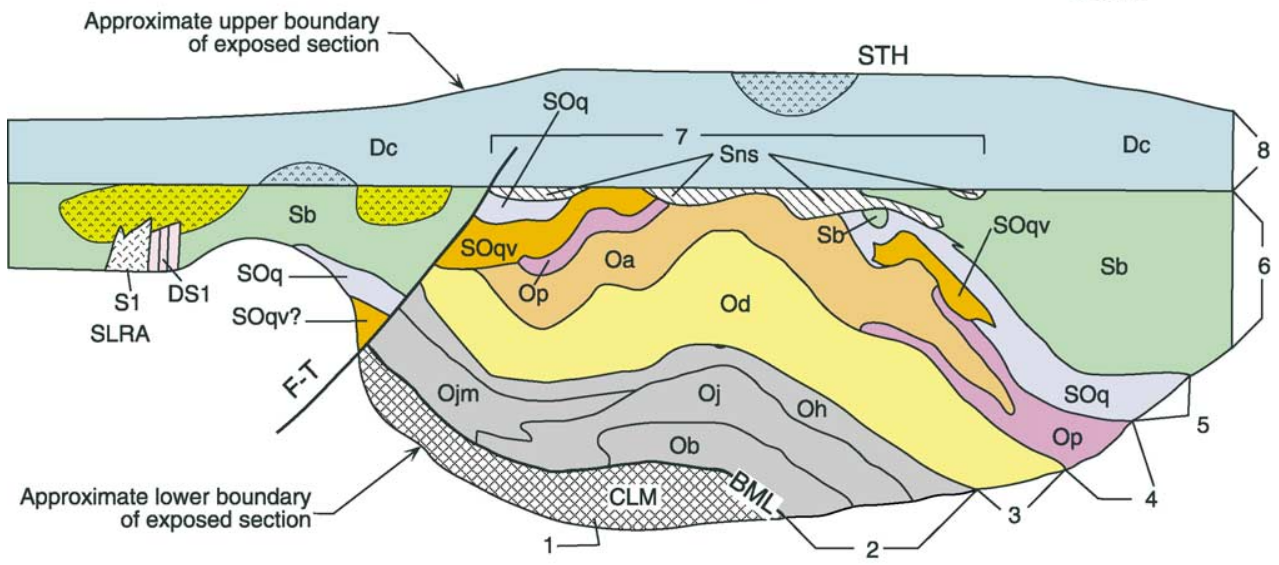

Fig. 3. Diagramatic stratigraphic sequence from Connecticut Valley-Gaspé trough (CVGT) to Central Maine-Matapedia trough (CMMT). Random $\mathrm{v}$ pattern indicates Silurian-Devonian volcanic rocks. Explanation: Unit 8 Dc, Lower Devonian pelitic to psammitic and locally volcanic cover sequence-Littleton and Compton Formations and Seboomook Group. Unit 7 Sns, Silurian near-shore deposits-Clough Quartzite, Fitch Formation, and correlatives. Unit $6 \mathrm{Sb}$, Silurian turbidite basin sequence-Greenvale Cove, Rangeley, Perry Mountain, Smalls Falls and Madrid Formations of CMMT and CVGT, and Early Devonian? and Silurian volcanic and calc-psammite of Frontenac Formation. Unit 5 Lower Silurian and Upper Ordovician Quimby sequence: SOq, Black shale and graywacke of Quimby Formation; SOqv, Bimodal volcanics of Quimby Formation. Unit 4 Lower Upper and Middle Ordovician Ammonoosuc sequence: Op, Upper and Middle Ordovician Partridge Formation-Black sulfidic shale; Oa, Middle Ordovician Ammonoosuc Volcanics. Unit 3 Od, Lower Middle and Lower Ordovician Dead River Formation-Flysch sequence deposited after obduction of Unit 2 over CLM. Unit 2 Lower Ordovician strataform ophiolite and ophiolitic melange: Oh, Hurricane Mountain Formation-Euxinic trench melange; Ojm, Magalloway Member of Jim Pond Formation—Resedimented ophiolite; Oj, Jim Pond FormationBimodal volcanic member of ophiolite; Ob, Boil Mountain Complex-Stratiform mafic-ultramafic plutonic member of ophiolite. Unit 1 CLM, Neoproterozoic(?) Chain Lakes basement massif-Metamorphosed sedimentary diamictite and related plutonic rocks. Tectonic features: CVGT, CMMT, Connecticut Valley-Gaspé and Central Maine-Matapedia troughs; BHA+BMA, Bronson Hill and Boundary Mountains anticlinoria; STH, Silurian tectonic hinge at west side of CMMT; F-T, Foster Hill-Thrasher Peaks line-Pre-Acadian basin-margin normal fault, deformed and reactivated during Acadian; BML, Boil Mountain obduction surface. SLRA Magmatic axis of Second Lake rift of CVGT; DS, Early Devonian or Silurian Marble Mountain bimodal sheeted dike body; S, Silurian East Inlet granophyric pluton.

plutons and the Chickwolnepy intrusions) and the Quimby sequence (Upper Ordovician and Lower Silurian, composed of the Quimby Formation and the Highlandcroft and Oliverian Plutonic Suites).

This distinction of arc sequences explains the major age discrepancy between the Middle Ordovician type Ammonoosuc in the Northern portion of Bronson Hill belt, and Upper Ordovican rocks previously mapped in the southern portion as the Ammonoosuc Volcanics and Partridge Formation (Tucker and Robinson, 1990). The northern and southern portions of the Bronson Hill belt also differ with regard to their respective pre-Ammonoosuc foundations. Whereas the southern portion, as exposed in the Pelham dome of Massachusetts, is structurally underlain by the Dry Hill Gneiss (Fig. 1, DHG) and related Neoproterozoic gneisses (Tucker and Robinson, 1990), the northern portion is underlain by mainly Lower Ordovician flysch (Dead River Formation), melange (Hurricane Mountain Formation), bimodal ophiolitic volcanics (Jim Pond Formation), stratiform mafic-ultramafic rocks (Boil Mountain Complex), and the structurally underlying Chain Lakes massif (Figs. 2 and 3).
In the final section of this paper, entitled "Speculative accretionary and inter-accretionary events" we propose a model whereby the Middle Ordovician Ammonoosuc sequence was emplaced above a southeast-dipping subduction zone, along a magmatic arc that was built on a composite peri-Laurentian terrane (Fig. 1, T1 + T2), broadly correlated to the Notre Dame arc of Newfoundland (Williams et al., 1988). This occurred shortly before closure of Iapetus at $\sim 460 \mathrm{Ma}$. In contrast, we suggest that the Late Ordovician to Early Silurian Quimby sequence was emplaced on the newly accreted Laurentian margin shortly after closure.

This paper is based on mapping and related studies by many geoscientists since the publication M.P. Billing's classic studies in New Hampshire (Billings, 1937, 1956). Major revisions of the early work were made since 1978 as part of the Conterminous United States Mineral Assessment Program (CUSMAP) in the Lewiston and United States portion of the Sherbrooke $1^{\circ} \times 2^{\circ}$ quadrangles, or Sherbrooke-Lewiston project. Results of work done from 1978 to about 1993 are available on 1:250,000 scale maps and accompanying pamphlets 

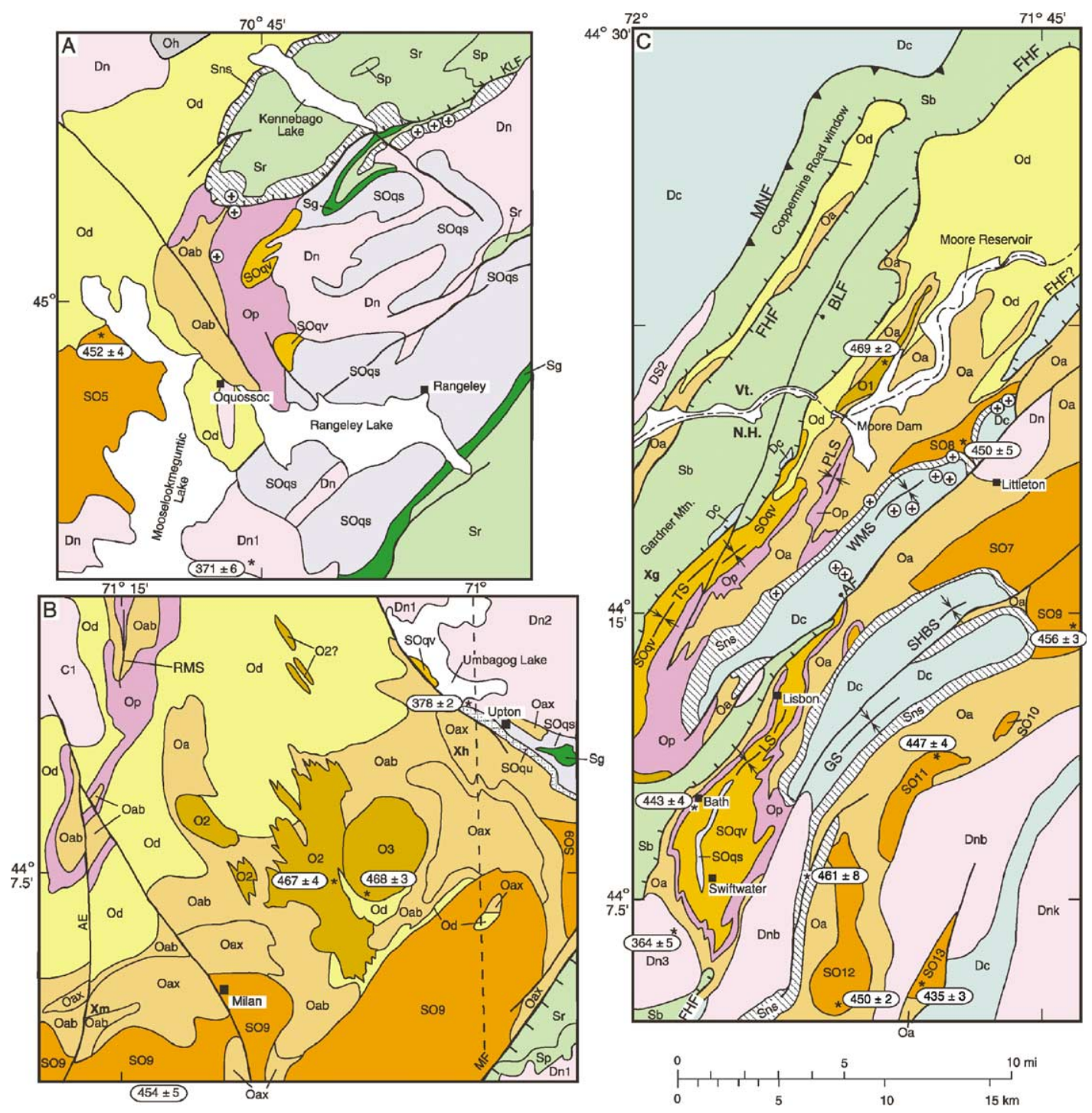

Fig. 4. Selected geologic maps of the northern Bronson Hill belt. A, Oquossoc area, compiled from Moench (1971), Harwood (1973), Guidotti (1977) and Boudette (1991). B, Milan area, modified from Milton (1961, 1968). C, Littleton area, modified from Billings (1935, 1937) and Eric and Dennis (1958). Explanation: $C l$ Long Mountain pluton (Carboniferous). Dn New Hampshire Plutonic Suite (Late to Early Devonian)-Cited bodies: Dn1, Mooselookmeguntic; Dn2, Umbagog; Dn3, French Pond; Dnb, Dnk, Bethlehem and Kinsman Granodiorites. DS2 Sheeted bimodal dikes in Waterford (Early Devonian? and Silurian). SO5 Highlandcroft and Oliverian Plutonic Suites of Quimby sequence (Early Silurian and Late Ordovician)_Highlandcroft: SO5, Adamstown; SO7, Whitefield; SO8, Highlandcroft pluton. Oliverian: SO9, Jefferson batholith; SO10, Sugar Hill; SO11, Landaff; SO12, Moody Ledge; SO13, Tunnel Brook. O1 Intrusions of Ammonoosuc sequence (Middle Ordovician)-O1, Joslin Turn pluton; O2, Chickwolnepy intrusions; O3, Cambridge Black pluton. Dc Cover sequence, undivided (Lower Devonian) — Gray shale, sandstone, and local volcanics of Littleton Formation and correlatives. Sns Near-shore deposits (Silurian)_Fossil-bearing calcareous rocks and conglomerate of Fitch Formation, Clough Quartzite, and shelf facies of Rangeley Formation. Sb Basin sequence, undivided (Silurian) - Sp, Perry Mountain Formation (mainly interbedded green shale and quartzite); may include Lower Devonian? and Silurian Frontenac Formation in Littleton area. Sr, Rangeley Formation (interbedded black shale and quartzite; local conglomerate). Sg, Greenvale Cove Formation (calc-psammite). Quimby Formation (Lower Silurian? and Upper Ordovician): $S O q s$, Shale and graywacke member; $S O q v$, Bimodal volcanic member; $S O q u$, Calcsilicate member at Upton. $O p$ Partridge Formation (lower Upper and Middle Ordovician)-Mainly black shale; local chert and silicate-iron-formation near lower contact. $O a$ Ammonoosuc Volcanics, undivided (Middle Ordovician). Oax Mixed bimodal facies. Oab Basalt-dominated facies. Od Dead River Formation (lower Middle and Lower Ordovician)_Flysch turbidites. Oh Hurricane Mountain Formation (Lower Ordovician) - Euxinic melange. $A F$ Faults-Triassic normal, bar and ball on downthrown side; AF, Ammonoosuc; BLF, Bill Little. Devonian thrust, teeth on upthrown side; MNF, Monroe. Early Devonian and Silurian younger-over-older normal fault or detachment, ticks on dowthrown side; FHF, Foster Hill; MF, Mahoosuc; KLF, Kennebago Lake. WMS Synclines-WMS, Walker Mountain; SHBS, Salmon Hole Brook; GS, Garnet Hill; PLS, Partridge Lake; LS, Lisbon; TS, Tinkerville; RMS, Rice Mountain. *469 \pm 2 Isotopic age determination (Ma)-Sources in Table 1 and Moench et al. (1995). + Fossil locality-Sites in Fig. 4A (sources in text): Op, north $C$ bicornis graptolites; Op, south Scoto-Appalachian brachiopod fragments; Sns, east 3 upper Llandoverian brachiopods. $X h$ VMS deposit containing strongly radiogenic lead (Slack et al., 1991)- $\mathbf{X}^{\mathbf{h}}$, Hampshire Hills prospect; $\mathbf{X}^{\mathbf{m}}$, Milan mine; $\mathbf{X}^{\mathbf{g}}$, Paddock mine on Gardner Mountain. 
SOUTH

PELHAM DOME

\section{PLUTONIC SUITES}

LITTLETON

MILAN
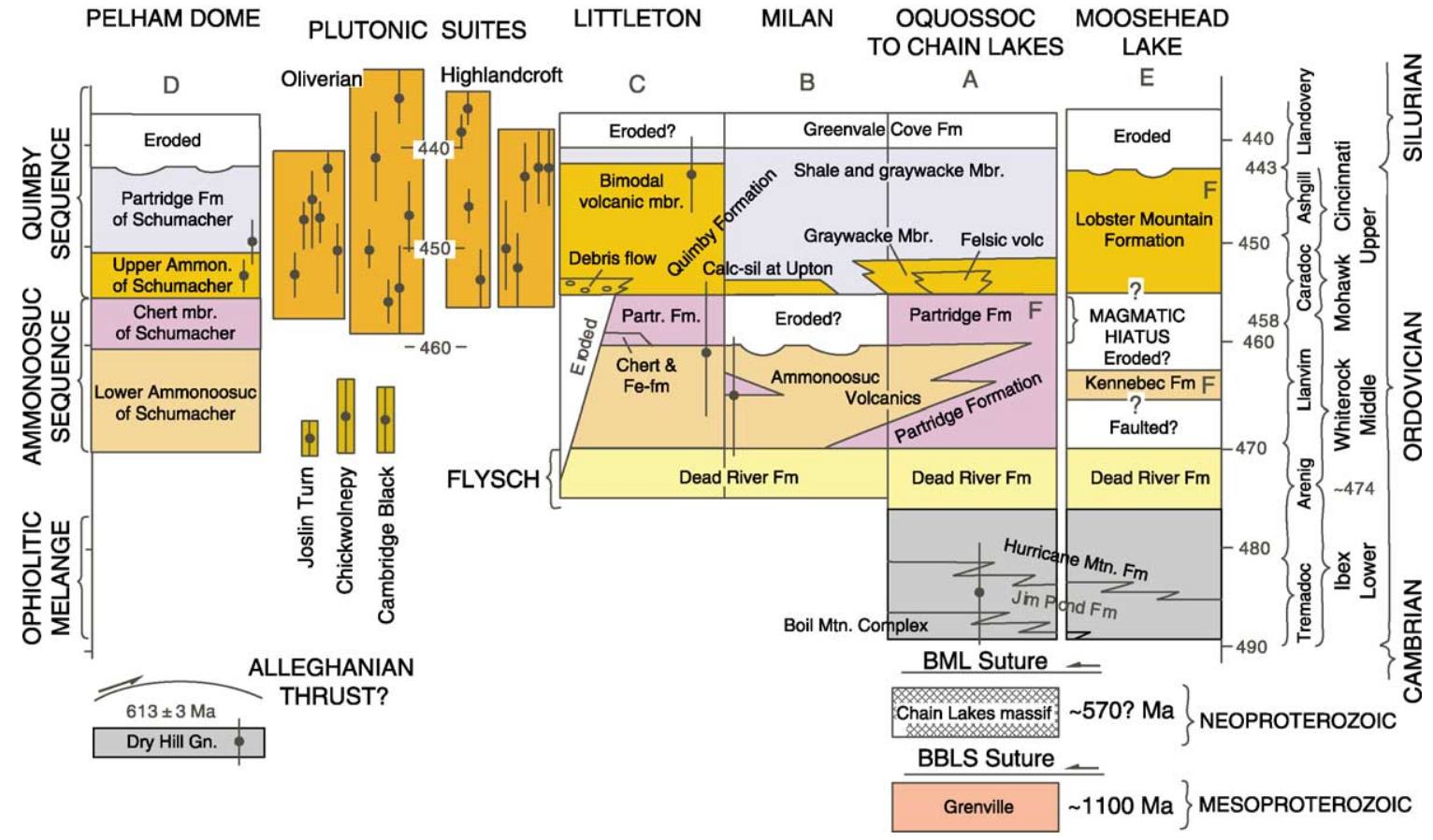

Fig. 5. Proposed correlations of Lower Silurian and Ordovician rocks from Moosehead Lake, Maine, to Pelham dome, Massachusetts. Compilations for columns A, B, C from this paper (Fig. 4), and references; for column D from Schumacher (1988); for column E modified from Boone et al. (1989, Fig. 1). F, fossil-dated unit (sources in text). Dot with vertical line, isotopic age and uncertainty: Sources for column C and righthand Highlandcroft column, and Joslin Turn, Chickwolnepy, and Cambridge Black intrusions, Table 1; for column D and lefthand Oliverian column, Tucker and Robinson (1990); for lefthand Highlandcroft column, Sevigny and Hanson (1995); for righthand Oliverian column, Lyons et al. (1986) and Table 1; and for Ammonoosuc Volcanics (column B) Moench and Aleinikoff (2001), and Jim Pond Formation (columns A), Moench et al. (2000).

(Moench et al., 1995, 1999). For complementary geologic, tectonic, geophysical, and mineral-resource information, readers are referred to Moench et al. (1999), prepared before we recognized the importance of the Red Indian line. Parts of these maps have been revised significantly since 1993, particularly along the Connecticut Valley (Moench, 1999; Moench and Aleinikoff, 2001).

The time scale of Tucker and McKerrow (1995) is used herein for most of Paleozoic time, but is modified to accommodate North American nomenclature for divisions of the Ordovician Period. Fig. 5 shows current North American and British Series nomenclature for the Ordovician, as modified by Fortey et al. (1995); an approximate time scale based on recent dating of the British Ordovician by U-Pb zircon methods (Tucker and McKerrow, 1995; Landing et al., 1997; Davidek et al., 1998); and brackets for Early (Ibex), Middle (Whiterock), and Late Ordovician (Mohawk + Cincinnati) time as informally used in this paper. We prefer our usage because it utilizes paleontologic boundaries that are precisely defined in the Great Basin (for example: Ross et al., 1998; Ross and Ethington, 1992; Finney and Ethington, 1992), and because it allows a significantly longer Middle Ordovician.

\section{U-Pb geochronology}

Table 1 lists $\mathrm{U}-\mathrm{Pb}$ ages for 13 samples of plutonic rocks and two samples of metavolcanic rocks exposed within or near the area of Fig. 2. The samples were collected between 1979 and 1989, in support of the Sherbrooke-Lewiston mapping. Most of the ages have been reported elsewhere (e.g., Moench et al., 1995), but without supporting analytical data and sample descriptions, which are given in Appendix A.

Billings (1937) and Hadley (1942), who mapped before the development of precise isotopic dating methods, proposed that most of the plutonic rocks in New Hampshire are Devonian in age. Naylor (1969), using the $\mathrm{Rb}-\mathrm{Sr}$ method, was the first to show that at least the Mascoma and Lebanon Oliverian plutons of west-central New Hampshire are Late Ordovician in age. Similarly, Foland and Loiselle (1981, and references), also using the $\mathrm{Rb}-\mathrm{Sr}$ method, obtained a surprising Late Ordovician to earliest Silurian age $(441 \pm 5 \mathrm{Ma})$ for syenite and quartz syenite exposed within the Oliverian Jefferson batholith, but previously mapped as part of the adjacent Jurassic Pilot-Pliny plutons. Naylor's and Foland and Loiselle's data were subsequently confirmed by 
Table 1

Summary of U-Pb geochronology from data in Table 3, in Appendix

\begin{tabular}{|c|c|c|}
\hline Sample number & Age $(\mathrm{Ma})$ & Unit and description \\
\hline A. $\mathrm{M}-5-88$ & $469 \pm 2$ & Joslin Turn pluton; tonalite \\
\hline B. NH/Mi 1-84 & $468 \pm 3$ & Cambridge Black pluton; biotite granite \\
\hline C. NH/Mi 2-84 & $467 \pm 4$ & Chickwolnepy intrusions; tonalite \\
\hline D. NH/F 1-85 & $456 \pm 3$ & Scrag granite, Jefferson batholith; biotite granite \\
\hline E. NH/Pcy 1-81 & $454 \pm 4$ & Jefferson batholith; biotite trondhjemite \\
\hline F. NH/Mo $1-84$ & $447 \pm 4$ & Landaff pluton; leucocratic hastingsite granodiorite \\
\hline Gn. VT/G 2-87 & $442 \pm 4$ & Lost Nation pluton, northern site; granite. ${ }^{*} 432,{ }^{*} 435$ \\
\hline Gs. NH/Wh 1-79 & $* 443 \pm 3$ & Lost Nation pluton, southern site; quartz diorite. \\
\hline H. NH/Mo 1-89 & $450 \pm 2$ & Moody Ledge pluton; biotite granite \\
\hline I. M-380-81 & $435 \pm 3$ & Tunnel Brook pluton; biotite granite \\
\hline J. NH/MC 1-85 & $410 \pm 5$ & Fairlee pluton; biotite granite \\
\hline K. NH/Mln 1-81 & $378 \pm 2$ & Umbagog pluton; alkali gabbro border facies \\
\hline L. M-270-83 & $364 \pm 5$ & French Pond pluton; biotite granite \\
\hline M. M-122C-83 & $461 \pm 8$ & Ammonoosuc Volcanics; felsic metatuff \\
\hline N. M-250C-83 & $443 \pm 4$ & Quimby Formation; felsic metatuff \\
\hline
\end{tabular}

${ }^{*}$ Data from sphene; all others are from zircon.

Zartman and Leo (1985), who conducted a reconnaissance $\mathrm{U}-\mathrm{Pb}$ zircon study of several Oliverian plutons (domes) along the Bronson Hill anticlinorium; they concluded that the Oliverian gneisses are $444 \pm 8 \mathrm{Ma}$ in age, possibly excepting Whitefield Gneiss, or pluton. Lyons et al. (1986) determined U-Pb zircon ages of $\sim 443-453$ Ma for six of eight known bodies of the Highlandcroft Plutonic Suite, and they confirmed Eisenberg's (1982) U-Pb zircon determination of about $426 \mathrm{Ma}$ for the East Inlet pluton (Fig. 1, S, north tip of $\mathrm{NH}$ ), of the Second Lake rift (Moench et al., 1999). Our data extend the range of Oliverian ages to $\sim 435-456 \mathrm{Ma}$ (Table 1, D, E, F, H, I) and Highlandcroft ages to 442-453 Ma (Table 1, Gn, Gs). Rankin and Tucker (1999) recently reported an age of $441 \pm 1 \mathrm{Ma}$ for a small granitic Highlandcroft body exposed $\sim 3 \mathrm{~km}$ north of the Lost Nation pluton. Zircons from several Highlandcroft bodies contain inherited radiogenic lead, suggesting derivation from source(s) of $\sim 1.5 \mathrm{Ga}$ crust (Lyons et al., 1986).

Although Holtzman et al. (1996) cited an age of 463 Ma for the Attean pluton, a Highlandcroft body that intrudes the Chain Lakes massif, we accept Lyons and others' age of $443 \pm 4 \mathrm{Ma}$ for the Attean pending supporting data for the much-cited 463-Ma age (e.g., van Staal et al., 1998; Robinson et al., 1998, p. 122).

$\mathrm{U}-\mathrm{Pb}$ zircon ages that are listed in Table 1 (A, B, C, $\mathrm{M}, \mathrm{N}$ ) for the Joslin Turn and Cambridge Black plutons, the Chickwolnepy intrusions, and the Ammonoosuc Volcanics, and volcanics of the Quimby Formation, provide essential dates for our definitions of the Ammonoosuc and Quimby sequences.

Additionally, newly determined $\mathrm{U}-\mathrm{Pb}$ zircon ages of $484 \pm 5 \mathrm{Ma}$ for keratophyre of the Jim Pond Formation (Moench et al., 2000), and $477 \pm 1$ Ma for a tonalite sill that occurs along the Jim Pond-Boil Mountain contact (Kusky et al., 1997), have supplanted Eisenberg's (1982) extremely discordant age of $\sim 520$ Ma for the Boil Mountain-Jim Pond ophiolite. Our Jim Pond age is based on SHRIMP analyses of 17 igneous grains from the keratophyre, plus ages of $\sim 390$ Ma for two metamorphic rims, and an age of $\sim 1075$ Ma for one xenocrystic grain. On the assumption that the xenocrystic grain is not a contaminant, its age suggests derivation of silicic Jim Pond magma from Grenville-age basement. The Acadian metamorphic ages are tentatively interpreted to date contact metamorphism by gabbro related to the Flagstaff Lake plutons, exposed a few kilometers south of the sample site. We also reported a newly determined U-Pb zircon (SHRIMP) age of $465 \pm 6 \mathrm{Ma}$ (Moench and Aleinikoff, 2001) for felsic metatuff exposed in the basalt-dominated Clear Stream Member of the Dixville Formation of Green (1964). The sample site is $10 \mathrm{~km}$ northwest of Errol, New Hampshire (Fig. 2, just north of map B), at the same outcrop that previously yielded a discordant lower intercept age of $434 \pm 8$ Ma. This new age determination confirmed Green's correlation of the Clear Stream Member with the Ammonoosuc Volcanics, and it removed the PiermontFrontenac allochthon from a large part of northeastern New Hampshire (see captions for Figs. 2 and 4).

\section{Stratigraphy of the Bronson Hill belt}

Early Silurian and older stratified and plutonic units of the Quimby and Ammonoosuc sequences and their foundations, described below, are exposed along, and just west of, the Bronson Hill anticlinorium (Fig. 2; BHA) northeast of the 44th parallel about $200 \mathrm{~km}$ to where the BHA branches farther northeast to the Lobster Mountain anticlinorium (LMA), and north to the core of the Boundary Mountains anticlinorium (BMA). These sequences, schematically represented in Fig. 3, are 
unconformably overlain by rather thin near-shore Silurian deposits (Figs. 2 and 3, Sns) along the Bronson Hill belt, but from place to place they are both conformably overlain and faulted against far thicker Silurian successor basin deposits (Fig. 3, Sb) of the Central MaineMatapedia and Connecticut Valley-Gaspé troughs (Figs. 2 and 3, CMMT, CVGT). All of these sequences are conformably to unconformably overlain by the Lower Devonian cover sequence (Fig. 3; Dc). Description of the Silurian near-shore and basin deposits and the Lower Devonian cover sequence is beyond the scope of this paper.

\subsection{Neoproterozoic(?) Chain Lakes massif (Fig. 3, unit 1)}

The Chain Lakes massif forms the core of the Boundary Mountains anticlinorium and is exposed in blocks of similar high-grade metamorphic lithology at three other localities in ophiolitic melanges along the Baie Verte-Brompton line (Cousineau, 1991; Malo et al., 1992, pp. 1268-1270; Fig. 1, RP, MS, N). These rocks represent basement of our terrane 1 , which is the Boundary Mountains terrane of Boone and Boudette (1989); also termed the Chain Lakes terrane (Skehan and Rast, 1995). The massif and correlative blocks have a complex metamorphic history, but they occur in otherwise greenschist-facies settings. The rocks are mainly poorly stratified metasedimentary granofelsmatrix polymictic diamictite, and locally abundant mafic plutonic rocks. They are divided into several facies described elsewhere (Moench et al., 1995, pamph. pp. 31, 32; Boudette et al., 1989). Cousineau (1991) described Chain Lakes blocks in the Riviere des Plante ophiolitic melange of the Saint-Daniel Formation (Fig. 1, RP). The diamictite of the massif contains variably abundant angular to subrounded pebbles of veinquartz and pebbles to $1.5-\mathrm{m}$ boulders of mafic and felsic plutonic rocks, volcanic rocks, previously deformed sedimentary rocks, and polycyclic breccia, all supported by a matrix of massive quartz-feldsparmica granofels having a grain size of $\sim 1-2 \mathrm{~mm}$. Well stratified parts contain granofels, quartz-feldspathic gneiss, laminated amphibolite, and meta-arkose. Plutonic rocks are massive, medium- to coarse-grained epidiorite composed of plagioclase and green to brown hornblende.

Geophysical studies suggest that the massif is a subhorizontal tabular body about $4 \mathrm{~km}$ thick, and is either depositionally or structurally directly underlain by Grenville-age basement gneiss (Stewart et al., 1993). The known map distribution of the Chain Lakes indicates that it is a clastic sheet that is caught between the SEdipping hangingwall of the Baie Verte-Brompton suture and the SE-dipping footwall of the Boil Mountain suture (Fig. 1). This relationship suggests that the Chain Lakes is allochthonous. We speculate that the subhori- zontal Chain Lakes-Grenville contact is the Baie VerteBrompton suture. The age and origin of the massif remain enigmatic, and even the suggestion that it might be the remains of an impact structure (Boudette and Boone, 1982) has not been ruled out. Although the massif was long considered to be Mesoproterozoic in age, Dunning and Cousineau (1990) found that the body at Riviere des Plante contains detrital zircon grains as old as $2708 \mathrm{Ma}$ and as young as $571 \mathrm{Ma}$ (Neoproterozoic). We assume a Late Neoproterozoic age for the Chain Lakes.

Additional questions remain about whether the massif is a basement massif; whether its rocks were regionally metamorphosed at high grade before or during emplacement of the structurally overlying Boil Mountain Complex (Boone and Boudette, 1989), or later contact metamorphosed by adjacent Ordovician and Devonian plutons (Trzcienski et al., 1992). Although Trzcienski et al. (1992) claimed that the main body is not a massif, their description (p. 513) of penetrative fabric seen only near the contacts with the surrounding rocks indicates that the Chain Lakes behaved as a structural buttress - a massif by definition. The massif must have been locally metamorphosed by the Late Ordovician ( $443 \pm 4 \mathrm{Ma}$ ) and Devonian $(373 \pm 2,368 \pm 2 \mathrm{Ma})$ plutons that intrude it (see Moench et al., 1995, sheet 2), but the presence of matrix-sillimanite in Chain Lakes blocks at the Riviere des Plante occurrence in Quebec (Cousineau, 1991, p. 86), an area of ambient greenschist-facies metamorphism far from known Ordovician or younger intrusions, supports Boone and Boudette's (1989) interpretation that the massif and the Riviere des Plante blocks are remnants of regionally metamorphosed basement. According to Boudette (1982), the Boil Mountain Complex was thrust onto the Chain Lakes by high temperature ductile faulting, probably while the ophiolite was still hot. This obduction probably occurred at 480-475 Ma and may have been responsible for the regional metamorphism of the Chain Lakes rocks.

But is the Chain Lakes is an exotic microcontinental fragment? The massif has a Grenville-like feldspar leadisotope signature (Ayuso and Bevier, 1991, Fig. 2), and its detrital zircon grains have a wide range of $\mathrm{U}-\mathrm{Pb}$ ages, mainly $1005-1841 \mathrm{Ma}$, but as old as $2708 \mathrm{Ma}$ and as young as $571 \mathrm{Ma}$ (Dunning and Cousineau, 1990), that are consistent with a Laurentian provenance. The youngest age is similar to the $\mathrm{U}-\mathrm{Pb}$ zircon upper intercept age of $571 \pm 5 \mathrm{Ma}$ reported by Walsh and Aleinikoff (1999) for metarhyolite from the Pinney Hollow Formation, Vermont, and other ages in the range of 554-602 Ma in the northern Appalachians from volcanics and intrusives involved in Late Neoproterozoic Iapetan rifting (Walsh and Aleinikoff, 1999, pp. 164 165). These relationships, together with the apparent position of the Chain Lakes above Grenville basement (Stewart et al., 1993), indicate a Laurentian provenance, 
and a permissive Iapetan rift setting, as suggested by Cousineau (1991).

\subsection{Lower Ordovician Boil Mountain complex and ophiolitic melange (Fig. 3, unit 2)}

Units of the ophiolitic sequence include the stratiform mafic-ultramafic Boil Mountain Complex (Fig. 3, Ob), and overlying basaltic and silicic metavolcanic rocks and resedimented volcanics of the Jim Pond Formation $(\mathrm{Oj}$, Ojm), forming plutonic and volcanic members of the ophiolite. Overlying melange of the Hurricane Mountain Formation $(\mathrm{Oh})$ structurally incorporates rafts and slices derived from the Boil Mountain and Jim Pond.

As described by Boudette (1978, 1982), the Boil Mountain Complex is composed (in ascending order) of serpentinized harzburgite-lherzolite, pyroxenite, and epidiorite-gabbro. He tentatively included a layer of tonalite at the top of the sequence, although he allowed (1982, p. 220) that it is slightly discordant and might not properly belong to the ophiolite. Boudette's caution is justified by Kusky et al.'s (1997) U-Pb zircon age of $477 \pm 1 \mathrm{Ma}$ for the tonalite, which is younger than our age of $484 \pm 5 \mathrm{Ma}$ for keratophyre from the overlying Jim Pond Formation (Moench et al., 2000). Both age determinations necessitate revision of the previously assigned age of the Jim Pond Formation from Cambian(?) (Moench et al., 1995), based on a strongly discordant age of $\sim 520$ Ma (Eisenberg, 1982), to Early Ordovician (Ibexian).

At the only known place where Boil Mountain rocks are in undisturbed contact with the overlying Jim Pond Formation, a transition from epidiorite to greenstone occurs, with possible repetitions, within the space of about $150 \mathrm{~m}$. The basal greenstone member of the Jim Pond is $150-500 \mathrm{~m}$ thick, but divided into lower and upper greenstone units by a layer of laterally gradational metadacite and metagraywacke. The greenstone (chlorite-albite-epidote-actinolite) is interstratified with minor amounts of metamorphosed mafic graywacke, dacite, maroon phyllite, and hematitic chert; it is thickly layered, abundantly pillowed, and locally contains thin layers of lapillite. The overlying dacite member of Boudette (1982, p. 222) is $0-500 \mathrm{~m}$ thick; in addition to metadacite, it contains metamorphosed sodic quartzlatite flow rock, ash-flow rock, breccia, epiclastic rock, and iron-formation.

The Boil Mountain-Jim Pond ophiolite is thinner (maximum $\sim 3 \mathrm{~km}$ ) than most ophiolites; it also lacks a well-developed sheeted dike component and it contains unusually abundant felsic volcanics. On the basis of geochemical data, Coish and Rogers (1987) divided the metabasalts into a lower group akin to suprasubduction zone basalt, and an upper group akin to MORB.

The Hurricane Mountain Formation (Fig. 3, Oh), structurally above the Jim Pond (Boone et al., 1989, p.
80 ), is about $1 \mathrm{~km}$ thick. It is composed largely of lightto dark-gray, variably sulfidic, semipelitic phyllite with abundantly scattered sliver-shaped metasedimentary endogenous clasts and a wide variety of endogenous and exotic clasts (Boone et al., 1989, pp. 45-48). Scaly cleavage is characteristic (see Boone and Boudette, 1989; Boudette et al., 1989; Boone et al., 1989; for further descriptions).

The Hurricane Mountain Formation is here reassigned an Early Ordovician age on the basis of its structural position above and lateral to the newly redated Lower Ordovician Jim Pond Formation, and below the lower Middle and Lower Ordovician Dead River Formation, discussed later. The previous assignment of the Hurricane Mountain to the Cambrian was partly based on the occurrence of primitive sponge fragments recovered by Harwood (1973) from the upper part of the Hurricane Mountain. Although R.M. Finks, who examined the fossils, favored a Cambrian age, he did not rule out an Ordovician age for these forms (written commun. to D.S. Harwood, 1964, and oral communs. to Moench, 1982, 1983). Whether the sponges (Protospongia sp.) are Cambrian or Ordovician may not be relevant, however, because, according to Finks' communications, sponges require a quiet oxygenated marine environment that seems to be at odds with the probably tectonically active, euxinic environment of Hurricane Mountain deposition. According to Finks, similar forms occur at Metisse sur Mer on the northwest shore of the western Gaspé, Quebec; accordingly it seems likely that the black slate that hosts the spicules slid from the Laurentian margin during Hurricane Mountain deposition.

Boone et al. (1989) reported apparent ${ }^{40} \mathrm{Ar} /{ }^{39} \mathrm{Ar}$ hornblende ages of $\sim 485 \mathrm{Ma}$ for metagabbro that they reported to intrude the Hurricane Mountain, and $\sim 540$ Ma for a megaclast in the Hurricane Mountain. Whereas $485 \mathrm{Ma}$ might represent the time of emplacement of Jim Pond gabbro during an early stage of melange formation, the earliest Cambrian age for the megaclast might represent metamorphism during the rift-drift phase of the pre-Iapetan Laurentian margin, long before the clast was eroded from the margin and carried to the trench. However, the rifting is only approximately constrained between 554 and 571 Ma (Walsh and Aleinikoff, 1999).

\subsection{Lower Middle and Lower Ordovician flysch (Fig. 3, unit 3)}

Boone (1973) defined the Dead River Formation for exposures of polydeformed, thinly interbedded slate and wacke that overlie the Hurricane Mountain Formation in the Little Bigelow Mountain and Pierce Pond 15-min quadrangles, western Maine. As shown in Fig. 2, the Dead River, together with distinctly 
more pelitic rocks mapped as the Aziscohos Formation (Green, 1964), comprise a flysch sequence that has been mapped nearly to the southwest corner of the Lewiston $1^{\circ} \times 2^{\circ}$ quadrangle. The Aziscohos is here considered a pelitic facies of the Dead River. The flysch is composed of planar bedded turbidites. Its quartzites and quartzwackes are typically well graded; "pinstripe lamination" parallel to bedding is common but not ubiquitous. The graded bedding styles are very comparable to those of the Moretown Member of the Missisquoi Formation of north-central Vermont. The sequence is about $700 \mathrm{~m}$ thick in the type area of the Dead River Formation, where it is unconformably overlain by less-deformed Silurian beds (Boone, 1973). In the Oquossoc, Milan, and Littleton areas farther south, where the Dead River is abruptly but conformably overlain by the Ammonoosuc Volcanics and locally by the Partridge Formation, the flysch may be as thick as $1 \mathrm{~km}$.

The Dead River Formation is here assigned an early Middle and Early Ordovician age, based on its position (along with the underlying Hurricane Mountain Formation) above the Lower Ordovician Jim Pond Formation and below the Middle Ordovician Ammonoosuc Volcanics (Table 1). Specifically, uppermost Dead River beds are no younger than the 469 Ma Joslin Turn pluton. Because the Joslin Turn is probably coeval with basal volcanics of the Ammonoosuc, as discussed later, the uppermost beds of the underlying Dead River are probably early Middle Ordovician in age.

The flysch, interpreted as deep marine deposits, has an important mafic igneous provenance, as shown by chemical analyses of Dead River metashale compared to typical North American shale (Boone, 1973) and analyses of Dead River metashale compared to metashale from the Silurian Perry Mountain and Rangeley Formations (Moench, unpub. data). Dead River metashales have significantly higher $\mathrm{Fe}$ and $\mathrm{Mg}$ and lower $\mathrm{Al}$ contents, and distinctly lower $\mathrm{K} / \mathrm{Na}$ ratios. According to Boone, the flysch was deposited as a "carapace" over the Hurricane Mountain Formation after the melange became inactive.

In New Hampshire and along the ME-NH border, the flysch sequence, except the Aziscohos, was originally mapped by several geologists as the Albee Formation, a name that is not used herein (but is still retained by Rankin (2001)) because large parts of the Albee of its type area on Gardner Mountain (Billings, 1937) and nearby strike belts (Fig. 4C) have been remapped and reassigned to eight units of mainly Silurian age of the Piermont-Frontenac allochthon (Moench, 1990, 1996a, 1999). Discussion of the allochthon is beyond the scope of this paper, but readers are referred to Moench (1999) for distinctions between rocks now mapped as Dead River and those reassigned to the somewhat similar Silurian Perry Moun- tain Formation. Conclusive evidence for the existence of the allochthon is given by a newly determined $\mathrm{U}-\mathrm{Pb}$ zircon (SHRIMP) age of $437 \pm 6 \mathrm{Ma}$ (Llandovery) (J.N. Aleinikoff, unpub. data) for rhyolite-bearing debris-flow deposits of uppermost Rangeley Formation, conformably below Perry Mountain beds. The locality is a roadcut on US 5 , about $1 \mathrm{~km}$ northeast of the center of Bradford village, $\mathrm{Vt}$.

\subsection{Middle Ordovician Ammonoosuc sequence (Fig. 3, unit 4)}

The Ammonoosuc sequence is here named for exposures of the Ammonoosuc Volcanics, the Partridge Formation, and the Joslin Turn and Cambridge Black plutons and Chickwolnepy intrusions along and just west of the Bronson Hill anticlinorium north of $44^{\circ} \mathrm{N}$. The Quimby area (Fig. 4A) is primarily an area of greenschist facies metamorphism north of Rangeley and Mooselookmeguntic Lakes, plus hornfels adjacent to the large Devonian plutons, and greenschist to staurolite zone metamorphism to the southeast. There is a narrow band of sillimanitic rocks adjacent to the east side of the Mooselookmeguntic batholith (Fig. 4A; Dn1).

The Milan area (Fig. 4B) is at the very northeastern tip of the Jefferson batholith (SO9), which cores the largest Oliverian dome of the Bronson Hill anticlinorium. Metamorphic facies range from lower to middle amphibolite in a wide belt around the batholith, to greenschist northwest of the Chickwolnepy intrusions $(\mathrm{O} 2)$.

The Littleton area (Fig. 4C) contains a large part of the Littleton-Moosilauke area of Billings (1937), where he defined what soon became known as the classic New Hampshire sequence: (in ascending order) the unfossiliferous but presumed Ordovician Albee Formation, Ammonoosuc Volcanics, and Partridge Formation, the locally fossiliferous Lower Silurian Clough Quartzite, and the fossiliferous Upper Silurian Fitch Formation, and Lower Devonian Littleton Formation. The mapping shown in Fig. 4C combines the work of Billings and his colleagues, and extensive revisions by Moench and his associates from 1981 to 2000 . Readers are referred to Rankin (1996) and Moench (1996a, 1999) for discussion of controversies involving the later work.

The Littleton area is diagonally crossed by the Ammonoosuc fault (AF), originally mapped as a westdipping thrust fault (Billings, 1935) but now generally acknowledged to be one of the major Triassic normal faults of central New England (Lyons et al., 1997); it extends at least $200 \mathrm{~km}$ from northern New Hampshire southwest to Springfield, Vermont. In the Littleton area, the AF separates a low grade (greenschist facies) hanging wall block on the northwest from a higher grade (upper greenschist to middle amphibolite facies) block on the southeast. Based on an average northwesterly dip 
of about $40^{\circ}$ and down-dip lineations, structure sections (R.H. Moench, unpub. data) indicate that the hangingwall block dropped about $4 \mathrm{~km}$ in the Littleton area. Greater amounts of displacement are inferred to the southwest (see structure sections in Moench, 1996a, Fig. 5; Moench, 1990, Figs. 2 and 3). Accordingly, the AF provides a stratigraphic and structural view of the area at two crustal levels. For example, when restored without the AF, the Lost Nation and Highlandcroft plutons (Fig. 2, SO6, SO8), northwest of the AF, become the downthrown former cap of the Whitefield pluton (SO7), southeast of the AF. Similarly, the Walker Mountain and Salmon Hole Brook synclines (WMS, SHBS) and the Tinkerville and Lisbon synclines (TS, LS) are seen to be the same structures. Although Triassic displacement is assumed, several earlier displacements may have occurred.

\subsubsection{Ammonoosuc Volcanics and Partridge Formation}

Billings (1935, p. 10) named the Ammonoosuc Volcanics (Oa) for exposures of metamorphosed volcanic rocks along the Ammonoosuc River between Littleton and Bath, NH, east of the Ammonoosuc fault, but he designated about $5 \mathrm{~km}^{2}$ of area, west of the fault, between the Highlandcroft pluton (Fig. 4C, SO8) and the east limb of the Partridge Lake syncline, to represent the type area of the Ammonoosuc. Billings named the Partridge Formation for black slate exposed along the Partridge Lake syncline (Fig. 4C, PLS). According to Billings (1935), the type Partridge of this belt conformably overlies the type Ammonoosuc. Graded beds observed by Moench at two localities on the east limb of the Partridge Lake syncline, and at one locality on the west limb, confirm Billings' interpretation that the type Partridge in fact overlies the type Ammonoosuc.

3.4.1.1. Distribution and lithologic descriptions. The Ammonosuc of the Littleton area (Fig. 4C) is exposed at high metamorphic grade: (1) along the Bronson Hill anticlinorium (BHA), where it is intruded by granitic plutons of the Oliverian domes (Ammonoosuc of the domes), and (2) from the area of Littleton village, south to the limbs of the Lisbon syncline (LS). At low metamorphic grade, northwest of the Ammonoosuc fault, the Ammonoosuc occurs: (1) in the Moore Reservoir area on both limbs of the Partridge Lake syncline; and (2) in the Coppermine Road window, west of Gardner Mountain. Except for metamorphic grade, there is no major lithologic difference between the Ammonoosuc of these four main belts. The Partridge Formation, composed largely of jet-black, sulfidic slate or schist, is well exposed at low grade along the troughline of the Partridge Lake syncline, and at high grade along the limbs of the Lisbon syncline. It is absent in the window, and was found, in association with Ammonoosuc of the domes only in a narrow belt about $3 \mathrm{~km}$ long south of the area of Fig. $4 \mathrm{C}$.

The thickness of the Ammonoosuc of the Littleton area probably ranges from about $200 \mathrm{~m}$ west of Moore Reservoir to more than $1 \mathrm{~km}$ along the BHA. West of the anticlinorium it thins to nil approximately midway between the Littleton and Milan areas. Although the Ammonoosuc of the Littleton area has not been studied in stratigraphically controlled petrochemical detail, primary volcanic features are well exposed, and reasonable estimates of composition can be made from color and mineral composition-white to pale gray color with quartz-bearing feldspathic (plagioclase) composition being metamorphosed probable keratophyric sodarhyolite or dacite; dark greenish-gray to black with chlorite- or hornblende-rich compositions being basalt or basaltic andesite.

In most of the Littleton area, the Ammonoosuc is a stratigraphically complex assemblage of mixed, commonly massively bedded, fine- to coarse-grained, proximal, mafic to felsic volcanics intruded by many small bodies of hypabyssal trondhjemite or tonalite and gabbro. Moench et al. (1995) have divided the Ammonoosuc of the Littleton area into facies that include basaltic volcanics, proximal volcanics of mixed composition, felsic tuff, sedimentary and minor basaltic volcanics, volcaniclastic graywacke, hydrothermally altered pyritic quartz-muscovite schist, and, locally, varieties of ironformation (layered magnetite, pyrite, and iron-rich silicates). The basaltic facies contains pillowed and massive flows, tuff, hyaloclastites, bouldery agglomerate, and fine-grained mafic sedimentary rocks. It lies near the base of the Ammonoosuc, but it grades laterally to, and is overlain by, the proximal mixed volcanic facies; hyaloclastite amphibolite locally occurs directly under the Partridge Formation. The proximal mixed volcanic facies contains interlayered felsic and mafic rocks (probably mainly metatuff), and thick sequences of massive, very thick, poorly graded beds of tuff-matrix cobbly to bouldery volcanic conglomerate and pyroclastic-flow deposits. These rocks grade northward to fine-grained distal mixed volcanics, exposed mainly north of Moore Reservoir. The pyritic quartz-muscovite schist is an unstratified mixture of muscovite schist and thin lenses of white, sugary quartz; pyrite is abundantly disseminated and pinpoints of chalocopyrite are common. This rock is interpreted as hydrothermally altered tuff, probably representing stratiform alteration associated with sea-floor VMS mineralization (Moench et al., 1999, and references therein). Other features of premetamorphic hydrothermal alteration and evidence of VMS mineralization in the Littleton area are described by Moench et al. (1999), who assign the area a high potential for the occurrence of VMS deposits in the Ammonoosuc of both the Littleton and Milan areas (Fig. $4 \mathrm{C}$ and $\mathrm{B}$ ), but not the Oquossoc area, where the entirely 
basaltic Ammonoosuc contains no recognized evidence of mineralization.

The Partridge Formation of the Littleton area is 0 $200 \mathrm{~m}$ thick; it lies conformably above the Ammonoosuc. It is composed largely of rusty-weathering, sulfidic, jetblack slate or schist. Stream-washed pavement outcrops show repeated "slow-graded" beds of metasiltstone or metagraywacke to pelitic slate. Thin graded beds of felsic metatuff locally occur at the upper and lower contacts, and thin beds of white, sugary orthoquartzite, interpreted as metamorphosed chert, are common near the lower contact, particularly along the west limb of the Lisbon syncline. On the east limb of the syncline, laminated beds of silicate iron-formation, now composed of quartz, garnet, chlorite, and locally spectacular sunbursts of gedrite, occur in a transition zone to the underlying Ammonoosuc.

The main body of Ammonoosuc in the Milan area (Fig. 4B) has an estimated thickness of about $1 \mathrm{~km}$. It contains most of the rock assemblages that are exposed in the Littleton area, but a lower basaltic member is more clearly separated from an overlying proximal mixed volcanic member that grades laterally to, and is overlain by, pyritic quartz-muscovite schist, and a volcaniclastic sedimentary facies. The latter is associated with silicate iron-formation (quartz-magnetite-garnetchlorite-biotite gneiss) with local quartz-kyanite gneiss. Basaltic and soda-rhyolitic compositions are abundantly demonstrated petrographically and chemically (Fitz, 1999; Moench, unpub. data). A small polymetallic Kuroko-type VMS deposit at the Milan mine is hosted by the proximal mixed member, just above the basalticmixed volcanic contact; a possibly important Besshitype copper deposit at the Hampshire Hills prospect is hosted by the volcaniclastic sedimentary and silicate iron-formation facies. These deposits and other evidence of volcanogenic mineralization are described by Moench et al. (1999).

Richly pyrrhotitic black schist of the Partridge Formation is only locally associated with the main body of Ammonoosuc (Fig. 4B), and is absent along the apparently unconformable Ammonoosuc-Quimby contact of this area. A small body of Partridge is exposed at the base of the Ammonoosuc about $6 \mathrm{~km}$ east of the area of Fig. 4B (see Moench et al., 1995). Within the Rice Mountain syncline, however, Partridge is abundant; there it intertongues with the Ammonoosuc (Fig. 4B, RMS).

The Ammonoosuc Volcanics of the Rice Mountain syncline (Fig. 4B, RMS) is as much as $650 \mathrm{~m}$ thick, and occurs mainly as lenses of massive and pillowed basaltic amphibolite within a matrix of black schist. A small amount of felsic metatuff occurs above the metabasalt. As already cited, Moench and Aleinikoff (2001) have recently redated one body of felsic lapilli metatuff at $465 \pm 6 \mathrm{Ma}$; the locality is $10 \mathrm{~km}$ northwest of Errol,
NH (Fig. 2). At the southern "heel" of the syncline, a lens of polymictic pebble-cobble metaconglomerate is interstratified with cherty iron-formation and metabasalt in the basal $100 \mathrm{~m}$ of the Ammonoosuc. Here, massive and graded beds of the conglomerate contain rounded to angular pebbles and cobbles of volcanics and sedimentary rocks, granite, and gabbro supported by a matrix of volcaniclastic grit. Planar beds of metamorphosed chert and cherty iron-formation having variable abundances of magnetite and spessartine are common in the Ammonoosuc of the syncline. Petrochemically, the metabasalts of the syncline are comparable to the tholeiitic supra-subduction metabasalts of the main Ammonoosuc body to the southeast (Fitz, 1999, 2002; Moench, unpub. data).

The Ammonoosuc of the Oquossoc area (Fig. 4A) is restricted to an entirely basaltic lens as much as $1500 \mathrm{~m}$ thick. Its basaltic composition was recognized by Harwood (1973) and Guidotti (1977) and by Moench (unpub. chemical data). The rocks are dark-green, thickly layered, massive and pillowed basaltic greenstone, locally containing thin agglomeratic beds. The basaltic lens tongues northward into, and is overlain by, black slate of the Partridge Formation, which has a possible total thickness of $2 \mathrm{~km}$, as measured between the underlying Dead River Formation and the overlying Quimby Formation. Although Harwood and Guidotti originally mapped both units as members of the Dixville Formation, Moench et al. (1995, pp. 29, 43) reassigned them to the Ammonoosuc Volcanics and Partridge Formation, respectively. The Partridge of the Oquossoc area is composed mainly of rusty-weathering black slate, but it contains sparse metamorphosed graywacke, impure quartzite, polymictic conglomerate, and thin lenses of basaltic greenstone. The upper $150 \mathrm{~m}$ of the Partridge is thinly interbedded metagraywacke and black slate forming a transition to the overlying Quimby Formation.

3.4.1.2. Nature of lower contacts. In all three areas the contact between the Ammonoosuc Volcanics and the underlying Dead River Formation is sharp or gradational within the space of about $1 \mathrm{~m}$. Graded beds, observed at one locality in the Milan area and at several localities west of Moore Reservoir in the Littleton area, indicate that the Dead River is overlain by the Ammonoosuc.

Where the Partridge Formation is in direct contact with the Dead River, without intervening Ammonoosuc, the contact is similarly abrupt and probably conformable.

3.4.1.3. Age. Fig. 4A shows two Ordovician fossil localities in the Partridge Formation, plotted from Harwood (1973). The northern locality is the site of lower Mohawkian C. bicornis zone graptolites (Harwood and 
Berry, 1967) that date the portion of the Partridge Formation that overlies the Ammonoosuc Volcanics. The fossils were found $\sim 300-400 \mathrm{~m}$ above the contact. The southern locality yielded Scoto-Appalachian brachiopod fragments that do not give a precise age (Neuman et al., 1989, site O-6a). An age of $\sim 457 \mathrm{Ma}$ is appropriate for the graptolites and early Mohawkian time. Accordingly, the upper boundary of the Ammonoosuc greenstone body is probably no younger than about $458 \mathrm{Ma}$, which is consistent with the $\mathrm{U}-\mathrm{Pb}$ zircon age of $461 \pm 8 \mathrm{Ma}$ for probable uppermost felsic Ammonoosuc from the Bronson Hill anticlinorium south of Littleton (Table 1). The lower contact of the Ammonoosuc is intruded by the Joslin Turn pluton of the Littleton area, and the Chickwolnepy intrusions and Cambridge Black pluton of the Milan area, which yielded U-Pb zircon ages of 469-467 Ma (Table 1). Because only the youngest tonalite body of the Chickwolnepy was dated (Fitz, 2002), the Chickwolnepy intrusions as a whole may have a maximum age that is at least as old as the Joslin Turn pluton. As discussed later, both the Chickwolnepy and Joslin Turn are hypabyssal bodies that may be comagmatic with some of the earliest Ammonoosuc eruptions.

3.4.1.4. Correlations on strike to the south. Lyons et al. (1997) divided the Ammonoosuc Volcanics of the Littleton area into a lower part here considered the Ammonoosuc of the Ammonoosuc sequence, and an upper part here considered the Quimby Formation of the Quimby sequence. The lower Ammonoosuc of their map is shown to extend south along the BHA all the way to the Massachusetts border area. There, Schumacher (1988) divided the Ammonoosuc into a lower member composed mainly of hornblende amphibolite with lenses of marble and skarn, gedrite gneiss, and felsic gneiss; a medial garnet-amphibole-magnetite quartzite member (metachert); and an upper member composed of quartzfeldspar-biotite gneiss, aluminous schist and gneiss, and amphibolite. He proposed (p. 633) that the medial member "may be evidence of chemical sedimentation of ferruginous and locally manganiferous cherts that occurred as the chemical character of the volcanism underwent a major change". Tucker and Robinson (1990) obtained Late Ordovician U-Pb zircon ages of $453 \pm 2$ Ma from quartz-phyric rhyolite from the upper member, and $449+3 /-2$ Ma from metarhyolite tuff from the overlying Partridge Formation; the lower member of their Ammonoosuc remains undated. We propose that the lower member belongs to our Middle Ordovician Ammonoosuc sequence, whereas their dated upper Ammonoosuc and the overlying Partridge are approximately equivalent to our volcanic and graywacke and shale members of the Quimby Formation. Their medial member, moreover, may be approximately coeval with the type Partridge - specifically with the metachert beds and silicate iron-formation at the base of the Partridge of the Lisbon syncline (Fig. 4C).

3.4.1.5. Correlations across strike to the west. In Vermont, Karabinos and coworkers (Karabinos and Tucker, 1992; Karabinos and Thompson, 1997; Karabinos et al., 1996, 1998) have recently defined the Ordovician Shelburne Falls arc (Fig. 1, SFA), extending 185 $\mathrm{km}$ from central Vermont to western Connecticut. The main units of the SFA are the Barnard Volcanic Member of the Missisquoi Formation, as mapped by Doll et al. (1961) in Vermont, and the Hawley Formation in Massachusetts (Kim and Jacobi, 1996); other named units occur in isolated bodies. These units form a belt of strongly deformed and metamorphosed mafic and felsic plutonic rocks and interstratified volcanic and sedimentary rocks that are dated in the range of 471-475 and $485 \mathrm{Ma}$ (Karabinos et al., 1998, Fig. 1). Boninitic amphibolites of fore-arc affinity are recognized (Kim and Jacobi, 1996), and the Moretown Member of the Mississquoi, the principal sedimentary unit of the package, is interpreted as a fore-arc basin deposit having a Laurentian provenance (Karabinos and Gromet, 1993).

The ages of the Shelburne Falls arc (SFA) are slightly older than our ages for intrusives of the Ammonoosuc sequence (Table 1), but the oldest SFA age is indistinguishable from the Jim Pond age of $484 \pm 5 \mathrm{Ma}$ (Moench et al., 2000). These data and the striking similarity of the Dead River Formation and Moretown Member suggest that the SFA and the Jim Pond to Ammonoosuc sequence are reasonable correlatives. However, whereas Jim Pond to Ammonoosuc is a clearly defined succession, it remains to be determined whether or not a comparable succession occurs in the SFA. Tentatively, however, we assume that SFA and Jim Pond to Ammonoosuc are parts of the same package of suprasubduction volcanics and flysch.

In Quebec, arc-magmatic rocks of the Ascot Complex, exposed in the Weedon and Sherbrooke areas, contain basaltic and felsic volcanics and related schists, volcaniclastic rocks, mafic-ultramafic and tonalitic intrusives, and a large pluton of synvolcanic granite (Tremblay et al., 1995, p. 183; Tremblay et al., 2000). Rhyolite that hosts the granite has yielded a $\mathrm{U}-\mathrm{Pb}$ zircon age of $460 \pm 3 \mathrm{Ma}$ (David et al., 1993) and the granite itself has yielded ${ }^{39} \mathrm{Ar} /{ }^{40} \mathrm{Ar}$ muscovite cooling age of 462 Ma (Tremblay et al., 2000). David and others also reported a U-Pb zircon age of $441+6 /-8 \mathrm{Ma}$ for a separate rhyolite body. These ages are consistent with our ages of $461 \pm 8$ and $443 \pm 4 \mathrm{Ma}$ for the Ammonoosuc Volcanics and the Quimby Formation, but more data are needed before these correlations are accepted.

The St. Victor synclinorium, northwest of the Ascot Complex, contains the mainly sedimentary Magog 
Group, considered to have accumulated in a fore-arc basin (Cousineau, 1994). Correlation of the Partridge Formation with graptolite-bearing upper parts of the Magog was established long ago by the occurrence of zone 12 graptolites in both units (Berry, 1962; Harwood and Berry, 1967). As summarized by Cousineau and St. Julien (1992) and Tremblay et al. (1995, Fig. 3.105, pp. 183-185), the Magog is divided into (ascending) the Frontière Formation (unfossiliferous interbedded green feldspathic, volcanogenic sandstone and mudslate); the Etchemin Formation (unfossiliferous black and green mudslate, siliceous mudrock with some felsic to intermediate volcaniclastic beds in its upper part); the Beauce-ville Formation (mainly black graphitic slate with numerous beds of felsic submarine pyroclastic flow deposits, and containing Whiterockian and lower Mohawkian graptolites); and the Saint-Victor Formation, comprising $70 \%$ of the Magog (dark-gray turbidites with a few felsic volcaniclastic beds and containing Mohawkian graptolites).

On the assumption that the undated Frontière and Etchemin Formations are approximately coeval with the Dead River Formation and immediately overlying volcanics of basal Ammonoosuc of the Littleton to Oquossoc areas, these units are reasonably correlated.

3.4.1.6. Correlations in northern Maine. The Ammonoosuc may correlate to the Kennebec Formation, exposed west of Moosehead Lake in a small area in the Lobster Mountain anticlinorium (Fig. 1; LMA). The Kennebec, composed of quartz-porphyritic rhyolite tuff and felsite, contains a Middle Ordovician brachiopod fauna (Boucot, 1969, pp. 54, 55) having an Appalachian association that is unlike northern European forms (Boucot, 1973, p. 3). Neuman (1984, Fig. 2) placed the age of the brachiopods on the Llanvirn-Llandeilo boundary, or squarely Middle Ordovician. On the smallscale maps of Osberg et al. (1985) and Boone et al. (1989, Fig. 1), the Kennebec is confined to a northeast-trending lens (about $1 \times 7 \mathrm{~km}$ ) that is bounded, except where faulted, by the Hurricane Mountain Formation. Boone et al. (1989, p. 61, and references therein) have inferred that the Kennebec is gradationally overlain by the Lobster Mountain Volcanics. However, the disparate ages of these units (representing 10-20 m.y.), and the apparent absence of a mutual Kennebec-Lobster Mountain contact (as shown on the cited small-scale maps), permits the view that deposition of the Kennebec Formation was followed by erosion that preceded deposition of the Lobster Mountain Volcanics. According to Boone et al. $(1989$, p. 61), the Kennebec is unconformably underlain by more strongly deformed rocks of the Dead RiverHurricane Mountain-Jim Pond sequence. A similar relationship at the base of the Ammonoosuc Volcanics is ruled out in the Littleton area, but not necessarily in parts of the Milan and Oquosoc areas.
The Middle Ordovician Ammonoosuc Volcanics and the early Late Ordovician (Mohawkian) Partridge Formation have no certain time-stratigraphic correlatives northeast of the Bronson Hill belt. However, the Partridge, with its $C$. bicornis zone graptolites, is at least partly coeval with the sedimentary Chase Lake Formation, the predominantly basaltic Bluffer Pond Formation, and the predominantly felsic volcanic Munsungun Lake Formation of the Munsungun anticlinorium (Hall, 1970). Although these three units contain C. bicornis, mapping and other fossil assemblages indicate that they occur in an ascending Chase Lake to Munsungun Lake sequence, with lateral facies changes from Chase Lake to Bluffer Pond (Hall, 1970, Plate II). The volcanic Bluffer Pond and Munsungun Lake Formations are too young to be considered correlatives of the Ammonoosuc Volcanics, and the same evidence applies as well farther north to the basaltic Winterville Formation of the Winterville anticlinorium (Roy and Mencher, 1976). Petrochemically, basalts of the Bluffer Pond and Winterville Formations have within-plate minor-element signatures (Winchester and van Staal, 1994), which further argues against their correlation to the Ammonoosuc.

The small Silurian(?) volcano-sedimentary Bald Mountain terrane in the Winterville anticlinorium (Slack et al., 1999) is discussed later under "Contributions of common lead" to delineation of the Red Indian line.

The informally named "Stacyville volcanics" of the Lunksoos anticlinorium of northeastern Maine (Fig. 1; LSA) is regarded by Wellensiek et al. (1990) to be Middle Ordovician in age, on the undocumented assumption (Neuman, 1991, p. 644) that the "Stacyville" is overlain by the Wassataquiok Chert, which contains a Scoto-Appalachian fauna of early Late Ordovician age (Neuman, 1984). According to Neuman (1984, Fig. 2), the Wassataquiok and unnamed volcanics (Stacyville of Wellensiek et al., 1990) may be coeval. If so, parts of the Stacyville may be related to the lower Upper Ordovician Bluffer Pond and Winterville Formations, discussed above; Stacyville basalts also have within-plate signatures (Winchester and van Staal, 1994).

\subsubsection{Chickwolnepy intrusions}

These intrusions and the adjacent Ammonoosuc Volcanics and the Cambridge Black pluton (Fig. 4B) were initially mapped by Moench, Jill L. Schneider, and Jane S. Selverstone, and were later studied in detail by Fitz (1996, 1999, 2002).

As mapped by Fitz, the Chickwolnepy intrusions have a central core of metagabbro, with a small complex of chaotically mixed metagabbro, metadiabase, and metabasalt, swarms of isolated and sheeted metadiabase dikes extending south and north-northwest from the gabbroic core; many small dikelets and rounded lenses 
of trondhjemite associated with the dikes, two bodies of quartz-phyric metatonalite, and one of aphyric metatonalite. The dikes have a strong preferred orientation at $\sim \mathrm{N} 20^{\circ} \mathrm{W}$, about normal to the orogenic trend in the area, and they cut sharply across the Dead RiverAmmonoosuc contact. The aphyric metatonalite, the youngest Chickwolnepy intrusion, yielded a $\mathrm{U}-\mathrm{Pb}$ zircon age of $467 \pm 4 \mathrm{Ma}$ (Table 1); accordingly, basal Ammonoosuc beds may be significantly older.

\subsubsection{Cambridge Black pluton}

The granitic Cambridge Black pluton, considered a Highlandcroft body by Moench et al. (1995), is here included with the Chickwolnepy association on the basis of its age (Table $1 ; 468 \pm 3 \mathrm{Ma}$ ) and its proximity to the Chickwolnepy. Although it intrudes metadiabase dikes of the Chickwolnepy, it is not in contact with the dated tonalite. The pluton is a homogeneous body of foliated, pink-leucocratic, medium-grained, biotite granite having the petrographic and chemical composition of alkalifeldspar granite. This is shown by the following majoroxide analysis of the dated sample: $\mathrm{SiO}_{2}, 76.3 \% ; \mathrm{Al}_{2} \mathrm{O}_{3}$, $12.6 \% ; \mathrm{Fe}_{2} \mathrm{O}_{3}, 1.62 \% ; \mathrm{MgO},<0.10 \% ; \mathrm{CaO}, 0.25 \%$; $\mathrm{Na}_{2} \mathrm{O}, 3.32 \% ; \mathrm{K}_{2} \mathrm{O}, 4.76 \% ; \mathrm{TiO}_{2}, 0.03 \% ; \mathrm{P}_{2} \mathrm{O}_{5},<0.04 \%$; $\mathrm{MnO}, 0.04 \%$; LOI, $0.41 \%$ (analysis by US Geological Survey). The foliation penetrates the pluton in a pattern that is broadly arcuate relative to the northeastern end of the Jefferson batholith (SO9).

The strongly evolved granite of the Cambridge Black pluton is clearly coeval with, but not comagmatic with, the primitive Chickwolnepy intrusions. The heat source

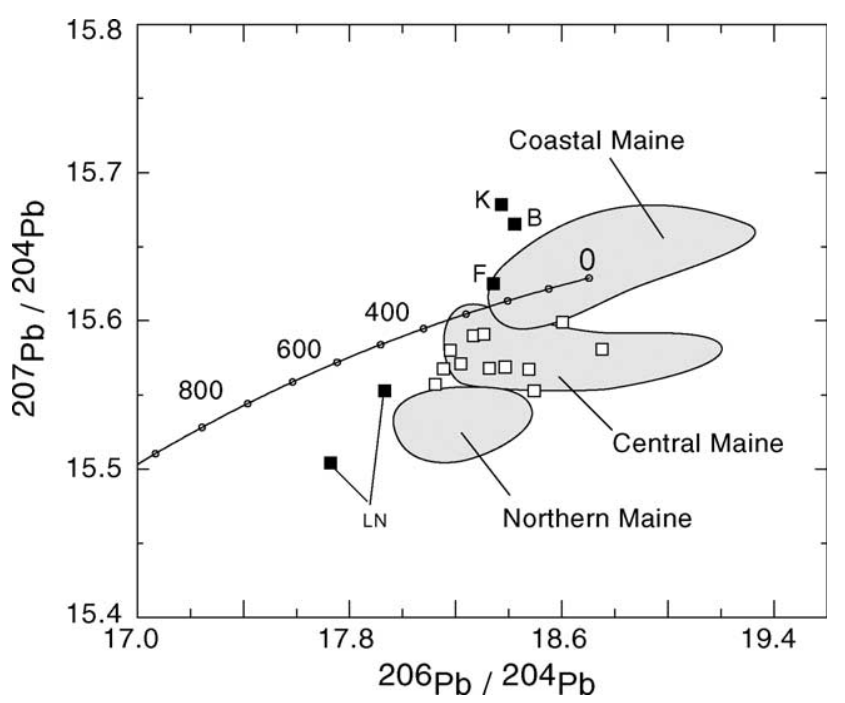

Fig. $6 .{ }^{206} \mathrm{~Pb} /{ }^{204} \mathrm{~Pb}-{ }^{207} \mathrm{~Pb} /{ }^{204} \mathrm{~Pb}$ plot showing lead-isotope compositions of feldspars from granitic plutons of the Bronson Hill anticlinorium, northern New Hampshire and western Maine relative to average $\mathrm{Pb}$ evolution curve of Stacey and Kramers (1975). Shaded fields are from Ayuso and Bevier (1991, Figs. 2, 3, 4). LN, Lost nation pluton; F, Fairlee pluton; B, Bethlehem Granodiorite; K, Kinsman Granodiorite. may have been the basaltic magma now represented by the Chickwolnepy gabbro and sheeted diabase dikes, but the melting source is unclear. Because the feldspar- $\mathrm{Pb}$ isotopic composition of the granite occurs in the intermediate field for central Maine plutons (Fig. 6; Table 2) of Ayuso and Bevier (1991), a source in Grenville-like or Avalon-like basement is unlikely. Alternatively, the source might have been sea-floor flysch (Dead River Formation), but the granite is considerably more evolved than the "flyschmelt" granodiorites of the eastern Gulf of Alaska (Barker et al., 1992).

\subsubsection{Joslin Turn pluton, its offshoots, and trondhjemite intrusions}

The Joslin Turn pluton (Fig. 1, O1; Table 1, 469 \pm 2 $\mathrm{Ma}$ ) is a semiconcordant lens as much as $8 \mathrm{~km}$ long and $400 \mathrm{~m}$ wide, emplaced at a very low angle across the Dead River-Ammonoosuc contact (Fig. 4C, Od, Oa). The pluton is composed of one-feldspar quartz diorite to tonalite containing an estimated $10-20 \%$ quartz, as much as $70 \%$ albite, $10 \%$ green chlorite, subordinate secondary epidote, sparse sericite, and sparse accessory magnetite. Where strongly altered, feldspar is variably replaced by sericite, chlorite, and epidote. The least altered textures are strongly seriate-porphyritic, having interpenetrating albite laths that range from $<1 / 2$ to 3 $\mathrm{mm}$ near the center of the pluton.

According to Rankin (1996), granophyric textures are well preserved in the main body and in some of its offshoots, as well as in some dikes that Moench does not accept as Joslin Turn offshoots (see Moench, 1999, for discussion). Offshoots accepted by Moench are semiconcordant bodies, rarely more than a few meters thick, most of which occur near the Dead River-Ammonoosuc contact. They are composed of resistant, white-weathering, strongly seriate, feldspar-rich tonalite or trondhjemite, commonly having irregular, stringer-like habits that one might expect of a felsic magma that intruded its own tuffaceous pile. Locally associated with these offshoots are small concordant bodies of black, feldsparpoor, partly retrograde hornblende-rich amphibolite and metadiabase. Pending further investigation, this relationship suggests that a petrologic and tectonic relationship exists between the Joslin Turn pluton and its offshoots and the Chickwolnepy intrusions.

The stratigraphic and structural setting and strongly seriate textures (with possible granophyre) of the Joslin Turn pluton and its offshoots suggest that they were emplaced subhorizontally at shallow depth, where they crystallized rapidly. The main body is here interpreted as the upturned edge of a thin laccolith that was emplaced penecontemporaneously with some of the earliest Ammonoosuc eruptions. Heat from the magma is interpreted to have generated a hydrothermal system involving juvenile and/or meteoric fluids that altered and weakly copper-mineralized much of the surrounding 
Table 2

Common lead ratios in feldspars from Paleozoic plutonic rocks of the northern Bronson Hill anticlinorium

\begin{tabular}{|c|c|c|c|c|}
\hline Sample no. & Pluton name & $\mathrm{Pb}^{\mathrm{a}} /{ }^{204} \mathrm{~Pb}$ & ${ }^{207} \mathrm{~Pb}^{\mathrm{a}} /{ }^{204} \mathrm{~Pb}$ & ${ }^{208} \mathrm{~Pb}^{\mathrm{a}} / 204 \mathrm{~Pb}$ \\
\hline NH/Mil-84 & Cambridge Black & 18.221 & 15.571 & 38.109 \\
\hline NH/MI2-84 & Chickwolnepy intrusions & 18.603 & 15.599 & 38.242 \\
\hline NH/F1-85 & Scrag granite of Jefferson batholith & 18.123 & 15.557 & 37.142 \\
\hline NH/Pcy1-81 & Trondhjemite of Jefferson batholith & 18.497 & 15.553 & 38.429 \\
\hline NH/Mo1-84 & Landaff & 18.752 & 15.581 & 38.813 \\
\hline VT/G1-87 & Lost Nation & 17.729 & 15.504 & 37.207 \\
\hline NH/Wh1-79 & Lost Nation & 17.933 & 15.533 & 37.635 \\
\hline M-380-81 & Tunnel Brook & 18.328 & 15.568 & 38.387 \\
\hline NH/MC1-85 & Fairlee & 18.341 & 15.625 & 38.186 \\
\hline $\mathrm{NH} / \mathrm{M} \ln 1-85$ & Umbagog & 18.307 & 15.591 & 38.104 \\
\hline M-270-83 & French Pond & 18.267 & 15.59 & 38.075 \\
\hline OL-126-2 & Sugar Hill & 18.476 & 15.567 & 38.156 \\
\hline OL-133 & Owls Head & 18.386 & 15.569 & 38.156 \\
\hline $\mathrm{Me} / \mathrm{O} 1-81$ & Adamstown & 18.182 & 15.58 & 37.937 \\
\hline NH/L 2-79 & Highlandcroft & 18.154 & 15.568 & 37.868 \\
\hline M-268-83 & Bethlehem Granodiorite & 18.419 & 15.665 & 38.504 \\
\hline M-271-83 & Kinsman Granodiorite & 18.374 & 15.678 & 38.333 \\
\hline
\end{tabular}

${ }^{\mathrm{a}}$ Corrected for mass fractionation of $0.14 \%$ /atomic mass unit.

Ammonoosuc felsic tuff, now poorly stratified pyritic quartz-sericite schist containing sparse chalcopyrite (Moench et al., 1999, Map D). The altered zone is widespread and extends stratigraphically downward into turbidites of the underlying Dead River Formation.

The Ammonoosuc of the Littleton area also is intruded at various stratigraphic levels by many small, $1-10 \mathrm{~m}$ bodies of fine-grained to dense, light-gray, commonly quartz-phyric trondhjemite, probably akin to most of the trondhjemites described by Leo (1985, 1991, pp. 91, 92). Several of the bodies were mapped along the limbs of the Lisbon syncline (Fig. 4C, LS), just below the Ammonoosuc-Partridge contact. This horizon is also characterized in the same area by chemically deposited metachert and silicate iron-formation. As inferred by Moench et al. (1999), the trondhjemites might have been heat sources that drove hydrothermal systems that produced sea-floor chemical sedimentation and possible metallic mineralization.

\subsubsection{Origin of Ammonoosuc sequence}

On the basis of major-oxide and $\mathrm{Ti}-\mathrm{Zr}-\mathrm{Y}-\mathrm{Sr}$ compositions, Aleinikoff (1977) showed that basaltic amphibolite of the Ammonoosuc of western New Hampshire have compositions that are comparable to MORB and island arc tholeiites. Fitz $(1999,2002)$ concluded that the older metadiabase dikes of the Chickwolnepy intrusions (Milan area; Fig. 4B) are arc tholeiites in which water affected magma genesis. According to him, the early dikes were emplaced at shallow depth and likely reached the surface as lavas of the basaltic lower member of the Ammonoosuc Volcanics. He inferred a supra-subduction arc setting accompanied by orogen-parallel extension. On the basis of the abruptness of the Dead River-Ammonoosuc contact and the near absence of volcanics in the Dead River Formation, Fitz inferred that the Chickwolnepy intrusions and the lower Ammonoosuc represent the initial eruptions of an incipient arc. The abruptness of the contact is seen in the Oquossoc and Littleton areas as well (Fig. 4A and C). Fitz's data for the older dikes and the basalts do not distinguish the exact setting (arc vs. fore- or back-arc). Although the younger Chickwolnepy dikes have some minor element signatures of boninites, suggesting a forearc setting, the major oxide compositions are not boninite-like. He suggested that repeated intrusions of the Chickwolnepy mafic magmas partially melted basalt to produce tronhjemite and tonalite of the Chickwolnepy, and may also have melted country rocks to produce granitic magma that now forms the Cambridge Black pluton. The tonalite and trondhjemite might also have formed by fractional crystallization of the gabbroic magma.

Leo (1991) sampled the Ammonoosuc Volcanics extensively from Berlin, NH (Fig. 4B, several km south of Milan) to Littleton and farther south along the Bronson Hill belt. Although Leo worked before the Ammonoosuc and Quimby were adequately sorted, of 25 mafic and intermediate samples that he collected (his Table 2), only 2 (nos. 74 and 75) came from our Quimby and at least 18 came from our certain Ammonoosuc; of his 14 felsic samples, 12 are from our certain Ammonoosuc. Overall, Leo's data for the Ammonoosuc show a conspicuous bimodality (Leo, 1991, Fig. 39); his mafic rocks are primitive arc tholeiites, in accord with Fitz's data, and his felsic rocks are calc-alkaline. Leo (1985) also inferred a supra-subduction origin for trondhjemites of the Bronson Hill belt.

Schumacher's (1988) major oxide data for amphibolites of basaltic composition in his lower member of the 
Ammonoosuc Volcanics of the Massachusetts-SW New Hampshire area, probably related to our Ammonoosuc sequence, are comparable to Fitz's (1999) data for mafic Ammonoosuc volcanics near the Chickwolnepy intrusions (Schumacher, 1988, Table 1; Fitz, 1999, Table E.1, lava). All have low $\mathrm{K}$ contents $\left(\sim 0.4 \pm 0.25 \% \mathrm{~K}_{2} \mathrm{O}\right)$, and moderate Ti contents $\left(1.0 \pm 0.6 \% \mathrm{TiO}_{2}\right)$. Minor element and major oxide data for both mafic sequences indicate an island arc association, as do Schumacher's data for felsic rocks of the lower Ammonoosuc and Fitz's data for Chickwolnepy tonalites and trondhjemites (Schumacher, 1988; Fitz, 1999, 2002).

Overall, our Middle Ordovician Ammonoosuc sequence, the Shelburne Falls arc of Karabinos et al. (1998), and the 460-462 Ma rhyolite and subvolcanic granite of the Ascot Complex (David et al., 1993; Tremblay et al., 2000) can be viewed as a complex but generally west-facing arc to fore-arc succession above an east-dipping subduction zone. This interpretation assumes first that the Dead River-Aziscohos flysch sequence is correctly correlated to the Moretown Formation of Vermont, and to the lower part of the Magog Group of Quebec, both inferred fore-arc basin deposits of Laurentian provenance (Karabinos and Gromet, 1993; Cousineau, 1994); and that the boninitic amphibolites of the Hawley Formation of Massachusettes (Kim and Jacobi, 1996) are indicative of fore-arc magmatism. Although the west-east width of this belt seems excessive for this interpretation, the width of the belt may have been considerably narrower before the onset of major Silurian orogen-normal extension, here inferred to have produced the Connecticut Valley-Gaspé trough, as described in a later section (see also Moench, 1996b).

\subsection{Upper Ordovician and Lower Silurian Quimby sequence}

The Quimby sequence contains metasedimentary and metavolcanic rocks assigned to the Quimby Formation and intrusive rocks assigned to the Highlandcroft and Oliverian Plutonic Suites.

\subsubsection{Quimby Formation}

This formation was named by Moench (1969) for exposures of weakly metamorphosed graywacke and dark-gray to black slate near Quimby Brook in the Rangeley 15-min quadrangle (Fig. 4A). The type area includes several exposures north and east of Rangeley Lake; the formation is widely exposed around the lake.

3.5.1.1. Distribution and lithologic description. The lower member of the Quimby Formation north of Rangeley Lake is composed of thickly bedded, lithic metagraywacke that gradationally overlies a "flaggy" unit of thinly interbedded black slate and metagraywacke in the uppermost part of the Partridge Formation. Metagraywacke beds of the member are $15-150 \mathrm{~cm}$ thick and are poorly graded; some are separated by thin interbeds of black slate. The lower parts of some of the thickest beds are conglomeratic, containing rounded pebbles of vein quartz and rodded pebbles and small cobbles of various sedimentary and volcanic rocks. The member is about $300 \mathrm{~m}$ thick. It grades laterally to the volcanic member, having a maximum thickness of about $200 \mathrm{~m}$. Weakly metamorphosed volcanics of the member are white-weathering felsic tuff, massive to flow-laminated sodarhyolite flows, and rhyolitic probable domes.

The graywacke and volcanic members are conformably overlain by the graywacke and shale member, about $700 \mathrm{~m}$ thick. It is composed of rusty-weathering dark-gray to black, weakly graphitic slate interbedded with subequal amounts of typically well graded metagraywacke, and an extensive layer of thick-bedded, conglomeratic metagraywacke. Black pyrrhotitic slate and metagraywacke of uppermost Quimby is conformably overlain by nonsulfidic, slightly calcareous, palegray to purply gray laminated metasiltstone of the Lower Silurian Greenvale Cove Formation. The Greenvale Cove is the basal formation of the Silurian successor basin sequence (Fig. 3, Sb).

The upper graywacke and shale member comprises the main body of the Quimby in the Milan area (Fig. 4B), where it is also conformably overlain by the Greenvale Cove Formation. The Quimby-Greenvale Cove of the Milan area define a tight northwest-trending syncline that is flanked by underlying rocks of the Ammonoosuc Volcanics.

Near Umbagog Lake, abundantly pyritic quartzmuscovite schist of the Ammonoosuc is sharply overlain by a thin layer of calc-silicate rock (Fig. 4B, SOqu), first recognized by Milton (1961), and here named the calcsilicate member at Upton. The member is here considered the basal unit of the Quimby Formation. It is about 5-10 $\mathrm{m}$ thick and extends about $9 \mathrm{~km}$ along the Ammonoosuc-Quimby contact. The most characteristic rock of the member is thinly laminated calc-silicate rock and white marble, strongly contact metamorphosed (locally with wollastonite) by the Umbagog pluton (Fig. $4 \mathrm{~B}, \mathrm{Dn} 2)$. White to green quartzite containing calc-silicate minerals is commonly conspicuous, and a small body of polymictic boulder conglomerate was found in one outcrop immediately below quartzite and calc-silicate rock.

The sharp lower contact of the member is interpreted to mark a possibly major, but local, unconformity. According to our interpretation, the Partridge Formation, which is well exposed above the Ammonoosuc in the Quimby and Littleton areas (Fig. 4A and B) and along the Rice Mountain syncline of the Milan area (Fig. 4B, RMS), was removed by erosion before 
deposition of the Quimby Formation southeast of the RMS in the Milan area.

In the Littleton area, the Quimby Formation is mainly contained within the Lisbon and Tinkerville synclines (Fig. 4C; LS, TS). A small synclinal body also is exposed about $5 \mathrm{~km}$ northeast of Lisbon, where the volcanic member is interpreted to be unconformbly truncated at the base of the Lower Silurian Clough Quartzite, although the actual contact is not exposed.

A narrow synclinal belt of interbedded black sulfidic schist and metagraywacke of probable uppermost Quimby occurs along the troughline of the Lisbon syncline (Fig. 4C, SOqs). This belt is flanked by rocks of the bimodal volcanic member, which is about $1 \mathrm{~km}$ thick.

In the Lisbon syncline, the volcanic member is bimodal but predominantly felsic in composition. The felsic rock is largely white-weathering, plagioclase-rich, biotite-quartz-plagioclase granofels, possibly strongly keratophyric. Spectacular exposures of the granofels along the Wild Ammonoosuc River at Swiftwater village (Fig. 4C) show primary depositional details including, among others, a very thickly bedded tuff-matrix volcanic conglomerate that grades to homogeneous ash tuff; massive pumice lapilli tuff; and an inversely graded bed of pumice lapilli tuff, with a sharp lower contact that channels underlying tuff beds. Variations of these types occur elsewhere in the Lisbon and Tinkerville synclines, including thin to thick graded beds of massive tuff, and conglomeratic tuff and pyroclastic flow deposits.

Mafic types of the Quimby are composed of black amphibolite in the Lisbon syncline, and greenish-black chlorite-rich calcitic greenstone in the Tinkerville syncline, which contains subequal amounts of mafic and felsic rocks. The basalts of both synclines are mainly pyroclastic, as best seen on the south bank of the Wild Ammonoosuc River about $1.6 \mathrm{~km}$ downstream from Swiftwater. Exposed here are several graded beds of black amphibolite, some with basal load casts; finegrained amphibolite of the beds supports equant plagioclase crystals (as large as $1 \mathrm{~cm}$ across) that are most abundant in the lower part of each bed. Leo (1991, Table 2, nos. 74 and 75) collected two samples from this outcrop. Both are clearly basaltic, with $\sim 50 \% \mathrm{SiO}_{2}$ (volatile free) and exceptionally low total alkali $(2.01 \%$ and $1.10 \%)$ and $\mathrm{TiO}_{2}(0.79 \%$ and $0.43 \%)$ contents, compared to most other mafic rocks of his sample suite. His Quimby samples, however, came from clearly resedimented basalt tuff, not lavas, and may have been differentiated during sedimentation. Plagioclase-phenocrystic basaltic metatuff is also abundant in the Quimby of the Tinkerville syncline, which also contains a few meter-thick beds of massive and pillowed basaltic greenstone.

3.5.1.2. Nature of lower contacts. As described above, the lower contact of the Quimby Formation is con- formable in the Oquossoc area, but probably is a major unconformity in the Milan area. Contact relationships at the base of the Quimby Formation in the Littleton area indicate that the formation crosses a southeastfacing tectonic hinge from conformity on the southeast limb of the Lisbon syncline, to disconformity on the northwest limb, and to major unconformity on both limbs of at least the northern portion of the Tinkerville syncline. This syncline is interpreted as a down-faulted remnant of the Lisbon syncline, on opposite sides of the Ammonoosuc fault.

A large, stream-washed pavement outcrop that beautifully exposed the Partridge-Quimby contact (until it was recently covered by grassed-over stream sand) on the southeast limb of the Lisbon syncline, occurs on the north bank of the Wild Ammonoosuc River $1 \mathrm{~km}$ upstream from Swiftwater village (Fig. 4C). There, as mapped by Moench in 1983, black schist of the Partridge Formation occurs in the core of an isoclinal anticline whose limbs expose graded bedded white to pale orange felsic metatuff of the Quimby. Graded beds in the Partridge and Quimby of the northwest limb of the anticline indicate that the Quimby gradationally overlies the Partridge; the gradation, by interbedding, occurs within the space of about $1 \mathrm{~m}$. Although the obscuring sand might be removed without difficulty, the present landowners prohibit activity of any sort on their outcrop.

At Bath, NH, on the northwest limb of the Lisbon syncline, the same contact is a knife-sharp disconformity or an unconformity. Here the basal Quimby is a $10-\mathrm{m}$ thick bed of massive, coarse-grained, biotite-muscovitequartz-plagioclase granofels (felsic crystal metatuff) that supports scattered rip-up slivers and chips of dark-gray metasiltstone and coaly-black slate derived from the underlying Partridge Formation. The bed is interpreted as a high-energy, geologically instantaneous clastic flow deposit that eroded the Partridge sediments, and perhaps some Quimby volcanics that might have overlain the Partridge.

Clear evidence of deep erosion below the northernmost outcrops of the Quimby Formation is exposed around the south-plunging synclinal "bend" of the Tinkerville syncline, about 4-6 km southwest of Moore Dam (Fig. 4C) at the west end of Moore Reservoir. Here, the lower contact of the Quimby cuts across the Partridge Formation and Ammonoosuc Volcanics, and channels into the Dead River Formation. The basal 30 $\mathrm{m}$ of the Quimby of this area contain a variety of metamorphosed debris-flow conglomerates. Examples on the southeast limb of the Tinkerville syncline include: (1) a 4-m-thick bed at the base of the Quimby, composed of gritty volcanic mudstone that supports an unsorted mixture of equant to slightly flattened felsite pebbles, and swirls, clots, and blocks of black slate of various sizes derived from the immediately underlying Partridge 
Formation; (2) a nearby 8-m-thick debris-flow bed, several meters above the basal Quimby contact, composed of similar volcanic mudstone that supports an angular slab of "pinstriped" quartzite, possibly derived from the Dead River Formation, and rounded to subangular pebbles to small boulders of ash-tuff, felsite, dark greenish-gray, quartz-porphyritic tonalite, and one rounded cobble of an altered holocrystalline granitoid. On the northwest limb of the syncline is a 60-m-thick sequence that contains: (1) massive felsic metatuff with sparse outsized stretched rounded cobbles of white, finegrained, equigranular trondhjemite, and a rounded boulder of Highlandcroft-like, pinkish-gray, mediumgrained, seriate-porphyritic granite; (2) a more abundantly conglomeratic bed of gritty mudstone that supports boulders and cobbles of dark greenish-gray, richly quartz-porphyritic tonalite(?), and less abundant cobbles and pebbles of dark-gray probable andesite tuff, and quartzite.

3.5.1.3. Age. The Quimby Formation of the Littleton area is dated only by a single $\mathrm{U}-\mathrm{Pb}$ zircon age of $443 \pm 4$ Ma (Table 1), obtained from the thick metatuff bed that is exposed immediately above the sharp PartridgeQuimby contact. The locality is just below the power dam at Bath, NH Although the dated bed directly overlies the Partridge Formation, an unknown quantity of Quimby tuff was probably eroded before deposition of the dated bed. Because $443 \mathrm{Ma}$ is the approximate age of the Ordovician-Silurian boundary (Tucker and McKerrow, 1995), a Late Ordovician to Early Silurian in age can be assigned to the formation. In the Oquossoc area, the age of the Quimby Formation is constrained only by the $C$. bicornis zone graptolites found in the Partridge Formation several hundred meters below the Quimby (Fig. 4A, northern site in Partridge), and by upper Llandoverian shelly fossils that occur several hundred meters above the Quimby, in a shoal facies of the upper member of the Silurian Rangeley Formation (Fig. 4A, three sites east of SE end of Kennebago Lake). The fossil data are given in Moench et al. (1995).

\subsubsection{Correlations. The Quimby Formation is broadly} correlated to the south with the upper member of the Ammonoosuc Volcanics and the overlying Partridge Formation as mapped and dated $(453,449 \mathrm{Ma})$ in the Bronson Hill belt of Massachusetts and southern New Hampshire (Schumacher, 1988; Tucker and Robinson, 1990). To the northwest, it might be equivalent to the youngest of two dated rhyolites $(441+6 /-8 \mathrm{Ma})$ of the Ascot Complex in Quebec (David et al., 1993).

To the northeast, the Quimby is correlated with the Lobster Mountain Volcanics of the Moosehead Lake area, at the northeast end of the Lobster Mountain anticlinorium (Fig. 1, left side, LMA). The Lobster Mountain, composed of rhyolitic felsite and tuff, ag- glomerate, and within-plate basaltic greenstone (Boucot, 1969, p. 56; Winchester and van Staal, 1994), contains a shelly fauna of late Cincinnati (Ashgill) age (Neuman, 1973) that approximately accords with our interpretation of the age of the Quimby Formation. Three small bodies of probable Lobster Mountain Volcanics occur near the east side of the Chain Lakes massif (Fig. 2; $\mathrm{SOv}$ ); two in contact with the Attean pluton (index SO1), and one in contact with the Hurricane Mountain Formation. Rocks of these bodies include weakly metamorphosed quartz porphyry, tuffaceous siltstone, sandstone, and feldspathic tuff, andesite, volcanic breccia and volcanic conglomerate. These rocks might be eruptive facies of the $443 \pm 4$ Ma Attean pluton.

It is tempting to correlate the Quimby with all of the within-plate basaltic sequences of northern Maine (Winchester and van Staal, 1994), including the undated basalts at Stacyville and Mount Chase in the Lunksoos anticlinorium (Fig. 1, LSA), and the fossiliferous Bluffer Pond and Winterville Formations of the MunsungunWinterville anticlinorium. At least the Bluffer Pond and Winterville are mainly early Mohawkian in age - too young for the Ammonoosuc correlatives and probably too old for Quimby correlatives.

\subsubsection{Highlandcroft Plutonic Suite}

Billings (1937) used the name Highlandcroft magma series, now termed the Highlandcroft Plutonic Suite (Moench et al., 1995), to designate massive to foliated granitic to locally intermediate and mafic plutons that intrude stratified Ordovician rocks northwest of the axial trace of the Bronson Hill anticline in northern New Hampshire. The suite has been studied by Pogorzelski (1983) and its general characteristics are summarized by Leo (1991, p. 52), who listed four analyses from the Lost Nation pluton (his Table 2, nos. 55-60). Lyons et al. (1986) showed that most of these bodies are Late Ordovician in age, although at least two (Attean and Lost Nation) are now known to have crystallized at or slightly later than the time of the Ordovician-Silurian boundary (Tucker and McKerrow, 1995, 443 Ma). For this reason a Late Ordovician to Early Silurian age is assigned to the suite.

All identified Highlandcroft plutons occur within the area of Fig. 2. Likely correlatives occur, however, in southwestern Connecticut between the Triassic basin and Cameron's line. There, Sevigny and Hanson (1995) reported Late Ordovician and Early Silurian $\mathrm{U}-\mathrm{Pb}$ crystallization ages of $454-436 \mathrm{Ma}$ for the intrusive Newtown Gneiss and Brookfield Plutonic series, and inheritance ages of both $(\sim 1121-1194 \mathrm{Ma})$ that are consistent with derivation from Grenvillian basement. The inheritance data favors correlation to the Highlandcroft Suite, rather than Oliverian plutons, which show virtually no evidence of Precambrian inheritance. 
The named Highlandcroft bodies are (Fig. 2; index numbers from north to south): Attean (SO1), Catheart Mountain (SO2), Sally Mountain (SO3), Skinner (SO4), Adamstown (SO5), Lost Nation (SO6), Whitefield (SO7), and Highlandcroft (SO8). U-Pb ages of these bodies range from $452 \pm 4 \mathrm{Ma}$ for the Adamstown (Lyons et al., 1986) to $442 \pm 4 \mathrm{Ma}$ for the northern portion of the Lost Nation (Table 1), and $441 \pm 1 \mathrm{Ma}$ for a probable offshoot of the Lost Nation to the north of the main body (Rankin and Tucker, 1999; not shown in Fig. 2). Lyons et al. (1986, Table 2) reported K-Ar and $\mathrm{Rb}-\mathrm{Sr}$ muscovite ages of $441 \pm 8$ and $447 \pm 10 \mathrm{Ma}$ for muscovite-molybdenite greisen in the Catheart Mountain pluton, which intrudes the Attean, in close agreement with their U-Pb zircon age of $443 \pm 4$ Ma for the adjacent Attean pluton.

Highlandcroft bodies are variably foliated, and are variably retrograded to the ambient greenschist metamorphic facies of the country rocks. The plutons intrude only Middle Ordovician and older stratified rocks. Most of the bodies are composed of two-feldspar granite and granodiorite, with biotite and/or hornblende. They tend to be pink, medium to coarse grained, and variably massive to seriate-porphyritic or strongly feldsparporphyritic. The Sally Mountain and Catheart plutons are hypabyssal, and the Catheart hosts an important (but subeconomic) copper-molybdenum porphyry deposit (Ayuso, 1989; Moench et al., 1999). The Lost Nation pluton is divided into a northern body of pink biotite granite (see Leo, 1991, analysis no. 56), and a southern body of gray granodiorite to diorite or gabbro (Leo analyses nos. 55, 59 and 60); ages of both are dated within error at 443 and $442 \mathrm{Ma}$ (Table 1). Contact metamorphic aureoles mapped at the borders of the Lost Nation and type-Highlandcroft plutons are narrow $(100-300 \mathrm{~m})$ and strongly retrograded; both locally contain abundant granitic offshoots and borders of both plutons are chilled. These plutons are exposed just west of the west-dipping Ammonoosuc normal fault (AF); although the Whitefield pluton, exposed immediately east of the fault is undated, the Lost Nation and typeHighlandcroft might be down-dropped "decapitated" remnants of the Whitefield pluton east of the fault. According to Billings (1937), however, the Whitefield pluton is intruded by the Oliverian Scrag granite of Billings (1937), which is dated at $456 \pm 3$ Ma (Table 1) significantly older than available data from the Lost Nation and Highlandcroft plutons.

\subsubsection{Oliverian Plutonic Suite}

Billings (1937, p. 501) and Billings (1956, p. 48) used the name Oliverian magma series, now termed the Oliverian Plutonic Suite, to designate strongly foliated intrusive granitic rocks exposed in the cores of several gneiss domes that define Bronson Hill anticline, or anticlinorium (Figs. 1 and 2, BHA). The Oliverian plutons shown in Fig. 2 are the composite Jefferson batholith (SO9), and the Sugar Hill (SO10), Landaff (SO11), Moody Ledge (SO12), Tunnel Brook (SO13), and Owls Head (SO14) plutons. Because rocks of the suite have yielded $\mathrm{U}-\mathrm{Pb}$ zircon ages of 456-435 $\mathrm{Ma}$ (Table 1) and an $\mathrm{Rb}-\mathrm{Sr}$ whole-rock age of $441 \pm 5 \mathrm{Ma}$ (Foland and Loiselle, 1981), the suite is Late Ordovician and Early Silurian in age. Leo (1991, Table 2) has described the principal Oliverian domes and has published many chemical analyses of rocks from the suite.

3.5.3.1. Description. The most abundant Oliverian rock type in the area is pink biotite granite, locally containing hypabyssal rhyolite porphyry noted by Leo (1991, Table 1) in the Sugar Hill and Moody Ledge plutons. The Landaff pluton contains fine-grained leucocratic hastingsite-bearing granodiorite as well as fine-grained granite, and the Jefferson batholith is a composite body that contains biotite trondhjemite that grades to granodiorite and quartz diorite, biotite granite, hornblendebiotite granite, and hornblende-biotite quartz syenite to syenite. Interestingly, the mildly alkalic rocks, described and dated by Foland and Loiselle (1981), occur where the Jefferson batholith is crossed by the north-trending belt of Jurassic alkalic plutons of the White Mountain Plutonic-Volcanic Suite.

The Tunnel Brook pluton was previously interpreted as the eastern slice of the Moody Ledge pluton (Moench et al., 1995, 1999), on the basis of field relationships suggesting that it was displaced from the Moody Ledge by the intervening Devonian Mount Clough pluton (Fig. 4C; Dnb). Both the Moody Ledge and Tunnel Brook plutons are composed of pink, fine-grained biotite granite, and both are deformed along their eastern margins by high-temperature mylonite showing evidence of partial melting. Although the anomalously young age of the Tunnel Brook pluton $(435 \pm 3 \mathrm{Ma}$, Table 1) is probably primary, it might date mylonitization under partial melting conditions (see Appendix A, I).

3.5.3.2. Contacts and doming history. The nature of the contact between the gneissic cores and the stratified mantles of the domes has been debated ever since Naylor (1969) proposed that the strongly gneissic outer portion of the core of the Mascoma dome of westcentral New Hampshire is felsic to intermediate metatuff that lies stratigraphically beneath predominantly mafic rocks of the Ammonoosuc Volcanics. According to his model, during or shortly after their eruption the stratified core-rocks were intruded by granitic magma, now represented by relatively massive granite in the core of the dome. However, the isotopic dating of this paper, and field observations by Billings (1937), Leo (1991), and by Moench at the borders of the Moody Ledge, Landaff, and Whitefield plutons indicate that Oliverian plutons north of the 44th parallel intrude the distinctly 
older Ammonoosuc Volcanics and Dead River Formation (Fig. 4B and C).

Other researchers have argued, on the basis of geochemical contrasts between tholeiitic volcanics and calc-alkaline Oliverian dome gneisses, for major faults between these rock assemblages (Peter Robinson in Tucker and Robinson, 1990, p. 1417; Hollocher, 1993). Lyons et al. (1996, p. 881) noted that gravity models for Oliverian domes cored by the Moody Ledge and Owls Head plutons of the Littleton area (Fig. 4C) and the Baker Pond and Smarts Mountain plutons father south "are consistent with the interpretation that they may be intrusive sheets or may be floored by thrusts". The mushroom shape of the Mascoma dome, however, with its central steep-walled stalk (Lyons et al., 1996, Fig. 8, E-E'), "is not supportive of the thrust hypothesis for the base of this dome".

In summary, the field observations given above and the gravity models of Lyons et al. (1996) indicate that the upper and lower contacts of the Oliverian plutons are intrusive. It is not reasonable, therefore, to invoke major thrusting on the sole basis of petrochemical contrasts. Interstratified tholeiitic basalts and calcalkaline silicic volcanic rocks occur, for example, in the Coastal Volcanic arc (Fig. 1, CVA) and elsewhere (Gates and Moench, 1981, and references).

The youngest unit affected by doming is the Lower Devonian Littleton Formation, and it is accepted that doming is a late Acadian feature (Thompson et al., 1968). Each dome is defined by gneissic fabric, most strongly developed within the outer part of its granitic core, that approximately conforms to the attitudes of the mantling formations. This relationship only broadly applies to the northeast end of the Jefferson dome, however, where dome-stage foliation arcuately crosses the granitic Cambridge Black pluton and the Chickwolnepy intrusions.

\subsubsection{Extent, correlations, and relationship to base-} ment. The Oliverian Plutonic Suite forms the cores of the Oliverian domes along the Bronson Hill anticlinorium from western Maine south to central Connecticut, east of the Triassic basin (Leo, 1985, Fig. 1). Although the Oliverian gneisses of the southern New HampshireMassachusetts area were long interpreted as basement below the Ammonoosuc mantles of the domes, Tucker and Robinson (1990) showed that the gneisses are intrusive, with Late Ordovician ages that overlap ages obtained from the upper Ammonoosuc and overlying Partridge of that area. As described by Hollocher et al. (2002), the Oliverian gneisses of that area (Monson of Monson dome, and Fourmile of Pelham dome) are predominantly calc-alkaline tonalite to granodiorite in composition, but locally include calc-alkaline gabbro. He noted that compositions change northward to predominant granites, as described above, suggesting that the northern part of the arc was based on continental crust. As shown by Lyons et al. (1997), this change occurs most conspicuously just south of Lebanon, $\mathrm{NH}$, but it is not abrupt and it does not occur without exceptions. For example, the granite cores of the Mascoma, Lebanon, and Baker Pond domes north of Lebanon are bordered by granodiorite to tonalite, and the granite core of the Keene dome, southwestern $\mathrm{NH}$, occurs within a much larger area of undivided granite to tonalite. Moreover, the northeast tip of the Jefferson batholith contains a sizeable area that is underlain by granodiorite to quartz diorite. However, geophysical data (Fig. 1) do show changes in the apparent position of the eastern margin of Grenville crust that might correlate to the imperfect compositional changes cited above.

\subsubsection{Origin of the Quimby sequence}

On the basis of stratigraphic and geochemical studies of rocks mapped as the Ammonoosuc Volcanics and Partridge Formation in Massachusetts and southern New Hampshire, Schumacher (1988) and Hollocher (1993) concluded that both units were erupted along a supra-subduction island arc. As already described, we correlate the lower Ammonoosuc of that area with our Middle Ordovician Ammonoosuc sequence, and the upper Ammonoosuc and Partridge of that area with the Upper Ordovician to Lower Silurian Quimby sequence. At least minor geochemical differences might be expected, and Schumacher (1988, pp. 650-655) found possibly significant differences between felsic volcanics of the lower and upper members. According to his data, felsic rocks of his upper member have higher $\mathrm{K}$, Ba, and $\mathrm{Rb}$ contents than those of his lower member, and some rocks of his lower member (type-B) have extremely low contents of these elements.

Schumacher (1988, p. 655) concluded that the lower and upper member felsic volcanics were probably not generated by partial melting of the same material. We ask: Might these differences express the absence and presence, respectively, of sialic basement? If "yes", one might expect to see evidence of ensialic magmatism in Hollocher's (1993) data for the overlying Partridge Formation. Simple comparison of tabulated data of Hollocher (1993, Table 1) and Schumacher (1988, Tables 2 and 4, lower and upper members) indicate that felsic gneisses of Hollocher's Partridge have high K, Ba, and $\mathrm{Rb}$ contents that are comparable to those of Schumacher's upper Ammonoosuc. Although these data are consistent with a tentative "yes", only sparse isotopic evidence of inheritance from ancient basement has been recognized so far along the Bronson Hill belt: A xenocrystic (or possibly detrital) zircon grain from the Jim Pond Formation (Moench et al., 2000); a U-Pb zircon upper intercept age of $\sim 1500$ Ma from the Lost Nation pluton (Lyons et al., 1986); upper intercept ages of 
$\sim 1056 \mathrm{Ma}$ (Newtown Gneiss), $\sim 1150$ and $\sim 1194 \mathrm{Ma}$ Brookfield plutonic series in southwestern Connecticut (Sevigny and Hanson, 1995). These data are consistent with the view that the Grenville margin was close to its present position (Fig. 1) by Late Ordovician time.

A magmatic arc setting for plutonic rocks that we correlate to the Quimby sequence is widely affirmed (e.g., Hollocher et al., 2002; Leo, 1991; Sevigny and Hanson, 1995). On the basis of inheritance patterns, Sevigny and Hanson concluded that the southwestern Connecticut plutons were generated and emplaced along the Grenville margin. We suspect that the same is true of the Highlandcroft plutons of the Bronson Hill belt. The Oliverian plutons, lacking evidence of inheritance, may have been generated just off the margin.

The Quimby volcanics of the Littleton to Oquossoc area have not been studied petrochemically, but Winchester and van Staal (1994) assigned weakly metamorphosed basalts of the Upper Ordovician (upper Cincinattian) Lobster Mountain Volcanics (here correlated to the Quimby) in Maine to their within-plate group of tholeiites. According to them (p. 655), the Lobster Mountain basalts (and other basaltic units in Maine that we do not specifically correlate to the Quimby) show no indication of any contribution from a suducting slab; they accordingly ruled out generation of these rocks in an active arc setting.

With the possible exception of the Lobster Mountain within-plate basalts in Maine, we consider the Quimbysequence to have been generated above a Late Ordovician to Early Silurian subduction zone that dipped northwest, following an early Late Ordovician magmatic hiatus and reversal of subduction polarity, much as proposed by Karabinos et al. (1998, Fig. 5). The small Silurian(?) Bald Mountain terrane of northern Maine (Slack et al., 1999) might relate to the NW-dipping subduction zone. This hypothesis is discussed more thoroughly in the final section of this paper.

\subsection{Summary of stratigraphic correlations along the Bronson Hill belt}

As shown diagrammatically in Fig. 5, rocks of the Middle Ordovician (Whiterockian) Ammonoosuc Volcanics of the Littleton, Milan, and Oquossoc areas are tentatively correlated to rocks mapped as the lower member of the Ammonoosuc of Massachusetts and southwestern New Hampshire, and to the probably Middle Ordovician Kennebec Formation at Moosehead Lake. We recognize no Ammonoosuc correlatives farther northeast in Maine, although fossil data indicate that post-Ammonoosuc portions of the sedimentary Mohawkian ( Caradocian) Partridge Formation are at least partly coeval with volcanics of the Bluffer Pond and Winterville Formations of the Munsungnun-Winterville anticlinorium (Fig. 1, MWA) north of the
Moosehead Lake area, and with the Wassataquiok Chert of the Lunksoos anticlinorium (LSA) to the east, as shown by Neuman (1984). These Mohawkian deposits may be coeval with the metamorphosed cherts that separate the lower and upper members of the Ammonoosuc, as mapped in Massachusetts and southern New Hampshire (Schumacher, 1988).

Pre-Ammonoosuc flysch of the lower Middle and Lower Ordovician Dead River Formation is well exposed near Littleton and farther northeast in Maine, but is not recognized south of the Littleton area. Below the Dead River of the Oquossoc-Chain Lakes area is the Lower Ordovician ophiolitic melange sequence consisting of the Hurricane Mountain and Jim Pond Formations and the stratiform, mafic-ultramafic Boil Mountain Complex. The Jim Pond and Hurricane Mountain are mapped at Moosehead Lake and elsewhere in northwestern Maine (Boone and Boudette, 1989), but no farther south than the Oquossoc-Chain Lakes area. Ages for the entire Ammonoosuc to Jim Pond sequence are comparable, however, to those of the Shelburne Falls arc and fore-arc sequences of central Vermont to western Massachusetts, and we concur with Karabinos et al. (1998) that these sequences belong to the same magmatic arc, despite their occurrence on opposite sides of the Connecticut Valley-Gaspé trough. Parts of the Ascot Complex, Quebec, that have yielded ages of 460 and $462 \mathrm{Ma}$, and the Frontiére and Etchemin Formations of lower Magog may belong to the same volcanosedimentary assemblage.

As shown on column A, the Boil Mountain Complex is separated from the underlying Neoproterozoic(?) Chain Lakes massif by the Boil Mountain suture (BML). According to the seismic profile of Stewart et al. (1993), the massif is a flat-lying tabular body about $4 \mathrm{~km}$ thick that is directly underlain by Grenville basement. Although Stewart and others suggested that Chain Lakes rocks were deposited directly on the Grenville, we speculate that the contact is a flat segment of the Baie Verte-Brompton suture (Fig. 5, BBL). This interpretation is based on the fact that the surface exposures of Chain Lakes rocks and their correlatives lie above the BBL in Quebec, and below the BML in Maine. The Chain Lakes, composed mainly of sedimentary, granofels-matrix diamictite, may have formed during early Iapetan rifting (Cousineau, 1991). It is probably no older than $\sim 571 \mathrm{Ma}$ (Dunning and Cousineau, 1990), or $>40$ m.y. younger than the lithologically different Neoproterozoic Dry Hill and associated gneisses, dated at $613 \pm 3 \mathrm{Ma}$, of the Pelham dome of Massachusetts (Tucker and Robinson, 1990).

Whether or not the Neoproterozoic Dry Hill Gneiss and related gneisses in the core of the Pelham dome, Massachusetts, were emplaced by an Alleghanian underthrust of enormous displacement depends on the validity of evidence that the DHG was metamorphosed 
only in Late Paleozoic time, whereas the mantling Ordovician to Early Silurian rocks underwent high rank Acadian regional metamorphism (Wintsch et al., 1992, 1993; Getty and Gromet, 1992a,b; Robinson et al., 1998, pp. 126, 127). If evidence of Acadian metamorphism is revealed in the DHG, it would be reasonable to infer that no major fault exists at the Pelham core-mantle boundary. This would imply that the mantling rocks were deposited directly on the DHG.

Metamorphosed sedimentary and volcanic rocks of the Quimby Formation are correlated to the upper member of the Ammonoosuc and the overlying Partridge Formation of the MA-NH area (Fig. 5, column D), and to the Cincinnatian Lobster Mountain Volcanics of the Moosehead Lake area.

Deposition of the Quimby probably followed a magmatic hiatus represented by the post-Ammonoosuc portions of the Mohawkian Partridge Formation, with its common basal cherts and iron-formation. This hiatus may also be expressed by the cherty horizon that intervenes between the undated lower member (Middle Ordovician?) and the dated upper member (Upper Ordovician) of the Ammonoosuc in MA-NH (Schumacher, 1988), and possibly by widespread Late Ordovician within-plate basaltic outpourings unrelated to subduction in northern Maine (Winchester and van Staal, 1994). Quimby deposition also followed erosion that locally removed some of these post-Ammonoosuc deposits, and locally channelled deeply through the Ammonoosuc.

\section{Proposed delineation of accreted terranes}

The terrane structure shown in Fig. 1 differs markedly from previously published accounts and readers are referred, for example, to Zen (1989), Stewart et al. (1993), and van Staal et al. (1998) for comparison. The account of Stewart et al. (1993) is most pertinent to this paper because the line of the Quebec-Maine transect crosses the area of Figs. 1 and 2. In our definitions we adhere to the principle that an accreted terrane consists of oceanic and/or continental basement and covering deposits and intrusives that were emplaced before or during accretion to another terrane. The two terranes may then become a single composite terrane that acquired an additional load before or during accretion to yet another terrane, or continental margin. Post-collisional magmatic or sedimentary belts may disregard the older terrane structure, and are not appropriately included in the definition of the underlying terrane. For example, whereas the Central Maine composite terrane of Stewart et al. (1993) includes enormously thick Middle Paleozoic successor basin deposits as well as Ordovician and older rocks, all of the Upper Ordovician through Lower Devonian deposits of the same area are expressly excluded from our definitions of terranes $1-3$, because these younger deposits covered all three terranes after their combined accretion to Laurentia.

We start with the Red Indian line (Fig. 1), which is the principle Iapetan suture of Newfoundland (Williams et al., 1988).

\subsection{A search for the Red Indian line in New England}

On the basis of faunal and other geologic contrasts, Williams et al. (1988) divided the Dunnage zone of Newfoundland into two sharply separated subzones termed the Notre Dame subzone on the northwest, and the Exploits subzone on the southeast. Whereas the Notre Dame belt contains a sparse Lower to lower Middle Ordovician North American conodont fauna that evolved on or near Laurentia, the Exploits belt and the Gander zone to the southeast contain an approximately coeval Celtic brachiopod fauna thought to have evolved far to the south, on islands within Iapetus or on Avalon itself in Early Paleozoic time (Neuman, 1984; Harper et al., 1996). The boundary of rock assemblages containing these contrasting faunas passes through Red Indian Lake (Williams et al., 1988, Fig. 1) and is named the Red Indian line (RIL). It is interpreted as the principal Iapetan suture. Although Dubé et al. (1996) showed that the RIL in Newfoundland is a zone of complex deformation that includes major Devonian faulting, the post-Ordovician deformation is likely a result of reactivation of an Ordovician suture.

van Staal (1994, Fig. 1) projected the RIL to the Chaleur Bay area of mainland Canada (Fig. 1), where it is covered by Silurian and younger deposits. van Staal et al. (1998) later correlated the RIL to the Boil Mountain line in western Maine (Fig. 1, BML), which is the most obvious suture zone that is more or less on strike with Chaleur Bay. By suggesting that the Bronson Hill arc was built on basement of Gondwanan affinity, Robinson et al. (1998) implied a similar correlation. The nature of the basement that actually existed during eruptions of the Bronson Hill arc is unknown, however, because strong but inconclusive evidence suggests that the Avalonian basement that now lies below the Ammonoosuc in the Pelham dome (Fig. 1, DHG) was thrust to that position in Late Paleozoic time (Wintsch et al., 1992, 1993; Getty and Gromet, 1992a,b). Alternatively, Skehan (2001, figure) has proposed that the boundary between his Laurentian and Gondwanan terranes (our Red Indian line) lies just east of the Bronson Hill belt in Massachusetts.

We here attempt to trace the RIL through Maine and New Hampshire on the basis of faunal and paleomagnetic (paleopole) data, common lead data, and $\mathrm{U}-\mathrm{Pb}$ zircon inheritance and detrital zircon data. 


\subsubsection{Faunal and paleomagnetic contributions}

Our proposed RIL and terrane delineation (Fig. 1), with two of possibly several alternatives, is modified partly from faunal and paleolatitude data summarized by Mac Niocaill et al. (1997, and references therein). Whereas rocks containing Cambrian to Middle Ordovician brachiopods of North American affinity originated at $\sim 10-20^{\circ} \mathrm{S}$ latitude near the Early Paleozoic south-equatorial Laurentian margin (peri-Laurentian sequences), rocks containing approximately coeval Celtic brachiopod fauna originated in intra-oceanic islands and arc systems at $\sim 30-60^{\circ} \mathrm{S}$, far to the south near the Avalon side of Iapetus (peri-Avalonian sequences). On this basis, in New England and New Brunswick the RIL must lie somewhere west of rock sequences containing Celtic brachiopods (Neuman, 1984, Fig. 2): (1) in the Tetagouche Group of the Miramichi anticlinorium (Fig. 1, MA), New Brunswick, having a paleolatitude of $\sim 53^{\circ}$ $\mathrm{S}$ (Liss et al., 1993); and (2) in the Shin Brook Formation of the Lunksoos anticlinorium (LSA), Maine, with a likely (but undetermined) similar paleolatitude (see Wellensiek et al., 1990; Neuman, 1991). Wellensiek and others did, however, obtain an apparently valid paleolatitude of $\sim 20^{\circ} \mathrm{S}$ for unfossiliferous volcanics in the LSA that they informally named Stacyville volcanics, of presumed Middle Ordovician (pre-Caradoc) age. If one accepts a high south-latitude origin for the Shin Brook, and both a low south-latitude and a Middle Ordovician age (Fig. 5) for the Stacyville, the RIL is reasonably placed somewhere between rocks mapped as Shin Brook and Stacyville within the LSA, as very tentatively shown in Fig. 1. However, Neuman's mapping (1967) in the LSA does not indicate an obvious site for the RIL, nor does it show that any of the rocks shown as Stacyville in Fig. 1 of Wellensiek et al. (1990) actually underlie the fossiliferous late Middle to early Late Ordovician (early Caradocian) Wassataquoik Chert. Instead, in Fig. 2 of his 1984 paper, Neuman shows his unnamed volcanics as coeval with the Wassataquiok.

Age is crucial. As shown in Fig. 5, earliest to latest Middle Ordovician (>470 Ma to $<460 \mathrm{Ma}$ ) is enough time for closure of Iapetus, having an estimated width of 3000-4000 km (Harper et al., 1996, p. 301), at a normal rate of convergence. Therefore, a peri-Avalonian terrane bearing early Middle Ordovician rocks of the Tetagouche Group and the Shin Pond Formation could have migrated northward to the vicinity of the Laurentian margin in time for late Middle and Late Ordovician eruption of the volcanics of a terrane bearing the Bluffer Pond and Winterville Formations, with paleolatitudes of $\sim 18^{\circ}$ and $11^{\circ} \mathrm{S}$ (Potts et al., 1993, 1995) and a ScotoAppalachian fauna, and perhaps all the Stacyville volcanics as well. Reduction of faunal contrast between the middle to high south-latitude Celtic fauna and the younger south equatorial Scoto-Appalachian fauna occurred during this approximate time span (Neuman et al., 1989, p. 378). Accordingly, strata bearing ScotoAppalachian deposits, characteristic of the North American miogeocline, might have covered the RIL after closure, and do in fact occur above rocks bearing Celtic fauna on the peri-Avalonian Gander terrane of this paper (Neuman, 1984, Fig. 2).

Possibly the only paleontological western constraint for the RIL in Maine is the Middle Ordovician brachiopod fauna of the Kennebec Formation, exposed a few kilometers south of Moosehead Lake in the Lobster Mountain anticlinorium (LMA). According to Boucot (1973, pp. 1-3) the Kennebec contains brachiopods characteristic of the Appalachan realm and unlike those of northern Europe. We therefore tentatively place the RIL east of the LMA.

As previously noted, the primitive sponges that were recovered from black slate in the Hurricane Mountain Formation cannot be used to date the formation more precisely than Cambrian or Ordovician, or to identify the terrane in which they originated. Although Neuman et al. (1989) considered them to be Cambrian in age and probably associated with the Gander terrane (Neuman et al., 1989, p. 378, Fig. 1, Cambrian-5), according to R.M. Finks (oral commun., 1982, 1983) similar forms also occur at Metisse sur Mer on the northwest shore of the western Gaspé, Quebec, a few kilometers south of Logan's line and unequivocally on the Laurentian margin.

\subsubsection{Contributions of common lead data}

Ayuso and Bevier (1991) and Ayuso (1986) have shown that feldspar lead isotopic compositions in granitic plutons of the northern Appalachian region help to define basement terranes by determining the $\mathrm{Pb}$ isotopic composition of crustal sources from which the magmas were derived. Ayuso and Bevier identified a northwestern group of plutons having least radiogenic $\mathrm{Pb}$ isotopic signatures (Laurentian origin), a southeastern group, near the Atlantic coast, having most radiogenic signatures (Avalonian origin), and a central group having intermediate signatures.

One of several plutons of the northern group is the Late Ordovician Attean pluton (Fig. 2, SO1), which intrudes the Chain Lakes massif and has the least radiogenic signature of Grenville basement and the massif. As discussed later, we consider the Chain Lakes as periLaurentain basement of our terrane 2 (Fig. 1). In contrast, southeastern plutons of New Brunswick define a peri-Avalonian basement of our terrane 3, and those of coastal New England occur within our composite Avalon and adjacent peri-Avalonian AV (Fig. 1).

In order to refine basement terrane boundaries within and near the area of Fig. 2, common lead isotopic ratios were determined on feldspars from ten plutons, plus two 
members each of the Highlandcroft and Oliverian Plutonic Suites that occur along the axis of the Bronson Hill anticlinorium in northern New Hampshire (samples provided by J.B. Lyons and G.W. Leo). The data are listed in Table 2 and are illustrated in Fig. 6. As shown in Fig. 6, data from twelve plutons in our study area correspond quite closely with the field of results determined for plutonic rocks in the Central Maine province of Ayuso (1986). Ayuso (1986) and Ayuso and Bevier (1991) suggested that the isotopic ratios in the Central Maine province are the result of mixing of lead from Grenville-type $(\approx 1.0-1.2 \mathrm{Ga})$ basement (their Northern Maine group) and Avalonian-type $(\approx 0.60-0.65 \mathrm{Ga})$ basement (their Coastal Maine group). We suggest, however, that their data for the Central Maine province results from mixing of lead in sedimentary aprons that spread oceanward from peri-Laurentian (including Grenville) and peri-Avalonian terranes, rather than from the actual basements. Given the almost complete lack of inheritance in zircon from the plutonic rocks dated in our study, we suggest that these plutons represent partial melts of such oceanic sediments. This possibility might help to resolve an inconsistency revealed by the lead-isotope data of Slack et al. (1991) from volcanogenic massive-sulfide (VMS) deposits in the study area.

Lead isotopes in galena from volcanogenic massive sulfide (VMS) deposits have been cited as clues to accreted terrane identification (Slack et al., 1991). This approach works well in regions, such as northern New Brunswick, where VMS and plutonic feldspars both yield strongly radiogenic leads that are characteristic of the underlying Gander terrane and of Avalon and associated terranes (Slack et al., 1991; Ayuso and Bevier, 1991). In northern New Hampshire, however, VMS and plutonic feldspar $\mathrm{Pb}$ isotope compositions do not agree. Slack et al. (1991) obtained Pb-isotope data from VMS deposits throughout the northern Appalachians, including three deposits in the study area (Fig. 1): The Hampshire Hills prospect and Milan mine (Fig. 4B, $X^{\mathrm{h}}$, $\mathrm{X}^{\mathrm{m}}$ ), hosted by Middle Ordovician Ammonoosuc Volcanics, and the Gardner Mountain (Paddock) mine (Fig. $\left.4 \mathrm{C}, \mathrm{X}^{\mathrm{g}}\right)$, hosted by Silurian to Early Devonian volcanicbearing siliciclastic deposits. These three deposits are assumed to have the Middle Ordovician and SilurianDevonian ages of their host formations. In contrast, the nearest Middle and Late Ordovician and Devonian plutons of the same area (Table 1, Cambridge Black, Chickwolnepy, Jefferson trondhemite, Umbgog, French Pond) have less radiogneic feldspar $\mathrm{Pb}$ isotope compositions that are characteristic of Ayuso and Bevier's intermediate group of plutons; as discussed below, one (Early Silurian Lost Nation) has the least radiogenic $\mathrm{Pb}$ isotope composition more characteristic of Laurentia, or the northern Maine province of Ayuso (1986).
Although this discrepancy is difficult to explain, it is important to consider that VMS-lead, derived from hydrothermal circulation during VMS sea-floor mineralization, might differ from igneous feldspar-lead, derived from melted basement. A similar problem exists in northern Maine, where the small $(15 \times 16 \mathrm{~km})$, Silurian(?), VMS-bearing Bald Mountain terrane (BMT), with $\mathrm{Pb}$ and $\mathrm{Nd}$ isotopes indicative of peri-Gondwanan affinity (Slack et al., 1999). The BMT is a thick sequence of primitive arc volcanics and overlying continental volcanics that is faulted against within-plate basalts of the older Winterville Formation. The Gondwana-like isotopic signature of the BMT is comparable to that of the Hampshire Hills, Milan, and Gardner Mountain VMS deposits, but all of these VMS-bearing sequences occur in regions where plutons have Grenville-like or intermediate feldspar $\mathrm{Pb}$ isotope compositions (Ayuso and Bevier, 1991, Fig. 2). Although the BMT might be truly exotic (thrust over?) relative to the Winterville, as suggested by Slack et al. (1999), the BMT volcanics might alternatively have been deposited above the Winterville and subsequently downfaulted against the Winterville. More research is needed to resolve the discrepancy between VMS-lead and plutonic feldspar-lead in this region.

Lead isotope data from the Lost Nation pluton are less radiogenic than data from all other plutons in our study (Fig. 6; Table 1), but are similar to data from rocks in the Northern Maine province of Ayuso (1986). We infer that the boundary between Ayuso's Northern Maine and Central Maine isotopic provinces probably extends southwest from Maine into New Hampshire east of the Lost Nation pluton.

In contrast, $\mathrm{Pb}$ isotope data from the Early Devonian Fairlee pluton and the Bethlehem and Kinsman Granodiorites are more radiogenic than data from all other plutons in the study area, but are similar to results from rocks in Ayuso's (1986) Coastal Maine province (Table 2; Fig. 6, F, B, K). The Fairlee, not shown on our maps, is located about $10 \mathrm{~km}$ southwest of $44^{\circ} \mathrm{N} 72^{\circ} \mathrm{W}$ (Fig. 2). The Fairlee, Bethlehem and Kinsman bodies are coeval in the approximate range of $410 \pm 10 \mathrm{Ma}$ (Table 1; Kohn et al., 1992; Lyons et al., 1997), and the Bethlehem and Kinsman plutons are interpreted as folded remnants of originally subhorizontal sheets with apparent sources east of the Bronson Hill axis (Lyons et al., 1997, section $\left.\mathrm{B}-\mathrm{B}^{\prime}\right)$. Mapping and structure sections indicate that the Fairlee, on the west side of the Triassic Ammonoosuc normal fault, is a downdropped slice cut from the westernmost Bethlehem remnant, east of the fault (Moench, 1990, Figs. 2 and 3). The strongly radiogenic lead signatures of these rocks therefore suggest the presence of Avalon-type basement of terrane 3 (Fig. 2, T3) east of the Bronson Hill axis at least by earliest Devonian time. 


\subsubsection{Contributions of detrital and xenocrystic zircon ages}

Aleinikoff (in Moench et al., 2000) obtained a typical Grenville age of $\sim 1075 \mathrm{Ma}$ (U-Pb SHRIMP) from a single xenocrystic zircon grain from Jim Pond keratophyre, as well as an age of $484 \pm 5 \mathrm{Ma}$ from 17 igneous zircon grains. One xenocrystic grain, of course, could be a contaminant. Additionally, van Staal et al. (1996) found that Grenville-like ages also occur in Gander basement (see T3 description) and their presence does not automatically prove a Grenville provenance. However, 600-650 Ma ages are common in Gander and Avalon basements (van Staal et al., 1996; Hepburn et al., 1995 , p. 357) whereas such ages are uncommon in true Grenville basement.

Using the $\mathrm{Pb}-\mathrm{Pb}$ evaporation method of dating single zircon grains, Karabinos and Gromet (1993) found that the Moretown Member contains detrital zircon grains that range in age from $550 \mathrm{Ma}$ (late Neoproterozoic) to $2156 \mathrm{Ma}$ (Early Proterozoic). Of nine analyzed zircon grains, three yielded ages of 1003-1134 Ma, typical of grains shed from exposed Grenville-age rocks. According to Karabinos and Gromet (1993, p. 4262) the data set indicates "a predominantly Laurentian provenance for the Moretown Member".

As noted in the description of the flysch sequence, the Dead River Formation of New Hampshire and western Maine is similar in sedimentary style, composition, and age constraints to the Moretown Member of Vermont, and are reasonable correlatives. Accordingly, a Laurentian provenance for the Moretown should apply as well to the Dead River.

\subsubsection{Summary}

Faunal data yield two definitive control points for placement of the RIL in Maine. One is the early Middle Ordovician (late Arenig) Celtic fauna of the Shin Brook Formation of the Lunksoos anticlinorium (Neuman, 1984). The other is Middle Ordovician Applalachian brachiopod assemblage of the Kennebec Formation in the Lobster Mountain anticlinorium (Boucot, 1973; Neuman, 1984). In Fig. 1, both RIL alternatives are placed between these localities. Although the late Middle and Late Ordovician Bluffer Pond Winterville Formations have yielded low south-equatorial paleolatitudes (Potts et al., 1993, 1995), their Scoto-Appalachian fauna do not help to identify their position relative to the RIL because the within-plate basalts of these units might have erupted across the RIL after Iapetus closed. The same applies to the Scoto-Appalachian brachiopod fragments that occur in approximately the same horizon of the Partridge Formation as the C. bicornis zone graptolites (Fig. 4A, site 2; Harwood, 1973; Neuman, 1984; Neuman et al., 1989). The Cambrian or Ordovician primitive sponges of the Hurricane Mountain Formation are more likely to have grown on the Laurentian margin than on the other side of Iapetus, as commonly assumed by other researchers.

Plutonic feldspar-lead isotope data have provided a broad regional framework for basement terrane identification (Ayuso and Bevier, 1991), and they are specifically that the latest Ordovician to Early Silurian Lost Nation pluton on the west side of the Bronson Hill axis was partly derived from Grenville-like basement, whereas the Early Devonian Fairlee-Bethlehem-Kinsman suites were derived from Avalon-like basement east of the BHA axis. Accordingly, it is reasonable to place the RIL either near the Silurian tectonic hinge along the western margin of the Central Maine-Matapedia trough, or within the trough (Fig. 1, RIL and RILa). However, lead isotopes from VMS deposits in northern Maine and northern New Hampshire (Slack et al., 1991, 1999) are inconsistent with feldspar-lead compositions for nearby Ordovician to Devonian plutons. A very tentative alternative position, RILa, is shown in Fig. 1 west of the small Bald Mountain terrane in northern Maine, with Gondwana-like $\mathrm{Pb}$ and $\mathrm{Nd}$ signatures (Slack et al., 1999); but see the discussion in "Contributions of common lead data".

A Laurentian source for the Moretown Member of the Mississquoi Formation of Vermont, indicated by evaporation-method $\mathrm{Pb}$ evaporation ages of zircons (Karabinos and Gromet, 1993), probably applies as well to the Dead River Formation and the conformably overlying Ammonoosuc Volcanics of western Maine and northern New Hampshire. This interpretation is supported by the single Grenville-age xenocrystic zircon from the Jim Pond Formation, but more data are needed. Data from all available sources, however, permit placement of the RIL east of exposures of the Ammonoosuc sequence along the northern BHA.

A different approach is provided by a recent attempt to distinguish basement sources on the basis of geochemical characteristics of Devonian plutons in northern New England (Dorais and Paige, 1999). According to these authors, several metaluminous Devonian plutons have sources in Grenville-type basement ( $G$ in Fig. 2 ), whereas a Devonian pluton and a Carboniferous pluton (A in Fig. 2) have sources in Avalon-type basement. The close juxtaposition of Dorais and Paige's G-source and A-source plutons southeast of the Bronson Hill axis eliminates the need for the intermediate basement inferred by Ayuso and Bevier (1991). It may also provide tight control for placing the RIL southeast of the Bronson Hill axis, as shown in Fig. 2 (RILa).

If the RILa is extended south to Massachusetts, it would approximately coincide with Skehan's placement of the boundary between Laurentian and Gondwanan basements (our RIL) just east of the Bronson Hill axis (Skehan, 2001, Figure in p. 14). This location, if correct, is necessarily very approximate, but it can be modified to accommodate four of possibly several small ultra- 
mafic soapstone bodies that occur in a north-trending belt in central New Hampshire about $40 \mathrm{~km}$ east of the Bronson Hill axis (Lyons et al., 1982; Lyons et al., 1997). These bodies are probably diapiric in origin, possibly derived from a plate suture (the RIL?) buried by the Late Ordovician to Early Devonian deposits of the Central Maine-Matapedia trough.

\subsection{Terranes 1 and 2-composite Notre Dame terrane and Baie Verte-Brompton and Boil Mountain lines}

Terrane 1 (Fig. 1, T1) contains the Early Ordovician ophiolite complexes of Quebec, associated melange mapped as the St. Daniel Formation, and regionally metamorphosed rocks of the Neoproterozoic(?) Chain Lakes massif and correlative Chain Lakes blocks in St. Daniel melange (Boone and Boudette, 1989, p. 22; Cousineau, 1991; Malo et al., 1992). The delineation of terrane 1 in Fig. 1 approximately corresponds to the Boundary Mountains terrane of Boone and Boudette (1989, Fig. 4B), also termed the Chain Lakes terrane by Skehan and Rast (1995, Fig. 1). Terrane 2 (T2) consists of the ophiolitic Boil Mountain Complex and Jim Pond Formation, melange of the Hurricane Mountain Formation of Maine, and the Ottaquechee and Stowe Formations of Vermont, containing dismembered mafic-ultramafic bodies. Available evidence, discussed later, suggests that both $\mathrm{T} 1$ and $\mathrm{T} 2$ are peri-Laurentian and broadly equivalent to the Notre Dame terrane of Newfoundland.

As shown in Fig. 1, T1 is bounded on the northwest by the Baie Verte-Brompton line (BBL) and on the southeast by the Boil Mountain line (BML); both lines are interpreted as the traces of originally southeastdipping plate sutures between Laurentia (LA) and terranes 1 and 2. The BML is mapped across the Boundary Mountains anticlinorium and is projected westward across the Connecticut Valley trough to a point on the BBL that lies somewhere between the Thetford Mines ophiolite, containing plagiogranite dated at $480 \pm 2 \mathrm{Ma}$ (Whitehead et al., 1996), and the Orford ophiolite to the south, containing trondhjemite dated at $504 \pm 3 \mathrm{Ma}$ (David et al., 1993). We assume that the BML is either truncated by, or joins, the BBL. As discussed below, the BBL probably truncates the apparently slightly older BML. In Vermont south of the Orford body, the BBL suture is more diffuse and dismembered ophiolitic rocks of the Ottaquechee and Stowe Formations occur in a wide belt. One of these, at Belvidere Mountain, has yielded a Cambrian ${ }^{40} \mathrm{Ar} /{ }^{39} \mathrm{Ar}$ plateau metamorphic age of $505 \pm 2 \mathrm{Ma}$ (Laird et al., 1993; Laird, 1996). According to our interpretation, this diffuse segment of the Baie VerteBrompton line (or Cameron's line) marks the truncated western edge of T2. In northern Maine, the southeast edge of $\mathrm{T} 1$ is uncontrolled, but we tenta- tively infer that it is truncated by the Red Indian line in northern New Brunswick (Fig. 1).

By the definition of an accreted terrane given in the lead paragraph of this section, the Dead River Formation and Ammonoosuc Volcanics are not part of T2, because they were deposited over the Boil Mountain-Jim Pond-Hurricane Mountain sequence after the T1-T2 collision. In fact, probable correlatives of the flysch and Ammonoosuc occur in Quebec (older parts of Ascot Complex and Magog Group), above T1. This reasoning may apply as well to the lower member of the Ammonoosuc of the southern BHA, and the Shelburne Falls arc to the west.

The Boil Mountain Complex was thrust northwestward onto the Chain Lakes massif by high temperature ductile faulting (Boudette, 1982). Although the thrusting is not dated, it may have occurred during late Early Ordovician emplacement of the tonalite sill, dated at $477 \pm 1 \mathrm{Ma}$ (Kusky et al., 1997) within the ophiolite, and before deposition of the flysch sequence, interpreted by Boone and Boudette (1989, pp. 19-22) to have been deposited on the Hurricane Mountain Formation "as a carapace over older, tectonically inactive portions of an accretionary wedge".

Using our terrane nomenclature, according to the model of Boone and Boudette (1989), based on data available in the 1980s, the T1-T2 collision occurred perhaps 20-40 m.y. before T1 + T2 (Notre Dame) collided with Laurentia (LA). Age data now indicate that both collisions occurred within Early Ordovician time, albeit probably in the same sequence as that proposed by Boone and Boudette (1989). Whereas the T1-T2 collision probably occurred about when the 477-Ma tonalite sill intruded the $484 \mathrm{Ma}$ Boil Mountain-Jim Pond ophiolite, the T1+T2-LA collision probably occurred 3-15 m.y. after the 480-Ma Thetford Mines ophiolite was obducted over the Laurentian margin (Whitehead et al., 1996). The latter collision was still occurring along the BBL surface when the metamorphic peak was reached at $\sim 470$ Ma (Laird, 1996) along the Green Mountain axis, Vermont, and continued farther west through much of Late Ordovician time (see Karabinos et al., 1998; and discussions by Ratcliffe et al., 1999; and Karabinos et al., 1999). As discussed in the next section, Iapetus probably closed along the RIL rather early in Late Ordovician time.

\subsection{Terrane 3-exploits-Gander terrane and Brunswick subduction complex}

Terrane 3 (T3), east of the Red Indian line, is most widely exposed in the northern portion of the Miramichi anticlinorium, New Brunswick (Fig. 1, MA), where it has been studied most recently by van Staal (1994); van Staal et al. (1996) and Whalen et al. (1997). To summarize, T3 (of this paper) in New Brunswick is 
composed of three interfolded and interfaulted petrotectonic belts, now distributed north to south, but originally northwest to southeast before Acadian dextral faulting. On the northwest is the Popelogan arc (Balmoral Group arc volcanics), interpreted as a late Early to Middle Ordovician continental arc on the peri-Avalonian Gander margin; it was erupted above a southeast-dipping subduction zone. The Popelogan arc split in Middle Ordovician time to form the Tetagouche back-arc basin (van Staal, 1994; Whalen et al., 1997). These arc and back-arc belts represent the Exploits subzone. The Tetagouche basin received ensimatic ophiolite ( 464 Ma), tholeiitic and alkalic basalt, and dark fine-grained sediments of the Fournier Group on the northwest, and ensialic mixed volcanics and related sediments of the Tetagouche Group on the southeast (van Staal, 1994, Fig. 3). The Fournier Group plus underlying gabbro basement, discussed below, have been thrust eastward over the Tetagouche Group on a surface marked by Late Ordovician and Silurian blueschist and the Belledune River melange (van Staal, 1994, p. 956), thus juxtaposing ensimatic and ensialic parts of the Tetagouche back-arc basin.

Next to the southeast and south is a large area underlain by interbedded sandstone and shale of the Lower Ordovician Miramichi Group, representative of the Gander zone. Conglomerate at the base of the Tetagouche Group channels into Early Ordovician chaotic rocks, the Miramichi melange (van Staal, 1994), at the top of the Miramichi Group. In eastern Maine, however, Allan Ludman (written commun., July, 1998) has mapped probably the same contact as a Penobscottian(?) unconformity. There the Baskahegan Lake Formation (probably $=$ Miramichi) has a more complex history than overlying metasedimentary and metavolcanic rocks correlated to the Tetagouche Group (Ludman, 1991a).

As summarized by van Staal et al. (1996) Gander basement in New Brusnwick, lying below the Mirmachi Group and Tetagouche back-arc basin deposits, is composed of earliest Cambrian (500-550 Ma), Neoproterozoic (600-800 Ma), Mesoproterozoic (1000-1550 Ma) and Archean rocks (2500-2700 Ma). The occurrence of Avalon-like basement in Gander is shown also by the strongly radiogenic $\mathrm{Pb}$-isotope compositions of plutonic feldspars (Ayuso and Bevier, 1991). Of cautionary importance to our tale is the occurrence of Grenville-like U-Pb zircon ages of $\sim 1075$ and $1088+3 /$ -2 Ma for xenocrystic zircon grains in granodiorite cobbles from basal Tetagouche Group conglomerate; these clasts were probably derived from nearby basement (van Staal et al., 1996). van Staal et al. also obtained an age of 543 Ma for the Upsalquitch Gabbro, considered by them as a slice of thinned continental basement, now exposed in the immediate hangingwall of the blueschist-lined fault at the base of the Fournier
Group. The Upsalquitch Gabbro is depositionally overlain by Middle Ordovician MORB-like basalt of the Fournier Group (van Staal et al., 1996, p. 354). These authors state that the Grenville-like ages of xenocrystic zircon grains in the cobbles link Gander to the Amazonia portion of Gondwanaland; they stress that such ages do not automatically imply a Laurentian provenance (see van Staal et al., 1998, Fig. 7, for the location of Amazonia).

According to our model, the Neoproterozoic Massabesic Gneiss Complex (623 \pm 8 Ma) at the northwest margin of the Merrimack trough (Fig. 1, MG, MT) is a remnant of T3 (Gander) basement. As shown by the Devonian age of metamorphic zircon (Aleinikoff et al., 1995), the Massabesic body was where it is now before or during Acadian metamorphism. This relationship contrasts with the Neoproterozoic Dry Hill Gneiss, which apparently experienced only Alleghanian metamorphism. If so, the Dry Hill was underthrust to its present position in post-Acadian time, and cannot be considered as basement during eruption of the Quimby and Ammonoosuc sequences.

Returning to the coastal belts, the Casco Bay sequence (Fig. 1, CB) is a complex package of metasedimentary and metavolcanic rocks that are divided into several named formations of uncertain regional correlations, discussed by Bothner and Hussey (1999). Some calcareous rocks that were originally included in the Casco Bay sequence (Macworth Formation, part of Cape Elizabeth Formation) are now considered part of the Merrimack Group by Bothner and Hussey (1999). As now restricted, the Casco Bay sequence contains the Cushing Formation (felsic to local mafic metavolcanic rocks and calcareous and sulfidic metasedimentary rocks) and a structurally or unconformably overlying succession that includes the Cape Elizabeth Formation (noncalcareous metawacke and metapelite), the Spring Point Formation (mafic to felsic metavolcanics and volcanogenic metasedimentry rocks), and four overlying metasedimentary units. Volcanics of the Cushing have yielded $\mathrm{Pb}$ zircon ages of $471 \pm 3$ and $443 \pm 2 \mathrm{Ma}$ (Hussey and Bothner, 1995, p. 211). We tentatively propose that the Casco Bay sequence belongs to $\mathrm{T} 3$ and at least the older part relates to the Tetagouche Group of New Brunswick.

In the Lunksoos anticlinorium (Fig. 1, LSA) it is tempting to place the Gander margin at the contact between the Grand Pitch Formation, which contains the Cambrian(?) trace fossil Oldhamia smithi, and the unconformably overlying lower Middle Ordovician (upper Arenig) Shin Brook Formation, on the basis of available descriptions and paleontologic age data (Neuman, 1967, 1984, 1987, 1991; van Staal, 1994). Whereas the Grand Pitch, a mainly thinly bedded shale-quartzite sequence, might be considered a relatively distal turbidite facies of the Miramichi Group, the volcanic and volcaniclastic 
rocks of the Shin Brook are reasonably interpreted as facies of the basal rocks of the Tetagouche Group.

Additionally, the Shin Brook-Grand Pitch unconformity in the Lunksoos anticlinorium is the type locality of the Penobscot orogeny (Neuman, 1987). Because this event occurred in the approximate area of $53^{\circ} \mathrm{S}$ (Mac Niocaill et al., 1997), it cannot have much bearing on tectonic events in peri-Laurentian terranes that were some 30-40 degrees of latitude to the north in late Early Ordovician time.

The Brunswick subduction complex of northern New Brunwick (Fig. 1, BSC) "incorporates all allochthonous Lower Silurian, Ordovician, and older rocks in the northern Miramichi Highlands and surroundings" (van Staal, 1994, p. 946). It is a zone of Late Ordovician and Silurian southeast-vergent thrust faults, related folds and fabric elements, and plutons that developed in Ordovician rocks of the Tetagouche back-arc basin and the Gander margin. Local high-pressure metamorphism is expressed by the blueschist layer along the basal Fournier fault, of mainly Silurian age and of southeast vergence. According to van Staal (1994), the subduction zone dipped northwest (opposite to the earlier Ordovician polarity) and developed within the Tetagouche basin. For reasons given in the next section, we propose that the actual subduction boundary is buried beneath deposits of the Fredericton-Merrimack trough to the southeast where it is shown as the New Brunswick line (Fig. 1, NBL).

\subsection{Fredericton-Merrimack trough and New Brunswick line}

The Fredericton-Merrimack trough (Fig. 1, FT, MT), containing unfossiliferous, variably calcareous, fine-grained metasedimentary rocks of probable Late Ordovician and Silurian age, lies between terrane 3 and the composite Avalon and adjacent peri-Avalonian terranes (AV). Although now divided by an arch exposing older, more strongly metamorphosed rocks of the Casco Bay belt (Fig. 1, CB), Hussey et al. (1999) inferred that rocks of the trough originally extended continuously from northeastern Massachusetts, where it is truncated by the Clinton-Newberry fault, at least to central New Brunswick, where it is now covered by Carboniferous-Triassic deposits. Deposits of the trough are not recognized in Cape Breton Island and Newfoundland, however, where the Exploits + Gander belt is faulted against Avalon (Dubé et al., 1996); we suspect the trough existed there prior to Acadian faulting.

The Merrimack portion of the trough (MT) is the site of deposition of the Merrimack Group (Lyons et al., 1982), which consists of the Kittery, Eliot, and Berwick Formations, described by Bothner and Hussey (1999). The Fredericton portion (FT) contains the Bucksport and Appleton Ridge Formations in coastal Maine, and the Flume Ridge, Digdeguash, and Pocomoonshine Lakes Formations in eastern Maine and southwestern New Brunswick. Although primary sedimentary and compositional features differ among all these units, they represent a cohesive package of generally fine grained marine sedimentary deposits (Hussey et al., 1999).

The local presence of conglomerate on the southeast side of the Fredericton trough (Ludman et al., 1993, p. 7) and a faulted unconformity on the northwest side (van Staal, 1994, p. 950) suggests sedimentary linkage to T3 and AV. Ludman et al. (1993) and Hepburn et al. (1995, p. 360) proposed that the Fredericton and Merrimack deposits accumulated directly on oceanic crust, in an ocean basin, here called the "Fredericton sea", that lay between $\mathrm{T} 3$ and $\mathrm{AV}$ of this paper; the basin narrowed through Silurian time and the subsequent Early Devonian collision caused the Acadian orogeny. The main difference between our interpretation and that of van Staal (1994) and van Staal and de Roo (1995) is: Whereas they view the Gander basement and Avalon as a single continental plate (van Staal, 1994, Fig. 8), we view the Gander basement and Avalon as separate plates, at least the latter composite, and all sliced from Gondwanaland. According to our view, before the Acadian collision, Gander (of T3) and AV were separated by the "Fredericton Sea".

What is the evidence for the "Fredericton sea"? As summarized by Neuman et al. (1989, pp. 80,81$)$, postOrdovician brachiopod and ostracode faunas show a continuing faunal isolation of Avalon from the Laurentian margin (also see Copeland and Berdan, 1977; Shride, 1976). Boucot (1993, p. 47) stressed that "there must be a very important tectonic boundary that juxtaposes an eastern Coastal Acadia block with European biogeographic affinities to a terrane with North American biogeographic affinities". He continued: "In New Brunswick, this boundary must be located to the northwest of the Long Reach-Mascarene area and to the southeast of the isolated, most southeasterly known Eastern Americas Realm (Devonian) fossil locality". That locality is near the southeast edge of T3 of this paper, about $70 \mathrm{~km}$ west of Fredericton, New Brunswick.

Citing other sources, Ludman et al. (1993, p. 77) similarly stressed the importance of the Fredericton trough as a faunal barrier, and he cited paleomagnetic evidence of at least $20^{\circ}$ of latitude separation between Avalon and the Laurentian margin in Early Silurian time. Although van Staal and de Roo (1995, pp. 383384) interpreted the Fredericton trough as a foreland basin on the Gander margin, they did not address the above-cited faunal and paleomagnetic evidence for the "Fredericton Sea". Nor did Bradley et al. (1998) or van Staal et al. (1998).

Following Ludman et al. (1993, Fig. 10), we propose that Late Ordovician to earliest Devonian subduction 
occurred on opposite sides of the "Fredericton sea". Hepburn et al. (1995) supported this model, and Bradley (1983) proposed a remarkably similar model for his "Merrimack" trough (now termed the Central Maine trough), including the Fredericton-Merrimack trough of this paper. Whereas northwestward subduction below T3 produced the Brunswick subduction complex, southeastward subduction below the Avalon and adjacent peri-Avalonian terranes (AV) produced the proposed Penobscot subduction complex and the coastal volcanic arc (Fig. 1, PSC, CVB), discussed in the next section. As the sea closed, its sediments were folded, but probably not significantly metamorphosed, before emplacement of the Late Silurian (423 Ma) Pocomoonshine gabbro-diorite (West et al., 1992, 1995).

According to our model, the Acadian orogeny occurred after the opposed subduction zones occluded (analogous to occluded fronts in weather systems) below the trough, along the proposed New Brunswick line (Fig. 1, NBL), now buried by Silurian sediments of the trough. Soesoo et al. (1997) proposed an essentially identical model for the Paleozoic Lachlan fold belt, Australia. Perhaps the small, $>412$ Ma Berry Brook gabbro-diorite found recently near the center of the FT (Ludman et al., 1993), represents a final mafic intrusion derived from the sinking occluded plates (see Soesoo et al., 1997, Fig. 1E). Later dextral faulting along the Norumbega fault system (Fig. 1) might have truncated the Brunswick subduction complex, evidence for which is lacking northwest of the Fredericton-Merrimack trough in the Penobscot Bay area of coastal Maine (West et al., 1995) or farther southwest.

\subsection{Composite Avalon and adjacent peri-Avalonian} terranes, Penobscot Bay subduction complex, and coastal volcanic arc

\subsubsection{Avalon "proper"}

Skehan and Rast (1995, p. 208) characterized the Boston Avalon terrane "as a Late Proterozoic magmatic arc built on continental crust and overlain unconformably by Cambrian to Ordovician strata bearing Avalon realm fossils". The sedimentary cover remained largely unmetamorphosed until Late Paleozoic time (Wintsch et al., 1992, 1993). The gneissose Precambrian basement is intruded by Neoproterozoic plutons. Rocks of Avalon are also exposed in southernmost New Brunswick (van Staal et al., 1996; Barr and White, 1991), and, of course, on the Avalon Peninsula, Newfoundland. As summarized by Hepburn et al. (1995, p. 357), volcanic and plutonic rocks having ages of 600-650 Ma are characteristic of Avalon and dominate Avalon of southeastern New England. In the Canadian Appalachians, our Avalon "proper" contains two distinctive amalgamated terranes (van Staal et al., 1996, p. 350, and references).
Just east of the Massachusetts shore is a belt of rock thought to be a continuation of the Meguma zone of Nova Scotia (Skehan and Rast, 1995, Fig. 1). Meguma is composed of enormously thick Early Paleozoic turbidites, underlain by basement of uncertain character, and unconformably overlain by shallow marine sedimentary and bimodal volcanic rocks of Silurian and Devonian age (Keppie, 1989).

\subsubsection{Peri-Avalonian terranes distinct from Avalon}

AV of this paper (Fig. 1) also contains other faultbounded peri-Avalonian belts that lie between Avalon and the Fredericton-Merrimack trough, but are geologically distinct from Avalon "proper". One is the Putman-Nashoba belt of eastern Connecticut and Massachusetts (Fig. 1, NS), discussed below. Others (not necessarily Nashoba correlatives) are: (1) the St. Croix belt of Maine and New Brunswick, a fossil-bearing, Cambrian(?) to Upper Ordovician sequence of sedimentary rocks and local basalt-dominated volcanics (Fyffe et al., 1991, pp. 25-31; Ludman, 1991a), unconformably underlain, in the western Penobscot Bay area, by Neoproterozoic rocks of the Islesboro-Rockport belt (West et al., 1995, p. 1847); (2) the Cambrian, predominantly sedimentary Ellsworth belt of Maine, containing a tuff bed dated at $509 \pm 1 \mathrm{Ma}$ (Stewart et al., 1993, 1995). West et al. (1995) demonstrated that the St. Croix rocks were regionally deformed, metamorphosed, and intruded by plutons in Silurian time, and were thrust westward by the Acadian Sennebec Pond fault (Fig. 1, SP) over rocks of the Fredericton trough, which were metamorphosed only in Devonian time.

The Putnam-Nashoba belt is composed of metamorphosed Late Cambrian and Ordovician(?) to Silurian arc-volcanic and sedimentary rocks that were strongly deformed and metamorphosed in Late Ordovician(?) and Silurian time, and intruded by Silurian and Devonian to Carboniferous plutons; it lacks conclusive evidence of Neoproterozoic basement (Hepburn et al., 1995). Pertinent U-Pb ages reported by Hepburn et al. (1995) are 499 +6/-3 Ma for the metavolcanic Fish Brook Gneiss, and a metamorphic monazite age of $425 \pm 3 \mathrm{Ma}$ from the same body. Zartman and Naylor (1984) previously reported an age of $430 \pm 5 \mathrm{Ma}$ for the Sharpners Pond Diorite in the Nashoba.

According to Hepburn et al. (1995, p. 358) the fact that evidence for $\sim 600 \mathrm{Ma}$-age zircons were found only in the youngest pluton that they dated (Indian Head Granite; U-Pb lower intercept $349 \pm 4 \mathrm{Ma}$, upper intercept $605+200 /-180 \mathrm{Ma}$ ) suggests that PutnamNashoba rocks originated far from Avalon, and did not receive Avalonian detritus until the Carboniferous. This interpretation is consistent with the view (Wintsch et al., 1993, p. H-9) that Alleghanian metamorphism of Avalon occurred at a site that was far distant from its present position adjacent to the Putnam-Nashoba belt. 
Alternatively, as discussed in the next section, the Putnam-Nashoba and Avalon belts may represent separate terranes that were linked before Silurian to Early Devonian eruptions along the coastal volcanic arc (Fig. 1, CVA).

Hepburn et al. (1995, p. 358) tentatively correlated the Putnam-Nashoba rocks to the Cushing Formation of the Casco Bay belt (Fig. 1) and Zen (1989) included the Putnam-Nashoba in his Nashoba-Casco-Miramichi terrane. We prefer, however, to consider the Putnam-Nashoba, St. Croix, and perhaps Ellsworth as the same lithotectonic belt, based on the Late Cambrian ages cited above for the Ellsworth and the Fish Brook Gneiss of the Putnam-Nashoba belt, as well as the cited evidence of Silurian metamorphism, deformation, and plutonism in the Putnam-Nashoba and St. Croix belts. In contrast, only Middle to latest Ordovician ages $(471 \pm 3,443 \pm 2 \mathrm{Ma})$ have been obtained so far from the Cushing Formation, considered the basal unit of the Casco Bay sequence (Hussey and Bothner, 1995, p. 211).

We follow Skehan and Rast (1992), who "suggest that the combined Putnam-Nashoba (and, we add, likely correlatives) and Avalon (proper) terranes represent different aspects of the Avalon Superterrane". They are all peri-Gondwanan, but each split separately either before or after they left Gondwanaland.

\subsubsection{Coastal volcanic arc}

Thick sequences of weakly deformed and largely unmetamorphosed Silurian and Lower Devonian volcanic rocks occur in northeastern Massachusetts, along coastal Maine, and in southern New Brunswick. These rocks are abundantly fossiliferous, having Baltic-British fauna rather than Appalachian fauna (Boucot, 1993). The Massachusetts portion is represented by the fossiliferous Upper Silurian to Lower Devonian Newbury Volcanic Complex, exposed in a fault slice along the Nashoba-Avalon boundary (Fig. 1, CVA). The Newbury contains abundant andesite and related calcalkaline volcanics (Shride, 1976) of continental arc character (McKenna et al., 1993). Although exposures preclude determination of the original terrane association, the Newbury is reasonably inferred to be the volcanic expression of calc-alkalic intermediate to granitic Silurian and Early Devonian plutonism in the Putnam-Nashoba belt (Hepburn et al., 1995, p. 361; references therein). In eastern Maine and southern New Brunswick, volcanics of the belt are a bimodal sequence of basalt, rhyolite-dacite, very sparse andesite, and granite and gabbroic plutons (van Wagoner et al., 1988; Gates and Moench, 1981; Seaman et al., 1995). In New Brunswick, the volcanic belt is represented by the Early Silurian to Early Devonian Mascarene cover sequence, which unconformably overlies rocks of Avalon to the southeast and overlaps the St. Croix terrane to the northwest (Fyffe et al.,
1991, pp. 22-23). In eastern Maine, a distal facies of the volcanic belt unconformably overlies St. Croix beds (Ludman, 1991b, references therein).

Gates and Moench (1981) and others argued for an extensional non-arc setting for the coastal volcanic belt. However, hafnium, thorium, and tantalum data contained in that report suggest that the basalts are calc-alkaline (J.F. Slack, written commun., 1985); additionally, Ludman et al. (1993, p. 77) suggested an Andean setting, a view that we now favor, also supported by a recent petrochemical study (Llamas and Hepburn, 2001). The strong bimodality of the CVB may have been a product of intra-arc extension resulting from subduction rollback during closure of the "Fredericton Sea". As such, the coastal volcanic belt can be viewed as a magmatic arc above a southeast-dipping subduction zone represented by the proposed Penobscot Bay subduction complex (see below).

\subsubsection{Penobscot Bay subduction complex}

As proposed here, the Penobscot Bay subduction complex (Fig. 1, PSC) is expressed by Silurian dynamothermal metamorphism and magmatism, and northwestward structural vergence in the St. Croix belt (West et al., 1995). Northwest vergence is indicated by "early kilometer-scale, northwest-directed thrusts and recumbent folds" (West et al., 1995, p. 1847, and references therein). This polarity contrasts with the southeastward vergence of Late Ordovician and Silurian tectonism within the Brunswick subduction complex (Fig. 1), west of the Fredericton trough. Silurian metamorphism, deformation, and plutonism in the Putman-Nashoba belt (Hepburn et al., 1995) can be regarded as a manifestation of the Penobscot Bay subduction complex, although these authors do not report the Silurian structural vergence in the Nashoba.

\section{Speculative accretionary and interaccretionary events}

For the purpose of this paper, the tale begins probably in Late Cambrian time $(\sim 500 \pm 5 \mathrm{Ma})$ when the Notre Dame arc of Newfoundland and our terranes 1 and 2 lay well south of the Laurentian shore (Early Paleozoic coordinates), long after the rift-drift sequence, starting at about $570 \mathrm{Ma}$ (Walsh and Aleinikoff, 1999), that formed Iapetus. Chain Lakes diamictites and related rocks formed during the rifting, and migrated seaward, possibly with an underlying fragment of Grenville crust, to form T1. T2 lay considerably farther offshore to the south. Late Cambrian to Early Ordovician sea floor having geochemical characteristics of marginal basins (Shaw and Wasserburg, 1984; Coish and Rogers, 1987) formed in the basins between T2 and $\mathrm{T} 1$ and the Atlantic-type margin of Laurentia. This produced the ophiolites now exposed along the BBL and 


\section{NORTH}

SOUTH

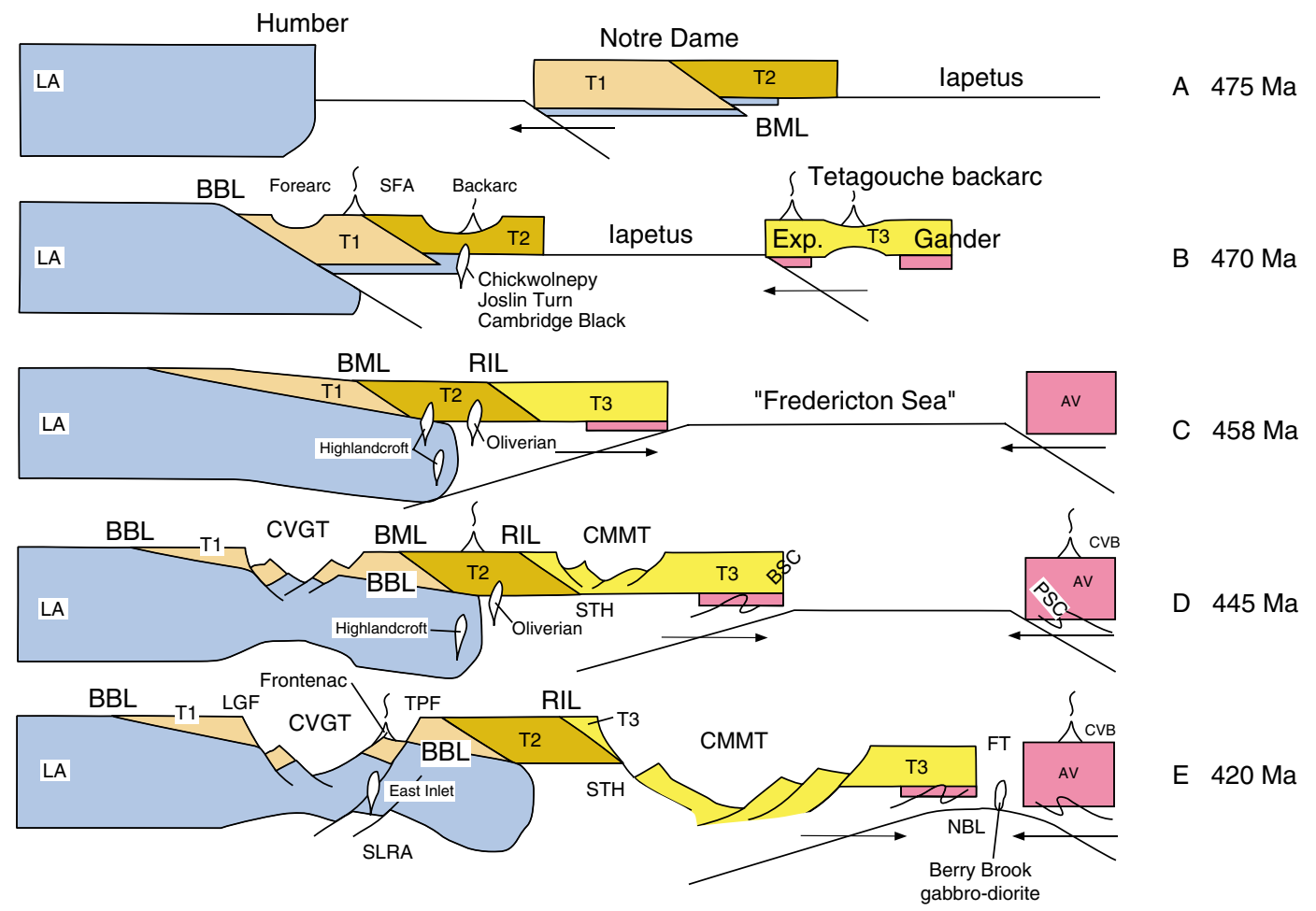

Fig. 7. Proposed tectonic evolution of the northern Appalachians in New England and adjacent Canada. See Fig. 1 for explanation of terrane symbols, and Figs. 1 and 2 for explanation of lines. Horizontal arrows indicate directions of trench rollback.

BML, dated at 505, 484, and $480 \mathrm{Ma}$. The large amount of felsic volcanics in the Jim Pond Formation suggests the presence of sialic basement, possibly Grenville, in the Jim Pond's magmatic source; a Grenville source is tentatively suggested by the occurrence of a Grenvilleage zircon grain in the dated Jim Pond keratophyre. According to geophysical studies, the southeastern Grenville margin now lies near the Silurian tectonic hinge in western Maine and southwestern New Hampshire, but much farther west in northeastern Vermont (see arrows 1, 3, and 2, respectively, in Fig. 1, plotted from Stewart et al. (1993), Ando et al. (1984) and Hughes and Luetgert (1991)).

By $475 \mathrm{Ma}$ (Fig. 7A), the Boil Mountain Complex and the Jim Pond-Hurricane Mountain ophiolitic melange had just been ramped northward, above a southdipping subduction zone, onto rocks of the Chain Lakes massif. This occurred well off the Laurentia shore, but above at least fragments of Grenville and within the North American faunal realm. The suture is the Boil Mountain Line. As suggested by the model of Cawood and Suhr (1992), the ophiolite formed in the overiding plate by extension produced by trench rollback (Royden, 1993a,b). Obduction occurred shortly after ophiolite crystallization while still hot and less dense than old, cold oceanic crust; it may have metamorphosed the massif at high grade. This collision and metamorphism occurred before deposition of the Early to early Middle Ordovician flysch (Boone and Boudette, 1989), perhaps when the $477 \mathrm{Ma}$ tonalite sill (Kusky et al., 1997) was emplaced within the Boil Mountain-Jim Pond ophiolite. [The much-cited $468 \mathrm{Ma}$ monazite age for Chain Lakes (Dunning and Cousineau, 1990) may not be a valid metamorphic age for this event.] Terranes 1 and 2 were thus united along the Boil Mountain suture to form a composite peri-Laurentian $\mathrm{T} 1+\mathrm{T} 2$, probably equivalent to the Notre Dame arc of Newfoundland. The periAvalonian Gander belt (T3) and Avalon and adjacent tracts (AV) were out of sight in cold southern Iapetus, probably as several island belts that were sliced from Gondwana.

Composite $\mathrm{T} 1+\mathrm{T} 2$ continued to travel north toward Laurentia, above a second south-dipping subduction zone (BBL) and at about $470 \mathrm{Ma}$ (Fig. 7B), trench rollback had drawn the leading edge of $\mathrm{T} 1+\mathrm{T} 2$ over the Laurentian margin, but the trailing edge was still at least partly ensimatic. During this collision, Taconian metamorphism of the Laurentian margin west of the BBL peaked at about $470 \mathrm{Ma}$ (Laird et al., 1993; Laird, 1996; Karabinos et al., 1998, 1999). To the east, flysch deposition ended abruptly with the onset of Ammonoosucsequence arc volcanism and plutonism, at first as an 
extensional incipient arc (Fitz, 2002). Strongly evolved granite of the Cambridge Black pluton was produced by partial melting of country rocks by primitive gabbroic magmas now represented by the nearby Chickwolnepy intrusions. These events, dated in the range of $>469-461$ $\mathrm{Ma}$, occurred in a supra-subduction basin produced by extension that was almost parallel to the orogen (Fitz, 2002).

On the assumption that the Ammonoosuc sequence of the Bronson Hill belt and rocks of the Shelburne Falls arc to the southwest belong to the same Taconian arc, the onset of magmatism was probably diachronous: $>469-461 \mathrm{Ma}$ for the Bronson Hill ( 484 Ma for Jim Pond) and 470-475 and 485 Ma for Shelburne Falls (Karabinos et al., 1998). There may also be differences in details of tectonic setting: A boninitic fore-arc setting for the Shelburne Falls-Moretown (Kim and Jacobi, 1996), and for the Ascot-Magog sequence (especially the undated Frontiére and Etchemin Formations of lower Magog) of Quebec (Cousineau, 1994), versus an arc setting, lacking boninites, for at least the $>469-461 \mathrm{Ma}$ Chickwolnepy and Ammonoosuc eruptions (Fitz, 2002).

Southward Taconian subduction probably ended before early Late Ordovician time, no later than about $460 \mathrm{Ma}$, when Ammonoosuc-sequence magmatism ended as abruptly as it began. It was followed by a hiatus of subduction-related magmatism that lasted a few million years. In the northern portion of the Bronson Hill belt, the hiatus is represented by the C. bicornisbearing portion of the Partridge Formation in the Oquossoc area (Fig. 4A) and the common metacherts and silicate iron-formation that occur at the base of the Partridge in the Littleton area (Fig. 4C), as described earlier. In Massachusetts and southwestern New Hampshire, the hiatus may be represented by metacherts that occur between rocks mapped as the upper and lower members of the Ammonoosuc (Schumacher, 1988), here correlated to the Quimby and Ammonoosuc sequences respectively. In Maine to the north, the hiatus may correlate to the lower Upper Ordovician Wassataquoik Chert of the Lunksoos anticlinorium (LSA), and perhaps to the within-plate basalts (Winchester and van Staal, 1994) of the Munsungun-Winterville and Lunksoos anticlinoriums. This hiatus of possibly regional extent may have been a time of reversal of subduction polarity (Karabinos et al., 1998, Fig. 5), perhaps resulting from the aborted subduction of bouyant Laurentian basement.

Meanwhile (Fig. 7B) the peri-Avalonian Gander belt, our terrane 3, with its Avalonian basement and the Popelogan arc on its northern margin, moved northward into view. At about $470 \mathrm{Ma}, \mathrm{T} 3$ rifted to produce the Exploits zone and Tetagouche back arc basin (van Staal, 1994, Fig. 8). As Iapetus narrowed further, T3 acquired Middle to early Late Ordovician Scoto-Appalachian fauna (Neuman et al., 1989; van Staal et al.,
1998, pp. 222-223). By 458 Ma (Fig. 7C), T3 had joined T2 + T1 along the Red Indian line, now buried in New England by Late Ordovician and younger deposits of the Central Maine trough.

Avalon "proper" and adjacent tracts, however, still lay across the "Fredericton Sea" (Fig. 7C) to the south. The existence of the sea is indicated by the persistence of faunal contrasts between Avalon and regions to the northwest into Devonian time (Boucot, 1993; Copeland and Berdan, 1977). We repeat, however, that AV of Figs. 1 and 7 is a composite of unlike terranes, such as Putnam-Nashoba and composite Avalon of southeast New England. The various components of AV may have originated as fragments that were rifted separately from different parts of Gondwanaland and its marginal prism, or from one another.

By $\sim 445 \mathrm{Ma}$ (Fig. 7D), subduction zones of opposite polarity on opposite sides of the "Fredericton Sea" (Ludman et al., 1993, Fig. 10b; Hepburn et al., 1995) produced the now southeast-vergent Brunswick subduction complex on the northwest side and the northwest-vergent Penobscot Bay subduction complex on the southeast side, proposed in this paper on the basis of Silurian dynamothermal deformation and plutonism in the Penobscot Bay area, Maine (West et al., 1995), and perhaps in the Putnam-Nashoba belt of eastern Massachusetts (Hepburn et al., 1995).

To the west, Quimby-sequence magmas represented by the Highlandcroft and Oliverian Plutonic Suites and the volcanic member of the Quimby Formation and its probable correlatives were erupted above the northdipping subduction zone, mainly onto T2. Conceivably, the Mohawkian K-bentonites of interior Eastern North America (Kolata et al., 1996) are distant relatives. Although the felsic to locally mafic Highlandcroft and Oliverian plutons suggest a continental arc setting, the tholeiitic basalts of the Quimby sequence (the upper Ammonoosuc and Partridge of Schumacher, 1988; Hollocher, 1993) in Massachusetts might be interpreted to have been mantle-derived magmas that penetrated broken the Grenvillian continental lithosphere.

Owing to the buoyancy of subducted Grenville crust, uplift occurred northwest of the Silurian tectonic hinge (Fig. 1), accompanied by major subsidence to the southeast (Fig. 7D and E). This event was first expressed by erosion that preceded deposition of the Quimby Formation; it was more impressively expressed by deposition of the enormously thick, northwest-derived fanglomerate and debris-flow deposits and associated proximal turbidities of the Lower Silurian Rangeley Formation of the Central Maine trough in western Maine (Moench et al., 1995) and debris flows of both margins of trough in eastern Maine (Ludman et al., 1993, esp. Fig. 7). As discussed by Moench et al. (1999), this event terminated the Taconian orogeny and ushered in a regime of major, pre-Acadian Silurian extension. 
Bourque et al. (2000) stressed the role of tectonic extension that accompanied late Wenlockian to Pridolian sedimentation in the Gaspé belt.

By $420 \mathrm{Ma}$ (Fig. 7E), rapid subduction of old, cold oceanic crust resulted in rollback of both subduction zones that in turn resulted in closure of the "Fredericton Sea". On the southeast side, rifted arc volcanics of the coastal volcanic belt were erupted on composite AV. On the northwest, however, the newly accreted margin of Laurentia was greatly extended by rollback of opposed subduction boundaries within the "Fredericton sea", unhindered by continental crust. In fact, continental crust, such as the Gander basement-Avalon connection of van Staal's model (1994, Fig. 8D), would severely interfere with rollback and would, therefore, prohibit significant extension.

As proposed elsewhere (Moench, 1996b; Moench et al., 1999), the Connecticut Valley trough, the Bronson Hill and other anticlinoria of axial New England, and the Central Maine trough became a graben-horst-graben structural complex that ruptured the Taconian margin. While the troughs deepened and widened through Silurian time, Ordovician and older rocks of the anticlinoria were sliced from the margin and became horsts that migrated southeastward to positions that were probably well southeast of their present distribution. These migrations were accompanied by the emplacement of strongly bimodal volcanics, intrusives, and diapiric serpentinites represented, for example, by the magmatic axis of the Second Lake rift (Fig. 2, SLRA) and associated dike swarms and sheeted dike bodies (Figs. 2, 3, 4C, DS). The partly mantle-derived magmas of the rift axis penetrated the Grenville basement of Laurentia, which was thinned and ruptured below the Connecticut Valley trough (see Stewart et al., 1993, Interpretive Cross Section).

By earliest Devonian time, perhaps about $415 \mathrm{Ma}$, the opposed subduction zones had occluded along the proposed New Brunswick line and were buried by deposits of the Fredericton trough, which was all that remained of the "Fredericton Sea". Pending further study, the opposed structural vergence shown by the Brunswick and Penobscot Bay subduction complexes, and an evolution toward strongly bimodal magmatism along the coastal belt (van Wagoner et al., 1988; Gates and Moench, 1981; Seaman et al., 1995; Ludman and Idleman, 1998) seem closely comparable to the consequences of divergent double subduction in the Lachlan fold belt of southeast Australia (Soesoo et al., 1997).

Avalon and adjacent tracts (AV) were now poised for the Acadian collision against all of the previously accreted peri-Avalonian and peri-Laurentian terranes. The rigidity of Avalon, in contrast to the weakness of the extended and necked Laurentian margin to the north, may account for the lack of significant Acadian deformation and metamorphism of Avalon, in contrast to the well known results of the Acadian orogeny and later faulting and plutonism farther northwest.

Alleghanian tectonism is expressed by emplacement of Late Paleozoic Sebago batholith in southernmost Maine (Aleinikoff in Moench et al., 1995, sites C-1, C-2), and, in Connecticut and eastern Massachusetts, by metamorphism and northwestward thrusting of Avalon under the Putnam-Nashoba belt to exposure in the Willimantic dome and possibly in the Pelham dome (Wintsch et al., 1993). How these events might relate to the final Laurentia-Gondwana collision is another story.

\section{Acknowledgements}

To a large extent, this paper is an outgrowth of our long associations with Gary M. Boone, Wallace A. Bothner, Eugene L. Boudette, John B. Lyons (deceased), and James B. Thompson, Jr. The recent passing of John Lyons is an enormous loss to the science of New England geology and we greatly miss his astute and constructive guidance, humaneness, and quiet but penetrating sense of humor. He was a mentor, colleague, and friend. But we celebrate the life that he led. Moench greatly appreciates advice given by Reuben J. Ross, Jr. concerning the Ordovician System; he is also much indebted to Wallace A. Bothner and Allan Ludman for their guidance through the complexities of coastal New England. We also benefitted from discussions with John F. Slack about VMS settings, petrogenesis of the coastal volcanics, and comments that he made on an early version of the manuscript. An earlier version of this paper was reviewed by John B. Lyons, six months before he died, and Robert Ayuso for the US Geological Survey, and by Paul Karabinos, Robert P. Wintsch, and Robert Jacobi for the Geological Society of America. None of these people necessarily agrees with the contents of this paper, and errors and misstatements of facts contained herein are ours only.

\section{Appendix A. Supporting data for $\mathrm{U}-\mathrm{Pb}$ ages listed in Table 1}

\section{A.1. Analytical methods}

Zircon, monazite, and sphene were extracted from approximately $25-50 \mathrm{~kg}$ of rock collected from outcrop exposures. Standard mineral separation procedures were used, including crushing, pulverizing, Wilfley table, magnetic, and heavy liquid separation. Most samples were collected during 1981-1984 when the typical size of an analyzed zircon fraction in our laboratory was about 2-20 mg. Nearly all data presented in this paper were obtained from large fractions; our more recent analyses 
used small $(<0.3 \mathrm{mg})$, hand-picked splits. Larger fractions of zircon were prepared by sieving, magnetic separation of the least magnetic grains, and removal of grains whose appearances (i.e. dark color, deformed morphology, broken fragments) suggested that their isotopic systematics might be disturbed. Despite this relatively "primitive" technology, reliable linear arrays with reasonable upper intercept ages were obtained.

All fractions of zircon were dissolved in concentrated $\mathrm{HF}$ and $\mathrm{HNO}_{3}$ in Teflon capsules inside stainless steel casings at about $205{ }^{\circ} \mathrm{C}$. Monazite and sphene were dissolved in Teflon screw-top containers on a hot plate at about $150{ }^{\circ} \mathrm{C}$. Dissolution normally took about 3-5 days, after which the solutions were spiked with ${ }^{235} \mathrm{U}$ and aliquoted for lead composition and lead concentration and spiked with ${ }^{208} \mathrm{~Pb}$. Uranium and lead were extracted by ion-exchange chemistry (modified from Krogh, 1973). Lead and uranium isotopic ratios were measured, using $\mathrm{H}_{3} \mathrm{PO}_{4}$-silica gel/single Re filament and $\mathrm{HNO}_{3} /$ triple filament, respectively, on an automated VG MicroMass 54E mass spectrometer with a single Faraday cup and Daly multiplier. More recent analyses were made on hand-picked fractions composed of a few grains (about 0.015-0.100 mg). These fractions were spiked with a mixed ${ }^{205} \mathrm{~Pb}-{ }^{233} \mathrm{U}-{ }^{236} \mathrm{U}$ tracer. Uncertainties in isotopic ratios listed in Table 1 were calculated using the PBDAT program of Ludwig (1991a). Data lacking uncertainties were collected early in the study; using these data, we assumed $1 \%$ error in $\mathrm{Pb} / \mathrm{U}$ and $0.1 \%$ error for ${ }^{207} \mathrm{~Pb} /{ }^{206} \mathrm{~Pb}$ for regression calculations. In the large samples, blank lead of about 1 nanogram had little influence on the age calculations (see high ${ }^{206} \mathrm{~Pb} /{ }^{204} \mathrm{~Pb}$ in most samples); smaller samples had a blank lead of about 10-20 pg. All concordia intercept ages were calculated using the ISOPLOT program of Ludwig (1991b); all errors are cited as 2-sigma uncertainties.

\section{A.2. Results}

$\mathrm{U}-\mathrm{Pb}$ analyses of zircon (plus some monazite and sphene) from thirteen samples of plutonic rocks and two samples of metavolcanic rocks are discussed in order of decreasing age. The data are given in Table 3 and are illustrated in Figs. 8-11. In all cases, the age of a sample is the upper intercept as determined by a best-fit regression through some or all of the data on a concordia plot. In only two samples did we encounter any fractions older than the interpreted age of the rock. However, many samples contain fractions that plot to the left of the discordia, suggesting presence of younger overgrowths on some of the zircons.

A. Joslin Turn pluton (sample M-5-88; Fig. 8). Massive, medium-grained altered tonalite collected from a cascade in Halls Brook, about $1 \mathrm{~km}$ upstream from Moore Reservoir (Fig. 4C; Moench et al., 1995, site
O-13). Four fractions of zircon were analyzed, three of which yielded concordant $\mathrm{U}-\mathrm{Pb}$ data. Because of the minimal spread in the data with nearly identical ${ }^{207} \mathrm{~Pb} /$ ${ }^{206} \mathrm{~Pb}$ ages, the regression was forced through a lower intercept of $0 \pm 50 \mathrm{Ma}(\mathrm{MSWD}=0.19)$. The upper intercept age of $469 \pm 2 \mathrm{Ma}$ is interpreted as the age of emplacement of the tonalite, probably synchronous with early eruptions of the Ammonoosuc Volcanics, as already discussed.

B. Cambridge Black pluton (sample NH/Mi 1-84; Fig. 8). Weakly foliated, medium-grained, pink alkalifeldspar biotite granite collected from a large outcrop on the lower south side of Cambridge Black Mountain (Fig. 4B; Moench et al., 1995, site O-9). Zircons were analyzed at two different times. The first group of analyses, from very large fractions $(2.3-9.4 \mathrm{mg})$ yielded discordant and scattered data (Table 3). Additional, smaller fractions of hand-picked zircons $(0.014-0.027$ $\mathrm{mg}$ ) yielded less discordant, colinear isotopic data. All zircons from this sample have very high uranium contents (about 3000-5340 ppm). Regression of the three small fractions, plus data from two discordant fractions, has intercept ages of $468 \pm 3$ and $207 \pm 12 \mathrm{Ma}$ $(\mathrm{MSWD}=0.17)$. The lower intercept age may reflect $\mathrm{Pb}$-loss due to a thermal perturbation related to emplacement of the Mesozoic White Mountain batholith.

C. Tonalite of Chickwolnepy intrusions (sample NH/ Mi 2-84; Fig. 8). Foliated, gray, quartz-porphritic hornblende-biotite tonalite collected from a ridge on the west side of Cambridge Black Mountain (Fig. 4B; Moench et al., 1995, site O-7). Data from four of five fractions of zircon form a colinear array with an upper intercept age of about $467 \pm 4 \mathrm{Ma}(\mathrm{MSWD}=0.038)$ and a lower intercept of near zero, indicating only modern $\mathrm{Pb}$ loss. Isotopic data from the fifth fraction, composed of coarse zircons of the $(+150)$ size fraction, plots slightly to the left of the discordia, suggesting either lead loss or overgrowth formation sometime in the past. It was excluded from the age calculation because it substantially increased the MSWD of the best-fit regression.

D. Scrag granite of Jefferson batholith (sample NH/F 1-85; Fig. 8). Weakly foliated, pink, coarse-grained biotite granite collected from a large outcrop on the southwest side of Scrag Hill, northeast of Franconia, NH (Moench et al., 1995; site O-8). Six fractions of zircons yielded colinear isotopic data with intercept ages of $456 \pm 3$ and $170 \pm 26 \mathrm{Ma}$. Uranium content increases with decreasing grain size and is directly correlative with degree of discordance. Monazite from this sample is concordant at $254 \mathrm{Ma}$.

E. Granodiorite to quartz diorite of Jefferson batholith (sample NH/Pcy 1-81; Fig. 9). Foliated, gray, medium-grained biotite trondhjemite collected from an outcrop on the south side of NH Route 110, about $8 \mathrm{~km}$ northwest of Berlin, NH (Moench et al., 1995, site 
Table 3

Uranium-lead geochronology of zircon, monazite and sphene from igneous rocks in northern New Hampshire and Maine

\begin{tabular}{|c|c|c|c|c|c|c|c|c|c|c|c|c|}
\hline \multirow[t]{2}{*}{ Fraction $^{\mathrm{a}}$} & \multirow[t]{2}{*}{$\begin{array}{l}\text { Wt. } \\
\text { (mg.) }\end{array}$} & \multicolumn{2}{|c|}{$\begin{array}{l}\text { Concentration } \\
(\mathrm{ppm})\end{array}$} & \multicolumn{3}{|c|}{$\mathrm{Pb}$ composition ${ }^{\mathrm{b}}$} & \multicolumn{2}{|c|}{ 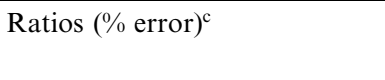 } & \multicolumn{4}{|l|}{ Ages $(\mathrm{Ma})^{\mathrm{d}}$} \\
\hline & & $\mathrm{U}$ & $\mathrm{Pb}$ & ${ }^{206} \mathrm{~Pb} /{ }^{204} \mathrm{~Pb}$ & $\begin{array}{l}{ }^{206} \mathrm{~Pb} / \\
{ }^{207} \mathrm{~Pb}\end{array}$ & $\begin{array}{l}{ }^{206} \mathrm{~Pb} / \\
{ }^{208} \mathrm{~Pb}\end{array}$ & ${ }^{206} \mathrm{~Pb} /{ }^{238} \mathrm{U}$ & ${ }^{207} \mathrm{~Pb} /{ }^{235} \mathrm{U}$ & ${ }^{207} \mathrm{~Pb} /{ }^{206} \mathrm{~Pb}$ & ${ }^{206} \mathrm{~Pb} /{ }^{238} \mathrm{U}$ & $\begin{array}{l}{ }^{207} \mathrm{~Pb} / \\
{ }^{235} \mathrm{U}\end{array}$ & $\begin{array}{l}{ }^{207} \mathrm{~Pb} / \\
{ }^{206} \mathrm{~Pb}\end{array}$ \\
\hline \multicolumn{13}{|c|}{ Plutonic rocks } \\
\hline \multicolumn{13}{|c|}{ A. $M-5-88$ (Joslin Turn pluton, 44_21'50" $N, 71 \_50^{\prime} 50^{\prime \prime} W$ ) } \\
\hline$(-100+150) \mathrm{EA}$ & 0.130 & 239.1 & 20.87 & 1863.9 & 15.557 & 3.7729 & $0.0755(0.20)$ & $0.5878(0.35)$ & $0.0565(0.29)$ & 469 & 469 & 471 \\
\hline$(-100+150)$ EA & 0.084 & 235.6 & 20.16 & 7918.4 & 17.159 & 3.8791 & $0.0754(0.17)$ & $0.5864(0.21)$ & $0.0564(0.11)$ & 468 & 469 & 470 \\
\hline$(-100+150) \mathrm{EA}$ & 0.093 & 217.5 & 18.16 & 5357.1 & 16.904 & 4.1776 & $0.0744(0.60)$ & $0.5791(0.66)$ & $0.0564(0.26)$ & 463 & 464 & 470 \\
\hline$(-100+150) \mathrm{EA}$ & 0.110 & 286.2 & 24.32 & 7785.8 & 17.155 & 4.0658 & $0.0755(0.20)$ & $0.5872(0.22)$ & $0.0564(0.10)$ & 469 & 469 & 469 \\
\hline \multicolumn{13}{|c|}{ 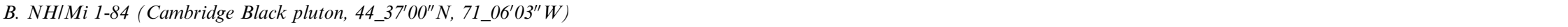 } \\
\hline$(+150) \mathrm{NM}$ & 2.33 & 3016 & 185.4 & 3634.4 & 16.928 & 11.981 & $0.0623(0.51)$ & $0.4725(0.52)$ & $0.0551(0.07)$ & 389 & 393 & 414 \\
\hline$(-150+200) \mathrm{NM}$ & 9.42 & 3775 & 212.5 & 4585.8 & 17.220 & 12.211 & $0.0572(0.48)$ & $0.4327(0.52)$ & $0.0549(0.19)$ & 358 & 365 & 408 \\
\hline$(-150+200) \mathrm{NM}$ & 4.83 & 3211 & 190.3 & 4093.0 & 17.086 & 13.258 & $0.0605(0.45)$ & $0.4584(0.45)$ & $0.0550(0.04)$ & 379 & 383 & 411 \\
\hline$(-150+200) \mathrm{EA}$ & 0.014 & 5340 & 361.3 & 9634.3 & 17.453 & 8.1812 & $0.0666(0.13)$ & $0.5120(0.14)$ & $0.0558(0.04)$ & 415 & 420 & 444 \\
\hline$(-150+200) \mathrm{EA}$ & 0.027 & 5342.1 & 377.4 & 15549 & 17.572 & 7.5385 & $0.0689(0.34)$ & $0.5321(0.35)$ & $0.0560(0.06)$ & 430 & 433 & 451 \\
\hline$(-150+200) \mathrm{EA}$ & 0.014 & 5041.6 & 354.4 & 8018.6 & 17.32 & 7.4911 & $0.0684(0.17)$ & $0.5277(0.17)$ & $0.0559(0.05)$ & 427 & 430 & 449 \\
\hline$(-200+250) \mathrm{NM}$ & 3.68 & 3075 & 197.0 & 4668.2 & 17.110 & 10.949 & $0.0645(0.45)$ & $0.4922(0.45)$ & $0.0553(0.08)$ & 403 & 406 & 425 \\
\hline$(-250+325) \mathrm{NM}$ & 4.40 & 3218 & 208.3 & 4562.6 & 17.109 & 10.289 & $0.0649(0.43)$ & $0.4941(0.44)$ & $0.0553(0.11)$ & 405 & 408 & 423 \\
\hline$(-325) \mathrm{NM}$ & 5.70 & 3689 & 219.3 & 5225.7 & 17.250 & 10.576 & $0.0597(0.46)$ & $0.4548(0.47)$ & $0.0552(0.11)$ & 374 & 381 & 419 \\
\hline \multicolumn{13}{|c|}{ C. NHIMi 2-84 (tonalite of Chickwolnepy intrusions, 44_37'44" $N, 71 \_07^{\prime} 35^{\prime \prime} \mathrm{W}$ ) } \\
\hline$(+150) \mathrm{DA}$ & 0.64 & 733.4 & 56.25 & 12478 & 17.419 & 5.5694 & $0.0719(0.47)$ & $0.5575(0.47)$ & $0.0562(0.07)$ & 448 & 450 & 462 \\
\hline$(+150) \mathrm{NM}$ & 7.58 & 790.8 & 61.11 & 5631.5 & 16.973 & 5.4565 & $0.0721(0.75)$ & $0.5597(0.76)$ & $0.0563(0.11)$ & 449 & 451 & 465 \\
\hline$(-150+200)$ & 0.054 & 451.1 & 35.05 & 7417.7 & 17.147 & 6.2820 & $0.0740(0.23)$ & $0.5748(0.25)$ & $0.0564(0.10)$ & 460 & 461 & 466 \\
\hline$(-150+200) \mathrm{NM}$ & 6.27 & 760.7 & 58.58 & 7717.8 & 17.174 & 5.8624 & $0.0727(0.45)$ & $0.5644(0.47)$ & $0.0563(0.15)$ & 452 & 454 & 466 \\
\hline$(-200+250) \mathrm{NM}$ & 3.60 & 1139 & 87.84 & 7157.1 & 17.132 & 5.1567 & $0.0714(0.44)$ & $0.5543(0.46)$ & $0.0563(0.14)$ & 444 & 448 & 465 \\
\hline \multicolumn{13}{|c|}{ D. NHIF 1-85 (Scrag granite of Jefferson batholith, 44_14'40" $N, 71 \_44^{\prime} 03^{\prime \prime} W$ ) } \\
\hline$(+150)$ NMDANM & 5.31 & 655.1 & 51.73 & 7522.6 & 17.291 & 3.9655 & $0.0699(0.90)$ & $0.5384(0.90)$ & $0.0559(0.07)$ & 435 & 437 & 448 \\
\hline$(-150+200) \mathrm{D}$ & 6.67 & 700.8 & 54.03 & 22799 & 17.707 & 4.1671 & $0.0690(0.45)$ & $0.5316(0.46)$ & $0.0559(0.06)$ & 430 & 433 & 447 \\
\hline$(-200+250) \mathrm{D}$ & 5.80 & 849.7 & 65.72 & 3653.1 & 16.715 & 4.0870 & $0.0685(0.81)$ & $0.5275(0.82)$ & $0.0558(0.09)$ & 427 & 430 & 446 \\
\hline$(-325) \mathrm{D}$ & 8.01 & 852.1 & 64.84 & 28198 & 17.750 & 4.1542 & $0.0681(0.46)$ & $0.5239(0.61)$ & $0.0558(0.38)$ & 425 & 428 & 445 \\
\hline$(-400) \mathrm{NM}$ & 6.34 & 931.0 & 70.06 & 31237 & 17.778 & 4.1085 & $0.0672(0.52)$ & $0.5168(0.53)$ & $0.0558(0.12)$ & 419 & 423 & 442 \\
\hline$(-400) \mathrm{M}$ & 8.40 & 2151 & 139.3 & 9689.2 & 17.559 & 7.0827 & $0.0627(1.3)$ & $0.4793(1.3)$ & $0.0554(0.06)$ & 392 & 398 & 430 \\
\hline Monazite & 0.0151 & 6550 & 1014 & 526.86 & 12.638 & 1.5943 & $0.0402(0.24)$ & $0.2840(0.25)$ & $0.0513(0.07)$ & 254 & 254 & 254 \\
\hline \multicolumn{13}{|c|}{ E. NH/Pcy 1-81 (granodiorite-quartz diorite of Jefferson batholith, 44_31'21" N, 71_15'12" W) } \\
\hline$(+100) \mathrm{EA}$ & 0.024 & 330.4 & 24.64 & 2254.4 & 16.034 & 6.0025 & $0.0699(0.30)$ & $0.5390(0.42)$ & $0.05590(0.28)$ & 436 & 438 & 448 \\
\hline$(+150) \mathrm{EA}$ & 0.029 & 484.0 & 34.69 & 1064.9 & 14.423 & 5.9083 & $0.0661(0.41)$ & $0.5069(0.48)$ & $0.0556(0.24)$ & 412 & 416 & 438 \\
\hline$(+150)$ EA & 0.017 & 212.5 & 16.45 & 613.82 & 12.530 & 5.0114 & $0.0682(0.29)$ & $0.5268(0.61)$ & $0.0561(0.51)$ & 425 & 430 & 454 \\
\hline$(+150)$ EA & 0.023 & 401.5 & 29.94 & 3819.0 & 16.468 & 6.6638 & $0.0712(0.48)$ & $0.5590(0.54)$ & $0.0569(0.23)$ & 444 & 451 & 488 \\
\hline$(+150)$ EA & 0.020 & 458.3 & 43.34 & 876.54 & 12.483 & 5.5638 & $0.0854(0.43)$ & $0.7489(0.49)$ & $0.0636(0.21)$ & 528 & 568 & 729 \\
\hline$(+150) \mathrm{NM}$ & 16.75 & 680.8 & 44.17 & 9950.0 & 17.559 & 8.1031 & 0.0638 & 0.4884 & 0.0555 & 399 & 404 & 434 \\
\hline$(+150) \mathrm{M}$ & 11.10 & 2498 & 158.5 & 4208.1 & 16.943 & 11.242 & 0.0640 & 0.4902 & 0.0556 & 400 & 405 & 434 \\
\hline$(-150+200) \mathrm{NMA}$ & 10.32 & 676.6 & 46.71 & 6375.6 & 17.231 & 7.2667 & $0.0669(0.73)$ & $0.5140(0.74)$ & $0.0557(0.07)$ & 418 & 421 & 442 \\
\hline$(-325) \mathrm{NM}$ & 15.28 & 914.7 & 57.43 & 232860 & 18.000 & 8.2481 & 0.0620 & 0.4746 & 0.0555 & 388 & 394 & 432 \\
\hline Monazite & 0.018 & 4570 & 817.0 & 962.2 & 14.859 & 0.29913 & $0.0459(0.19)$ & $0.3298(0.21)$ & $0.0521(0.09)$ & 290 & 289 & 289 \\
\hline
\end{tabular}




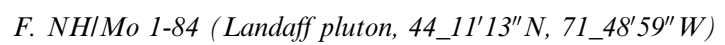
$\begin{array}{llll}(-150+200) \mathrm{NM} & 3.55 & 349.7 & 25.28\end{array}$

$\begin{array}{lll}3.07 & 924.3 & 66.64\end{array}$

$\begin{array}{lll}0.013 & 323.3 & 32.85\end{array}$

$(-150+200)$ EA

$\begin{array}{llll}0.021 & 310.4 & 23.705 & 1246.2 \\ 0.040 & 215.4 & 17.05 & 1253.9\end{array}$

$(-200+2500 \mathrm{NM}$

$(-250+325) \mathrm{NM}$

$(-325+400) \mathrm{D}$

$\begin{array}{lll}5.32 & 497.7 & 36.42\end{array}$

$\begin{array}{llll}3.61 & 445.2 & 32.04 & 19278\end{array}$

$(-400) \mathrm{NM}$

$\begin{array}{lll}3.11 & 430.35 & 31.85\end{array}$

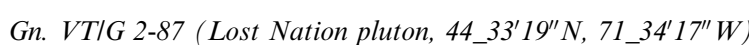

$(-100+150) \mathrm{DA} \quad 8.74 \quad 644.8 \quad 50.21$

$N M$

$(-100+150) \mathrm{DE}$

$0.43 \quad 1242$

96.41

Dust

$(-150+200) \mathrm{DE}$

$1.25 \quad 880.7$

64.61

910.42

13.927

Dust

$(-325+400) \mathrm{D}$

(-400)D

Sphene NM

$7.69 \quad 772.8$

Sphene M

$\begin{array}{lll}7.69 & 772.8 & 59.84 \\ 15.00 & 734.4 & 58.63\end{array}$

695.8

13.306

3.9826

$0.0624(0.57)$

3194.5

16.582

14.999

Gs. NH/Wh

$\begin{array}{ccc}6.35 & 734.4 & 58.63 \\ 11.61 & 100.8 & 18.55 \\ & 72.52 & 18.26\end{array}$

117.3
69.56

5.580

3.5828

3.2650

0.7134

$0.0667(0.58)$

$0.0666(0.46)$

$0.0699(0.69)$

$0.0693(0.62)$

$0.5115(0.55)$

$0.5334(0.97)$

$0.5289(1.5)$

9.2800

3.3281

$0.0711(0.62)$

$0.5484(0.6$

(zircon $U-P b$ data in Lyons et al., 1986)

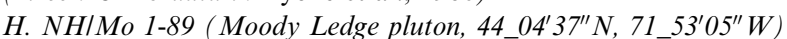

$\begin{array}{ccccc}(-100+200) \mathrm{EA} & 0.039 & 806.7 & 78.11 & 2222\end{array}$

$(-100+200) \mathrm{EA}$

$\begin{array}{lllr}0.020 & 743.6 & 72.72 & 3006.4\end{array}$

$(-100+200) \mathrm{EA}$

$60.38 \quad 11888$

I. $M$-380-81 (Tunnel Brook pluton, 44_05'29"N, 71_49'37" W)

$\begin{array}{cccc}(-100+150) \mathrm{NM} & 13.77 & 1096 & 76.67\end{array}$

$(-100+150) \mathrm{DC}$

5006.2

$(-200+250) \mathrm{DC}$

$\begin{array}{lll}5.07 & 224.7 & 15.18\end{array}$

$(-250+325) \mathrm{NM}$

$(-325) \mathrm{NM}$

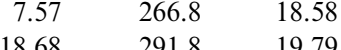

20357

3610.0
53432.7

J. NH/MC 1-85 (Fairlee pluton, $43^{\circ} 54^{\prime} 45^{\prime \prime} N, 72^{\circ} 08^{\prime} 08^{\prime \prime} W$ )

$\begin{array}{lrrr}(+150) \text { NMEC } & 2.88 & 435.2 & 27.11\end{array}$

$\begin{array}{llll}(-150+200) \text { NMEC } & 8.78 & 473.5 & 28.79\end{array}$

$\begin{array}{llll}++150) \text { NMEDust } & 2.19 & 457.9 & 30.40\end{array}$

Monazite

$\begin{array}{lll}3.60 & 1006 \quad 781.2\end{array}$

$(3.943 \% \mathrm{Th})$

K. NH/Mln 1-81 (Umbagog pluton, 44_42'06", 71_02'30")

$\begin{array}{lccc}(+150) \mathrm{CA} & 0.060 & 660.4 & 45.02 \\ (+150) \mathrm{NM} & 17.76 & 1110 & 83.50\end{array}$

3586.2

11865

710.12

17.687

16.398

17.523

1.8338

1.8726

$0.0701(0.20)$

$0.0707(0.34)$

$0.0693(0.31)$

$0.5471(0.42)$

$0.5338(0.32)$

$0.0717(0.25)$

$0.5530(0.26)$

$0.0559(0.10)$

$0.0561(0.24)$

$0.0558(0.09)$

$0.0559(0.06)$

17.112

15.017

6.0172

0.0661

17.770

5.8527

$0.0686(0.44)$
$0.0664(0.44)$

0.5062

$0.5257(0.45)$

0.0555

$0.0556(0.10)$

$0.0556(0.06)$

0.0557

$\begin{array}{lll}17.153 & 7.7709 & 0.0662\end{array}$

0.5071

0.0556

$0.4874(0.66)$

$0.4829(0.48)$

$0.0550(0.29)$

$0.0550(0.13)$

$\begin{array}{lll}17.795 & 19.252 & 0.0637(0.46)\end{array}$

$0.0617(0.56)$

$0.4680(0.57)$

$0.0550(0.11)$

$0.0547(0.16)$

$\begin{array}{lll}16.2546 & 0.08114 & 0.0664(0.33)\end{array}$

$0.5002(0.37)$

7680.6

2981.3

17.841

3.9776

$0.0604(0.30)$

0.0575

$0.4511(0.32)$

0.4299

$0.0541(0.11)$

0.0543

360

60

363

383 
Table 3 (continued)

\begin{tabular}{|c|c|c|c|c|c|c|c|c|c|c|c|c|}
\hline \multirow[t]{2}{*}{ Fraction $^{\mathrm{a}}$} & \multirow[t]{2}{*}{$\begin{array}{l}\text { Wt. } \\
\text { (mg.) }\end{array}$} & \multicolumn{2}{|c|}{$\begin{array}{l}\text { Concentration } \\
(\mathrm{ppm})\end{array}$} & \multicolumn{3}{|c|}{$\mathrm{Pb}$ composition ${ }^{\mathrm{b}}$} & \multicolumn{2}{|c|}{ Ratios (\% error) ${ }^{\mathrm{c}}$} & \multicolumn{4}{|l|}{ Ages $(\mathrm{Ma})^{\mathrm{d}}$} \\
\hline & & $\overline{\mathrm{U}}$ & $\mathrm{Pb}$ & ${ }^{206} \mathrm{~Pb} / 204 \mathrm{~Pb}$ & $\begin{array}{l}{ }^{206} \mathrm{~Pb} / \\
{ }^{207} \mathrm{~Pb}\end{array}$ & $\begin{array}{l}{ }^{206} \mathrm{~Pb} / \\
{ }^{208} \mathrm{~Pb}\end{array}$ & ${ }^{206} \mathrm{~Pb} /{ }^{238} \mathrm{U}$ & ${ }^{207} \mathrm{~Pb} /{ }^{235} \mathrm{U}$ & ${ }^{207} \mathrm{~Pb} /{ }^{206} \mathrm{~Pb}$ & ${ }^{206} \mathrm{~Pb} /{ }^{238} \mathrm{U}$ & $\begin{array}{l}{ }^{207} \mathrm{~Pb} / \\
{ }^{235} \mathrm{U}\end{array}$ & $\begin{array}{l}{ }^{207} \mathrm{~Pb} / \\
{ }^{206} \mathrm{~Pb}\end{array}$ \\
\hline$(+150) \mathrm{DA}$ & 4.70 & 979.9 & 74.28 & 2506.5 & 16.608 & 2.0118 & $0.0561(0.45)$ & $0.4203(0.46)$ & $0.0548(0.09)$ & 352 & 356 & 387 \\
\hline$(-200+250) \mathrm{D}$ & 6.16 & 1013 & 67.73 & 9922.7 & 17.917 & 2.9430 & $0.0555(0.46)$ & $0.4161(0.46)$ & $0.0543(0.08)$ & 348 & 353 & 385 \\
\hline$(-325) \mathrm{NM}$ & 19.05 & 1257 & 84.86 & 20480 & 18.188 & 3.5131 & 0.0585 & 0.4375 & 0.0543 & 366 & 368 & 382 \\
\hline \multicolumn{13}{|c|}{ 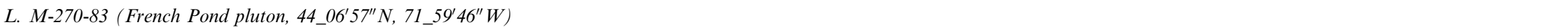 } \\
\hline (+150)DANM & 6.65 & 911.6 & 52.40 & 8062.7 & 17.963 & 4.9035 & $0.0529(0.45)$ & $0.3928(0.45)$ & $0.0539(0.06)$ & 332 & 336 & 365 \\
\hline$(-150+200) \mathrm{D}$ & 11.61 & 1013 & 55.40 & 8946.1 & 18.028 & 5.4870 & $0.0513(0.46)$ & $0.3805(0.48)$ & $0.0538(0.13)$ & 322 & 327 & 364 \\
\hline$(-200+250) \mathrm{D}$ & 17.96 & 1049 & 57.45 & 11285 & 18.153 & 5.1836 & $0.0509(0.83)$ & $0.3777(0.84)$ & $0.0538(0.07)$ & 320 & 325 & 362 \\
\hline$(-325) \mathrm{D}$ & 14.77 & 1126 & 61.09 & 6148.9 & 17.778 & 4.8243 & $0.0498(0.45)$ & $0.3696(0.46)$ & $0.0539(0.09)$ & 313 & 319 & 366 \\
\hline Sphene & 0.109 & 172.65 & 22.534 & 131.25 & 6.0659 & 0.87779 & $0.0563(0.21)$ & $0.4154(0.41)$ & $0.0535(0.33)$ & 353 & 353 & 351 \\
\hline \multicolumn{13}{|c|}{ Metavolcanic rocks } \\
\hline \multicolumn{13}{|c|}{ 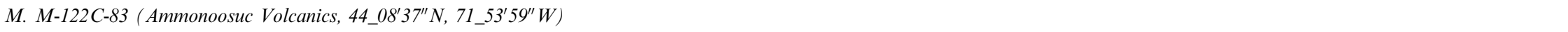 } \\
\hline$(-200+325) \mathrm{EC} 1$ & 0.020 & $28 \overline{6} .5$ & $24 . \overline{58}$ & 725.55 & 13.109 & 3.0330 & $0.0690(0.73)$ & $0.5348(0.78)$ & $0.0562(0.26)$ & 430 & 435 & 460 \\
\hline$(-200+325) \mathrm{EC} 2$ & 0.019 & 262.9 & 27.99 & 342.92 & 9.5407 & 2.8327 & $0.0802(0.75)$ & $0.6923(0.85)$ & $0.0626(0.38)$ & 497 & 534 & 696 \\
\hline$(+200) \mathrm{NM}$ & 1.75 & 320.1 & 27.01 & 1655.4 & 15.186 & 3.6390 & $0.0723(0.46)$ & $0.5684(0.57)$ & $0.0570(0.31)$ & 450 & 457 & 493 \\
\hline$(-200+250) \mathrm{NM}$ & 4.87 & 560.5 & 41.51 & 668.57 & 12.838 & 3.1114 & $0.0597(0.46)$ & $0.4620(0.48)$ & $0.0561(0.13)$ & 374 & 386 & 456 \\
\hline$(-250+325) \mathrm{NM}$ & 12.58 & 457.0 & 35.64 & 1184.8 & 14.613 & 3.2065 & $0.0646(0.46)$ & $0.4997(0.58)$ & $0.0561(0.32)$ & 403 & 412 & 458 \\
\hline$(-325+400) \mathrm{NM}$ & 11.48 & 348.6 & 28.64 & 1287.4 & 14.731 & 3.1658 & $0.0680(0.46)$ & $0.5300(0.50)$ & $0.0566(0.18)$ & 422 & 432 & 475 \\
\hline$(-400)$ & 8.37 & 319.3 & 27.13 & 2261.7 & 15.658 & 3.1636 & $0.0709(0.47)$ & $0.5616(0.67)$ & $0.0574(0.45)$ & 442 & 453 & 508 \\
\hline \multicolumn{13}{|c|}{ 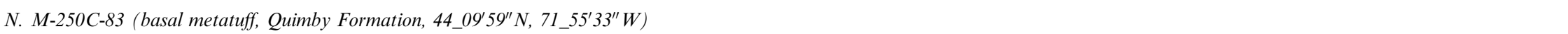 } \\
\hline$(-100) \mathrm{CA}$ & 0.042 & 307.8 & 24.53 & 488.25 & 11.663 & 3.6835 & $0.0656(0.48)$ & $0.5053(0.54)$ & $0.0559(0.26)$ & 410 & 415 & 447 \\
\hline$(-150+200) \mathrm{CA}$ & 0.108 & 214.8 & 22.32 & 173.89 & 7.1606 & 2.5421 & $0.0702(0.14)$ & $0.5402(0.3)$ & $0.0558(0.26)$ & 438 & 439 & 443 \\
\hline$(-150+200) \mathrm{CA}$ & 0.085 & 245.1 & 18.30 & 6686.1 & 17.246 & 5.3839 & $0.0696(0.19)$ & $0.5354(0.23)$ & $0.0558(0.13)$ & 434 & 435 & 445 \\
\hline$(+150) \mathrm{D}$ & 6.20 & 290.0 & 20.44 & 9158.9 & 17.4428 & 5.4571 & 0.0659 & 0.5062 & 0.0557 & 411 & 416 & 442 \\
\hline$(-150+200) \mathrm{D}$ & 13.73 & 320.7 & 22.65 & 2703.7 & 16.3746 & 5.28418 & 0.0652 & 0.5003 & 0.0557 & 407 & 412 & 439 \\
\hline$(-250+325) \mathrm{D}$ & 8.76 & 320.2 & 22.02 & 21196 & 17.768 & 5.7003 & 0.0648 & 0.4969 & 0.0556 & 405 & 410 & 436 \\
\hline$(-325) \mathrm{D}$ & 9.30 & 382.4 & 29.45 & 438.32 & 11.201 & 3.9304 & 0.0637 & 0.4920 & 0.0560 & 398 & 406 & 452 \\
\hline
\end{tabular}

Constants: ${ }^{235} \mathrm{I}=9.8485 \mathrm{E}-10 / \mathrm{yr} ;{ }^{238} \mathrm{I}=1.55125 \mathrm{E}-10 / \mathrm{yr} ;{ }^{238} \mathrm{U} /{ }^{235} \mathrm{U}=137.88$ (Steiger and Jäger, 1977).

${ }^{a}$ Abbreviations: E (elongate), NM (non-magnetic), D (diamagnetic), A (abraded), M (magnetic), C (clear), P (prismatic), R (round), Dust (fine-grained material collected during abrasion in ceramic mill; Aleinikoff et al., 1990).

${ }^{\mathrm{b}} \mathrm{Pb}$ composition ratios corrected from $0.14 \pm 0.05 \% /$ a.m.u. mass fractionation and blank $\mathrm{Pb}(1-0.01 \mathrm{ng})$ of composition 1:18.8:15.7:38.5.

2 sigma errors where given. Otherwise, ${ }^{206} \mathrm{~Pb} /{ }^{238} \mathrm{U}$ and ${ }^{207} \mathrm{~Pb} /{ }^{235} \mathrm{U}$ errors assumed to be $1 \%$ and ${ }^{207} \mathrm{~Pb} /{ }^{206} \mathrm{~Pb}$ errors assumed to be $0.1 \%$. See text for additional explanation.

${ }^{\mathrm{d}}$ Ages corrected for common lead using the appropriate values from Stacey and Kramers (1975). 

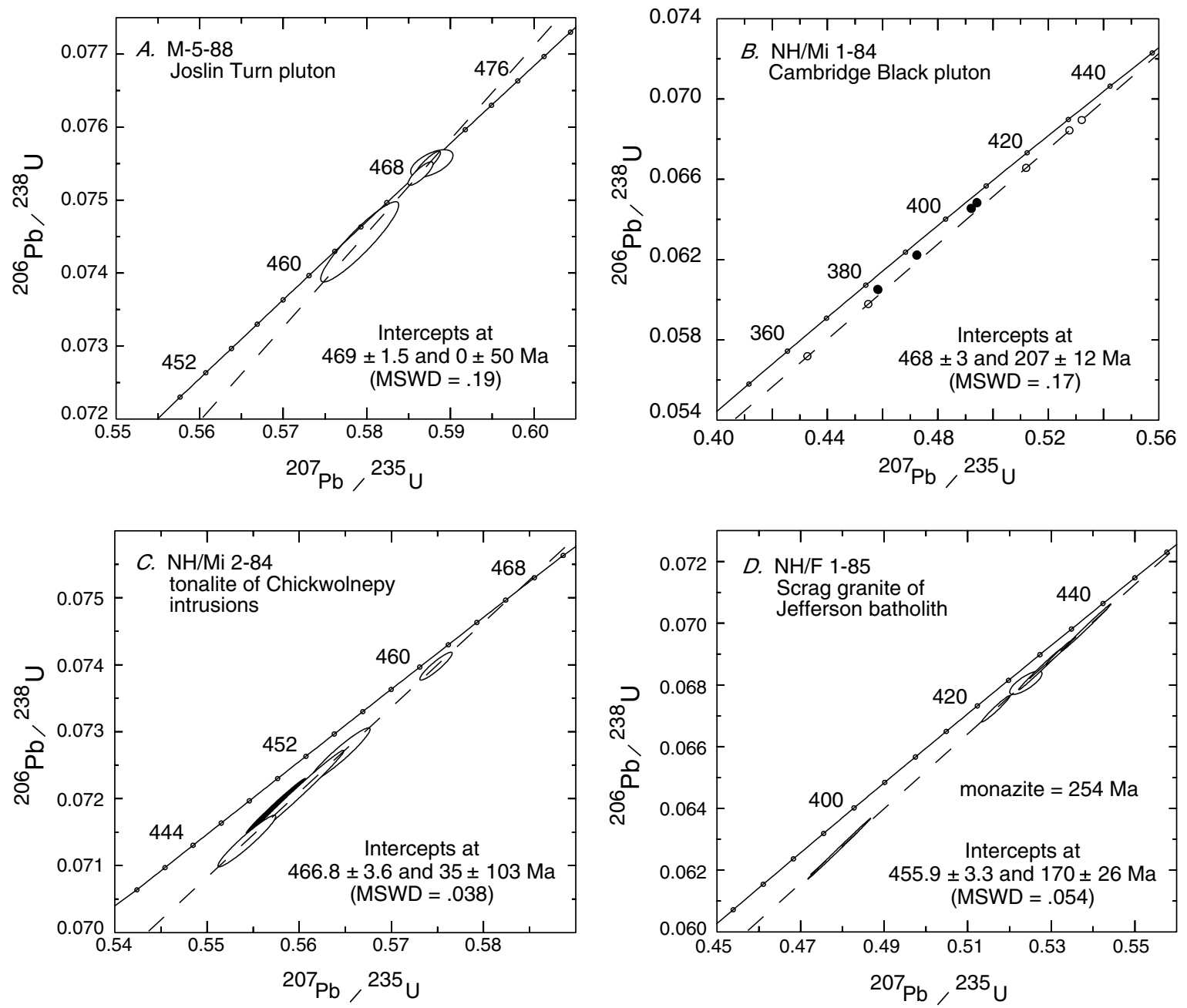

Fig. 8. U-Pb concordia plots for Joslin Turn pluton $(A)$; Cambridge Black pluton $(B)$; youngest tonalite of Chickwolnepy intrusions $(C)$; and Scrag granite (Billings, 1937) of Jefferson batholith $(D)$. Darkened data not incorporated in calculations; see text for explanations.

O-10). Although petrographically and chemically a trondhjemite, mapping indicates that it grades to granodiorite and quartz diorite in a large area in the northern part of the Jefferson batholith (see Moench et al., 1995, unit Oo2-6b); it is probably unrelated to most of the trondhjemite of Leo $(1985,1991$, pp. 22-27) in northern New Hampshire.

Nine zircon fractions (four large and five small) from the trondhjemite were analyzed (Table 3 ). Seven fractions are colinear with intercept ages of $454 \pm 4$ and $149 \pm 30 \mathrm{Ma}$; two other fractions, composed of $(+150)$ grains, have ${ }^{207} \mathrm{~Pb} /{ }^{206} \mathrm{~Pb}$ ages of 488 and $729 \mathrm{Ma}$. These are the only analyzed fractions in the our study that have ${ }^{207} \mathrm{~Pb} /{ }^{206} \mathrm{~Pb}$ ages substantially older than the upper intercept age.

F. Landaff pluton (sample NH/Mo 1-84; Fig. 9). Poorly foliated, leucocratic, fine-grained hastingsite granodiorite collected from a roadside outcrop about 8 km southwest of Franconia, NH (Fig. 4C; Moench et al., 1995, site-O-12). Six large fractions form a colinear array with intercept ages of $455 \pm 15$ and $196 \pm 100 \mathrm{Ma}$ $(\mathrm{MSWD}=0.3)$. The uncertainty in the upper intercept age is large because of the limited spread in the $\mathrm{Pb} / \mathrm{U}$ ages of the six fractions. In an attempt to reduce the uncertainty, we analyzed three additional, much smaller, fractions (Table 1). These fractions also are colinear, but with nearly identical ${ }^{207} \mathrm{~Pb} / 206 \mathrm{~Pb}$ ages of 447,447 , and $449 \mathrm{Ma}$. The regression of these isotopic data (forced through a lower intercept of $0 \pm 50 \mathrm{Ma}$ ) yields an upper intercept age of about $447 \pm 4$ (MSWD $=0.66$ ).

Gn. Lost Nation pluton (sample VT/G 2-87; Fig. 9), northern site. Foliated, gray, medium- to coarse-grained granite collected from a roadcut $7 \mathrm{~km}$ north of Lancaster, NH (Moench et al., 1995, site O-11, northern). Five zircon fractions were analyzed, including two fractions composed of material removed from the rims of grains (see Aleinikoff et al., 1990 for methodology) (Table 3). The isotopic data are colinear with intercept ages of $442 \pm 4$ and $-5 \pm 59 \mathrm{Ma}(\mathrm{MSWD}=0.52)$. Additionally, two fractions of sphene were analyzed; both 

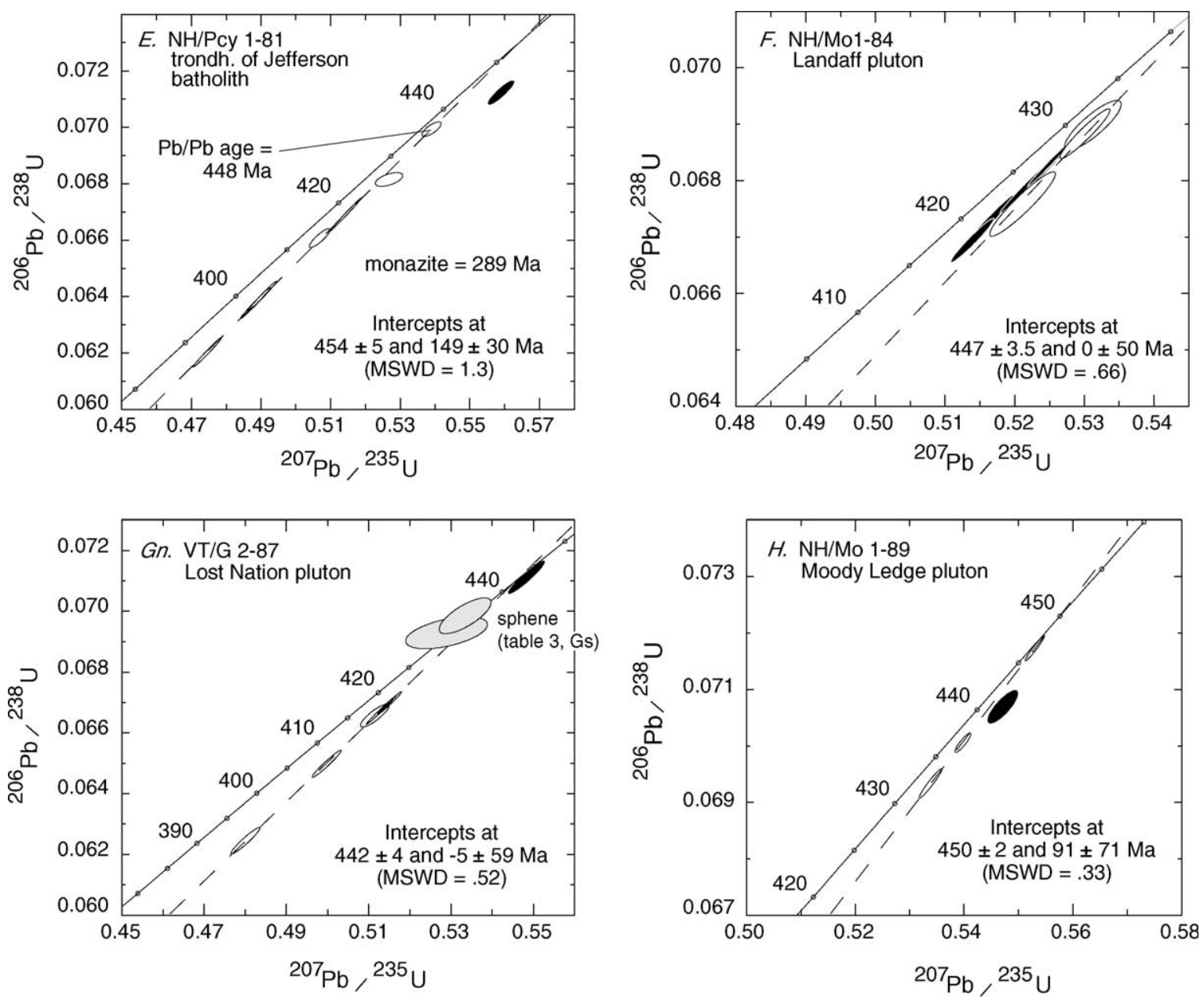

Fig. 9. U-Pb concordia plots for trondhjemite of Jefferson batholith $(E)$; Landaff pluton $(F)$; granite of northern site of Lost Nation pluton $(G n)$, including sphene data (darkened) from northern and southern sites, not incorporated in calculations (see text for explanation); Moody Ledge pluton $(H)$.

have low ${ }^{206} \mathrm{~Pb} / 204 \mathrm{~Pb}$ ratios, and thus the ${ }^{206} \mathrm{~Pb} / 238 \mathrm{U}$ ages (435 and $432 \mathrm{Ma}$ ) are the most reliable indicators of the age. The sphene ages represent the time of closure of the $\mathrm{U}-\mathrm{Pb}$ isotopic system (thought to be about $700{ }^{\circ} \mathrm{C}$, Pidgeon et al., 1996; Corfu, 1996; Zhang and Shärer, 1996), and are indicative of the rate of cooling of the pluton shortly after emplacement.

Gs. Lost Nation pluton (sample NH/Wh 1-79; Table 3), southern site. Weakly foliated quartz diotite collected from a roadcut $5 \mathrm{~km}$ south of Lancaster, $\mathrm{NH}$ (Moench et al., 1995, sites O-11, southern). Previous U-Pb zircon data yielded concordia intercepts at $439 \pm 25$ and $1525 \pm 25 \mathrm{Ma}$ (Lyons et al., 1986). New data from our study are from one fraction of sphene which yielded a concordant age of $443 \pm 3$ Ma (lower shaded ellipse in Fig. 9, Gn).

H. Moody Ledge pluton (sample NH/Mo 1-89; Fig. 9). Weakly foliated, pink, fine-grained biotite granite collected from a large outcrop along Whicher Brook, about $2.5 \mathrm{~km}$ upstream from the Wild Ammonoosuc River (Fig. 4C; Moench et al., 1995, discussed under site S-3). Three of four fractions of zircon are colinear with intercept ages of $450 \pm 2$ and $91 \pm 71 \mathrm{Ma}$ (MSWD \pm 0.33 ). The fourth fraction has a slightly older ${ }^{207} \mathrm{~Pb} /$ ${ }^{206} \mathrm{~Pb}$ age of $458 \mathrm{Ma}$ (Table 3).

I. Tunnel Brook pluton (sheared) (sample M-380-81; Fig. 10). Strongly foliated, fine-grained leucocratic biotite granite collected from the south side of the Wild Ammonoosuc River, about $11 \mathrm{~km}$ southeast of Swiftwater, NH (Fig. 4C; Moench et al., 1995, site S-3). This body lies to the east of the Moody Ledge pluton, on the opposite side of a sheet of Bethlehem Granodiorite. Billings (1937) correlated this body with his Moody Ledge granite. When Moench sampled it in 1981, he thought the rock was stratified metatuff, and Leo (1991, p. 39) considered it to be potassium-metasomatized felsic metatuff. Moench later found, however, that the foliated rock grades within about $40 \mathrm{~m}$ to more massive 

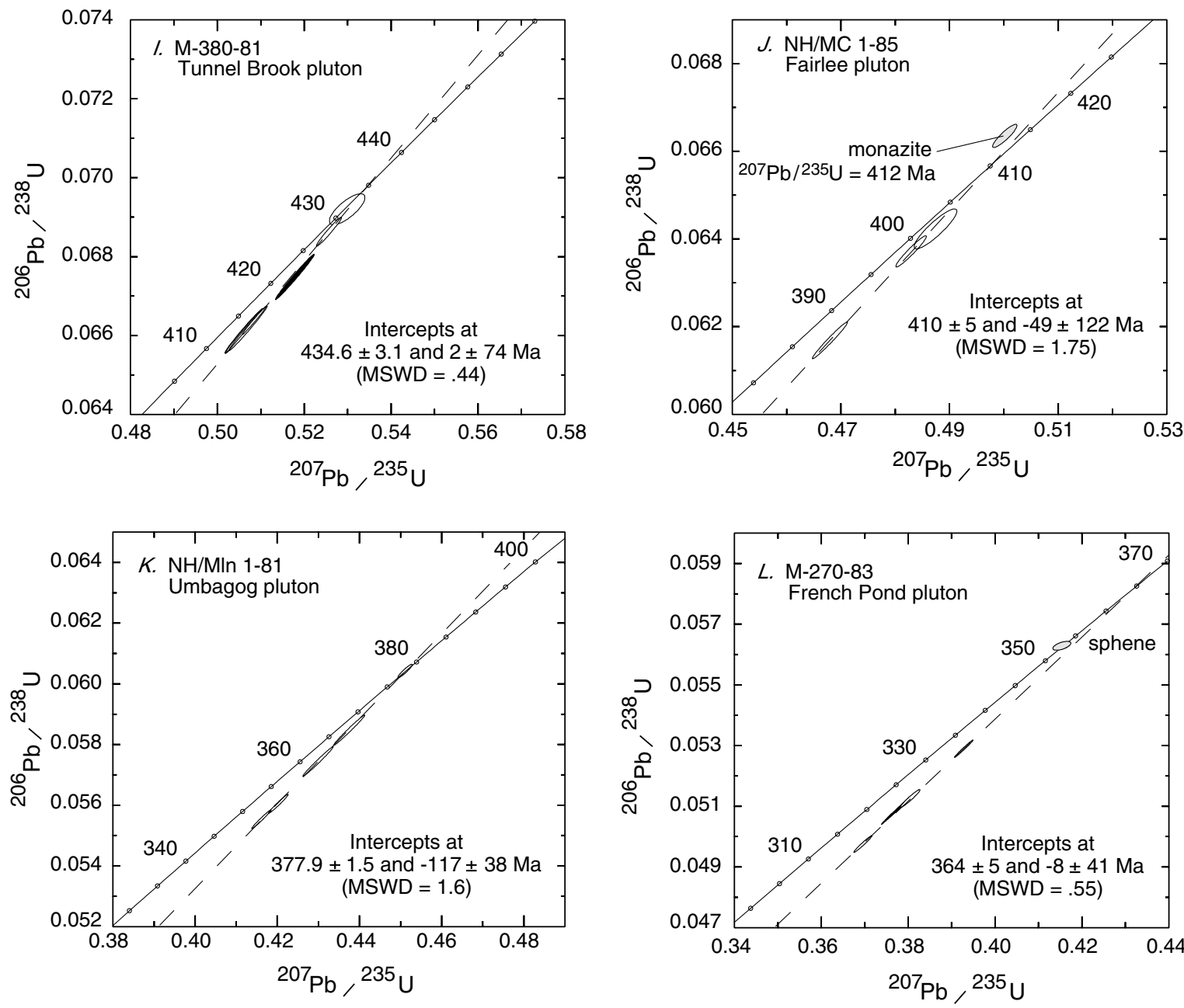

Fig. 10. U-Pb concordia plots for Tunnel Brook pluton $(I)$; Fairlee pluton $(J)$; Umbagog pluton $(K)$; and French Pond pluton $(L)$. Darkened data not incorporated in calculations; see text for explanation.
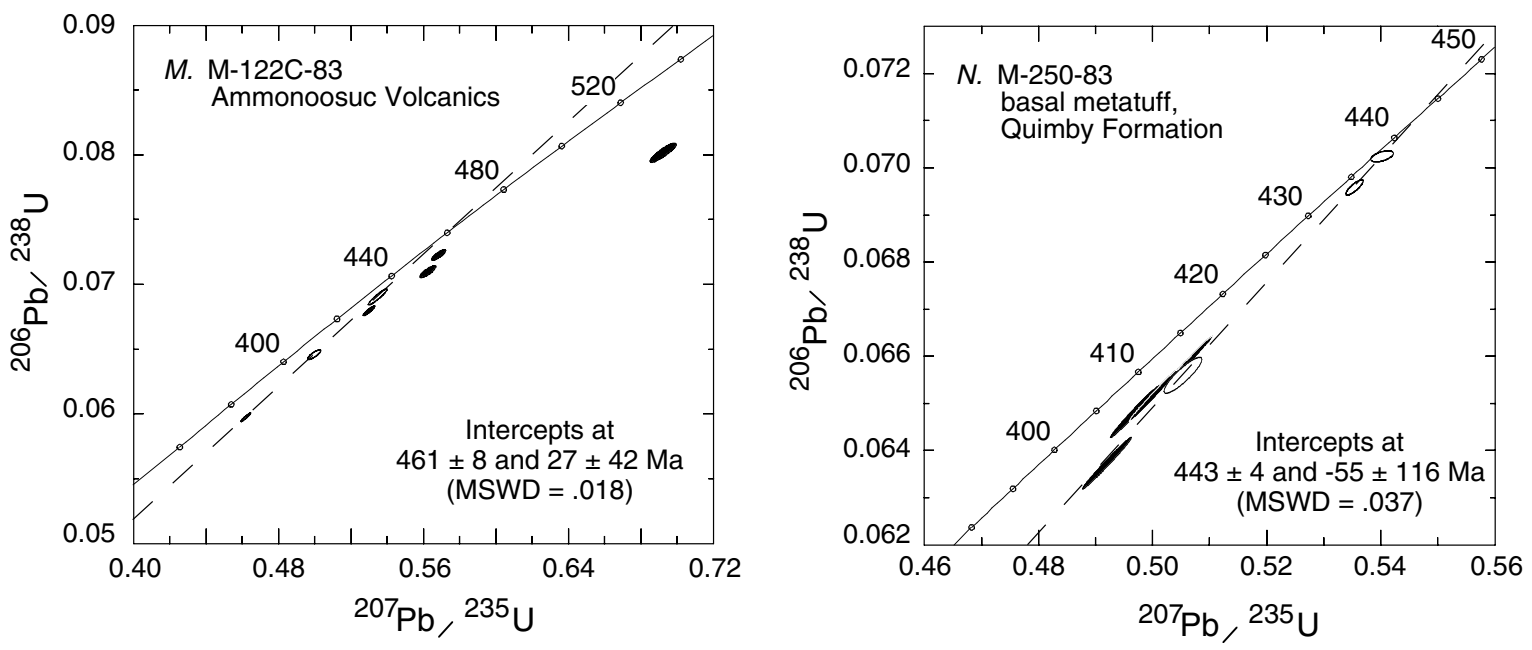

Fig. 11. U-Pb concordia plots for felsic metatuff from probable uppermost Ammonoosuc Volcanics (M); and basal felsic metatuff from Quimby Formation $(N)$. Darkened data not incorporated in calculations; see text for explanation. 
pink granite that is identical to the predominant granite of the Moody Ledge pluton. He also recognized that the foliation is probably high-temperature ductile mylonite having many stringer-like silicic melt fractions. This type of foliation also occurs in the border zone of the eastern side of the Moody Ledge pluton.

$\mathrm{U}-\mathrm{Pb}$ data from four of five zircon fractions from the Tunnel Brook pluton yielded a linear array with intercept ages of about $435 \pm 3$ and $2 \pm 74 \mathrm{Ma}$ (MSWD = 0.44 ). These zircons are about $15 \mathrm{~m}$.y. younger than zircons dated from the Moody Ledge pluton. Given the extremely resistant, refractory nature of zircon, it is unlikely that the 435-Ma zircons have been totally reset from $450 \mathrm{Ma}$. They may have formed during hightemperature shearing of the granite, with no inheritance from older seed grains. Alternatively, the rock may be part of a young (435 Ma) granite body emplaced either separately from the Moody Ledge pluton, or as part of an originally composite Moody Ledge pluton. More work is required to understand the origin of the sheared rock.

J. Fairlee pluton (sample NH/MC 1-85; Fig. 10). Foliated, medium-grained, biotite granite collected from a large outcrop on the west side of Vermont Route 5 about $2 \mathrm{~km}$ southwest of Piermont, NH (Moench et al., 1995, Fig. 4, discussed under site D-9). Three fractions of zircon, including one composed of rim material removed by abrasion, form a linear array with intercept ages of $410 \pm 5$ and $-49 \pm 122$ Ma $(M S W D=1.75)$. Isotopic data obtained from one grain of monazite is slightly reversely discordant, with a ${ }^{207} \mathrm{~Pb} /{ }^{235} \mathrm{U}$ age of $412 \pm 1 \mathrm{Ma}$. These ages agree with data from Kohn et al. (1992) who obtained a zircon age of $407 \pm 10 \mathrm{Ma}$ for the Bethlehem Granodiorite using the SHRIMP ion microprobe.

K. Umbagog pluton (sample NH/Mln 1-81; Fig. 10). Massive, medium-grained alkali gabbro (border facies of pluton) collected from a roadcut on the south side of Maine Route 26, about $2 \mathrm{~km}$ northwest of Upton, Maine (Fig. 4B; Moench et al., 1995, site D-5). Four large fractions and one small fraction of zircon were analyzed from quartz monzodiorite of the Umbagog pluton. The four large fractions yielded isotopic data that are slightly discordant and have ${ }^{207} \mathrm{~Pb} /{ }^{206} \mathrm{~Pb}$ ages of 383-387 Ma, whereas data from the small fraction are concordant at $378 \mathrm{Ma}$. Thus, a regression through the five data points, essentially anchored at the concordant age of $378 \mathrm{Ma}$ has a lower intercept age of $-117 \pm 38$ Ma. We suggest that the large discordant fractions contain a small amount of inheritance, and that the age of the Umbagog pluton is $378 \pm 2 \mathrm{Ma}$ (uncertainty of the ${ }^{207} \mathrm{~Pb} /{ }^{206} \mathrm{~Pb}$ age from the small fraction).

L. French Pond pluton (sample M-270-83; Fig. 10). Massive, pink, variably textured biotite granite collected from an outcrop about $3.5 \mathrm{~km}$ southwest of Swiftwater, NH (Fig. 4C; Moench et al., 1995, site D-8). Four large zircon fractions yielded discordant data, with intercept ages of $364 \pm 5$ and $-8 \pm 41$ Ma (MSWD $=0.55$ ). Sphene from the same sample yielded concordant data with an age of about $351 \mathrm{Ma}$, interpreted to represent time of cooling through the sphene closure temperature of about $700{ }^{\circ} \mathrm{C}$.

M. Ammonoosuc Volcanics (sample M-122C-83; Fig. 11). Bed of fine-grained felsic metatuff in a well stratified sequence of Ammonoosuc Volcanics, exposed on a ridge crest about $2 \mathrm{~km}$ southwest of the north end of the Moody Ledge pluton (Fig. 4C; Moench et al., 1995, site $\mathrm{M}-9$ ). The locality is $30 \mathrm{~m}$ east of the unconformity at the base of the Lower Silurian Clough Quartzite. Although this setting suggests that the sampled rock is in the very upper part of the Ammonoosuc, a large quantity of overlying Ammonoosuc might have been eroded before deposition of the Clough.

Seven fractions of zircon from the Ammonoosuc were analyzed (Table 3). Isotopic data from one (of two) small fractions, plus two large, fine-grained fractions are colinear with intercept ages of $461 \pm 8$ and $27 \pm 42 \mathrm{Ma}$ $(\mathrm{MSWD}=0.18)$. Other fractions have older ${ }^{207} \mathrm{~Pb} /{ }^{206} \mathrm{~Pb}$ ages (493-696 Ma). Because of the fine grain size of the analyzed zircons, we are unable to determine if the older ages are due to inheritance of radiogenic lead in xenocrystic cores or to contamination in the volcanic rock by detrital zircon.

N. Basal metatuff in Quimby Formation (sample M250C-83; Fig. 11). Bed, about $10 \mathrm{~m}$ thick, of mediumgrained biotite-quartz-plagioclase granofels interpreted as felsic metatuff collected from near the base of a cascade in the Ammonoosuc River just downstream from the covered bridge at Bath, NH (Fig. 4C; Moench et al., 1995, site M-10). The sample was collected from the approximate middle of the bed, which contains a few percent of black slate and metasiltstone slivers derived from the immediately underlying Partridge Formation. Isotopic data from four large zircon fractions are discordant and scattered. Data from three small splits are less discordant and colinear, with intercept ages of $443 \pm 4 \mathrm{Ma}$, interpreted as the time of extrusion, and $-55 \pm 116 \mathrm{Ma}(\mathrm{MSWD}=0.37)$.

\section{References}

Aleinikoff, J.N., 1977. Petrochemistry and tectonic setting of the Ammonoosuc Volcanics, New Hampshire-Vermont. Geological Society of America Bulletin 88, 1546-1552.

Aleinikoff, J.N., Winegarden, D.L., Walter, M., 1990. U-Pb ages of rims of zircon: a new analytical method using the air-abrasion technique. Chemical Geology (Isotope Geoscience Section) 80, 351-363.

Aleinikoff, J.N., Walter, M., Fanning, M.C., 1995. U-Pb ages of zircon, monazite, and sphene from rocks of the Massabesic Gneiss Complex and Berwick Formation, New Hampshire and Massachusetts. Geological Society of America Abstracts with Programs 27 (1), 26 
Ando, C.J. et al., 1984. Crustal profile of a mountain belt: COCORP deep seismic reflection profiling in New England Appalachians, and implications for architecture of convergent mountain chains. Bulletin of the American Association of Petroleum Geologists 68, 819-837.

Ayuso, R.A., 1986. Pb isotopic evidence for distinct sources of granite and for distinct basements in the northern Appalachians, Maine. Geology 14, 322-325.

Ayuso, R.A., 1989. Geochemistry of the Catheart Mountain porphyry copper deposit. In: Tucker, R.D., Marvinney, R.G. (Eds.), Studies in Maine Geology, vol. 4: Augusta, Maine Geological Survey, pp. $139-162$.

Ayuso, R.A., Bevier, M.L., 1991. Regional differences in Pb isotopic compositions of feldspars in plutonic rocks of the northern Appalachian Mountains, USA, and Canada: a geochemical method of terrane correlation. Tectonics 10 (1), 191-212.

Barker, F., Farmer, G.L., Ayuso, R.A., Plafker, G., Lull, J.S., 1992. The $50 \mathrm{Ma}$ granodiorite of the eastern Gulf of Alaska: melting in an accretionary prism in the forearc. Journal of Geophysical Research 97 (B5), 6757-6778.

Barr, S.M., White, C.E., 1991. Revised stratigraphy of the Avalon terrane of southern New Brunswick (Field trip Guidebook): New England Intercollegiate Geological Conference, 83rd Annual Meeting, Princeton, Maine, pp. 1-12.

Berry, W.B.N., 1962. On the Magog, Quebec, graptolites. American Journal of Science 260, 142-148.

Billings, M.P., 1935, Geology of the Littleton and Moosilauke quadrangles, New Hampshire Planning and Development Commission, Concord, NH, $51 \mathrm{pp}$.

Billings, M.P., 1937. Regional metamorphism of the Littleton-Moosilauke area, New Hampshire. Geological Society of America Bulletin 48, 463-566.

Billings, M.P., 1956, The geology of New Hampshire, Part II, Bedrock geology, New Hampshire State Planning and Development Commission, Concord, NH, 203 pp., map scale 1:250,000.

Boone, G.M., 1973. Metamorphic stratigraphy, petrology, and structural geology of the Little Bigelow Mountain map area. Maine Geological Survey Bulletin 24, 136.

Boone, G.M., Boudette, E.L., 1989. Accretion of the Boundary Mountains terrane within the northern Appalachian orthotectonic zone. In: Horton Jr., J.W., Rast, N.M. (Eds.), Melanges and olistostromes of the US Appalachians, Geological Society of America Special Paper 288, pp. 17-42.

Boone, G.M., Doty, D.T., Heizler, M.T., 1989. Hurricane Mountain Formation melange: Description and tectonic setting of a Penobscottian accretionary complex. In: Tucker, R.D., Marvinney, R.G. (Eds.), Studies in Maine Geology, vol. 2, Maine Geological Survey, Augusta, Maine, pp. 33-83.

Bothner, W.A., Hussey II, A.M., 1999. Norumbega connection: Casco Bay, Maine to Massachusetts? In: Ludman, A., West Jr., D.P. (Eds.), Norumbega Fault Systems of Northern Appalachians, Geological Society of America Special Paper no. 331, pp. 59-72.

Boucot, A.J., 1969. Geology of the Moose River and Roach River synclinoria, northwestern Maine. Maine Geological Survey Bulletin (21), 117.

Boucot, A.J., 1973. Early Paleozoic brachiopods of the Moose River synclinorium, Maine, US Geological Survey Professional Paper 784, 81 pp., 23 plates.

Boucot, A.J., 1993. Comments on Cambrian-to-Carboniferous biogeography and its implications for the Acadian orogeny. In: Roy, D.C., Skehan, J.W. (Eds.), The Acadian Orogeny-Recent studies in New England, Maritime Canada, and the autochthonous foreland, Geological Society of America Special Paper 275, pp. $41-49$.

Boudette, E.L., 1978. Pre-Silurian stratigraphic succession in central western Maine, Dartmouth College, Ph.D. dissertation, Hanover, New Hampshire, 346 pp.
Boudette, E.L., 1982. Ophiolite assemblage of early Paleozoic age in central-western Maine. In: St. Julien, P., Beland, J. (Eds.), Major structural zones and faults of the northern Appalachians, Geological Association of Canada Special Paper 24, pp. 209-230.

Boudette, E.L., 1991. Geologic map of the Kennebago Lake quadrangle, Franklin County, Maine, US Geological Survey Miscellaneous Investigations Series Map I-2058, scale 1:62,500; pamphlet, $12 \mathrm{pp}$.

Boudette, E.L., Boone, G.M., 1982. Diamictite of the Chain Lakes massif, Maine: a possible metasuevite. Geological Society of America Abstracts with Programs 14 (7), 448.

Boudette, E.L., Boone, G.M., Goldsmith, R., 1989. The Chain Lakes massif and its contact with a Cambrian ophiolite and a Caradocian granite (1989 Guidebook), New England Intercollegiate Geological Conference, 81st Annual Meeting, Farmington, Maine, pp. 98-121.

Bourque, P., Malo, M., Kirkwood, D., 2000. Paleogeography and tectono-sedimentary history at the margin of Laurentia during Silurian to earliest Devonian time: the Gaspé belt. Geological Society of America Bulletin 112 (1), 4-20.

Bradley, D.C., 1983. Tectonics of the Acadian orogeny in New England and adjacent Canada. Journal of Geology 91, 381-400.

Bradley, D.C., Tucker, R.D., Lux, D.R., Harris, R.G., McGregor, D.C., 1998. Migration of the Acadian orogen and foreland basin across the northern Appalachians, US Geological Survey OpenFile Report 98-770, 79 pp.

Cawood, P.A., Suhr, G., 1992. Generation and obduction of ophiolites: constraints from the Bay of Islands Complex, western Newfoundland. Tectonics 11 (4), 884-897.

Coish, R.A., Rogers, N.W., 1987. Geochemistry of the Boil Mountain ophiolitic complex, northwest Maine, and tectonic implications. Contributions to Mineralogy and Petrology 97, 51-65.

Copeland, M.J., Berdan, J.M., 1977. Silurian and Early Devonian Beyrichacean ostrocode provincialism in eastern North America. Geological Survey of Canada Paper 77-1B, 15-24.

Corfu, F., 1996. Multistage zircon and titanite growth and inheritance in an Archean gneiss complex, Winnipeg River Subprovince, Ontario. Earth and Planetary Science Letters 141, 175-186.

Cousineau, P.A., 1991. The Riviere des Plante ophiolitic melange: tectonic setting and melange formation in the Quebec Appalachians. Journal of Geology 99, 81-96.

Cousineau, P.A., 1994. Subaqueous deposits in an Ordovician fore-arc basin: an example from the Saint-Victor Formation, Quebec Appalachians, Canada. Journal of Sedimentary Research A 64 (4), 867-880.

Cousineau, P.A., St. Julien, P., 1992. The Saint-Daniel melange: evolution of an accretionary complex in the Dunnage terrane of the Quebec Appalachians. Teconics 11 (4), 898-909.

Cousineau, P.A., Tremblay, A., 1993. Acadian deformation in the southwestern Quebec Appalachians. In: Roy, D.C., Skehan, J.W. (Eds.), The Appalachian Orogeny-Recent Studies in New England, Maritime Canada, and the autochthonous foreland, Geological Society of America Special paper 275, pp. 85-99.

David, J., Marquis, R., Tremblay, A., 1993. U-Pb geochronology of the Dunnage zone, in the southwestern Quebec Appalachians. Geological Society of America Abstracts with Programs 25 (6), A485.

Davidek, K., Landing, Ed., Bowring, S.A., Westrop, S.R., Rushton, A.W.A., Fortey, R.A., Adrian, J.M., 1998. New Upper Cambrian $\mathrm{U}-\mathrm{Pb}$ date from Avalonian Wales and age of Cambrian-Ordovician boundary. Geological Magazine 135, 305-309.

Doll, C.G., Cady, W.M., Thompson Jr., J.B., Billings, M.P., 1961. Centennial geologic map of Vermont: Montpelier, Vermont Geological Survey, scale 1:250,000.

Dorais, M.J., Paige, M.L., 1999. The New Hampshire Plutonic Series: windows to New England basement complexes and implications for magma heat sources. Geological Society of America Abstracts with Programs 31 (2), A-13. 
Dubé, B., Dunning, G.R., Lauzière, K., Roddick, J.C., 1996. New insights into the Appalachian orogen from geology and geochronology along the Cape Ray fault zone, southwest Newfoundland. Geological Society of America Bulletin 108 (1), 101-116.

Dunning, G.R., Cousineau, P.A., 1990. U/Pb ages of single zircons from Chain Lakes massif and a correlative unit in ophiolitic melange in Quebec. Geological Society of America Abstracts with Programs 22 (2), 13.

Eisenberg, R.A., 1982. Chronostratigraphy and lithogeochemistry of Lower Paleozoic rocks from the Boundary Mountains, west-central Maine, University of California Ph.D. dissertation, Berkeley, CA, $180 \mathrm{pp}$.

Eric, J.H., Dennis, J.G., 1958. Geology of the Concord-Waterford area, Vermont. Vermont Geological Survey Bulletin 11, 66.

Finney, S.C., Ethington, R.L., 1992. Whiterockian graptolites and condonts from the Vinini Formation, Nevada. In: Webby, B.D., Laurie, J.R. (Eds.), Global Perspectives on Ordovician Geology. Balkema, Rotterdam, Brookfield, Netherlands, pp. 153-169.

Fitz, T.J., 1996. Geology of the Chickwolnepy intrusions in northern New Hamphire. In: van Baalen, M.R. (Ed.), Guidebook to Field Trips in Northern New Hampshire and Adjacent Regions of Maine and Vermont, Harvard University, New England Intercollegiate Geological Conference, 88th Annual Meeting, Cambridge, MA, pp. 39-57.

Fitz, T.J., 1999. Petrology and tectonic significance of the Chickwolnepy intrusions, Coos County, New Hampshire, University of Delaware Ph.D. dissertation, Newark, DE, 232 pp.

Fitz, T.J., 2002. Magmatism in an extensional setting within the Bronson Hill belt: Chickwolnepy intrusions of northern New Hampshire. In: Mitchell, C.E., Jacobi, R.D. (Eds.), Taconic Convergence-Orogen, Foredeep, and Cratonic Interactions. Journal of Physics and Chemistry of the Earth 27 (1-3), 97-108.

Foland, K.A., Loiselle, M.C., 1981. Oliverian syenites of the Pliny region, northern New Hampshire. Geological Society of America Bulletin 92 (Part 1), 179-188.

Fortey, R.A., Harper, D.A.T., Ingham, J.K., Owen, A.W., Rushton, A.W.A., 1995. A revision of Ordovician Series and Stages from the historical type area. Geological Magazine 132, 15-30.

Fyffe, L.R., McLeod, M.J., Ruitenberg, A.A., 1991. A geotraverse across the St. Croix-Avalon boundary, southern New Brunswick (Field trip Guidebook): New England Intercollegiate Geological Conference, 83rd Annual Meeting, Princeton, Maine, pp. 13-54.

Gates, O., Moench, R.H., 1981. Bimodal Silurian and Lower Devonian volcanic rock assemblages in the Eastport-Machias area, Maine: US Geological Survey Professional Paper 1148, 32 pp.

Getty, S.R., Gromet, L.P., 1992a. Geochronological constraints on ductile deformation, crustal extension, and doming about a basement-cover boundary, New England Appalachians. American Journal of Science 292, 350-397.

Getty, S.R., Gromet, L.P., 1992b. Evidence for extension at the Willimanitic dome, Connecticut: implications for the Late Paleozoic tectonic evolution of the New England Appalachians. American Journal of Science 292, 398-420.

Green, J.C., 1964, Stratigraphy and structure of the Boundary Mountains anticlinorium in northern New Hampshire and northwestern Maine, Geological Society of America Special Paper 77, 78 pp.

Guidotti, C.V., 1977. Geology of the Oquossuc 15' quadrangle, westcentral Maine, Maine Geological Survey Open-File Report 77-2, 26 pp.

Hadley, J.B., 1942. Stratigraphy, structure, and petrology of the Mount Cube area, New Hampshire. Geological Society of America Bulletin 53, 113-176.

Hall, B.A., 1970. Stratigraphy of the southern end of the Munsungun anticlinorium. Maine Geological Survey Bulletin 22, 63.

Harper, D.A.T., Mac Niocaill, C., Williams, S.H., 1996. The palaeogeography of early Ordovician Iapetus terranes: an integration of faunal and palaeomagnetic constraints. Palaeogeography, Palaeoclimatology, Palaeoecology 121, 297-312.

Harwood, D.S., 1973. Bedrock geology of the Cupsuptic and Arnold Pond quadrangles, west-central Maine. US Geological Survey Bulletin 1346, 90.

Harwood, D.S., Berry, W.B.N., 1967, Fossiliferous Lower Paleozoic rocks in the Cupsuptic quadrangle, west-central Maine, US Geological Survey Professional Paper 575-D, pp. D16-D23.

Hepburn, J.C., Dunning, G.R., Hon, R., 1995. Geochronolgy and regional tectonic implications of Silurian Deformation in the Nashoba terrane, southeastern New England, USA. In: Hibbard, J.P., van Staal, C.R., Cawood, P.A. (Eds.), Current Perspectives in the Appalachian-Caledonian Orogen, Geological Association of Canada, Special Paper 41, pp. 349-366.

Hollocher, K., 1993. Geochemistry and origin of volcanics in the Bronson Hill anticlinorium, west-central Massachusetts. American Journal of Science 293, 671-721.

Hollocher, K., Bull, J., Robinson, P., 2002. Geochemistry of the metamorphosed Ordovician Taconic magmatic arc. In: Mitchell, C.E., Jacobi, R.D. (Eds.), Taconic Convergence-Orogen, Foredeep, and Cratonic Interactions. Journal of Physics and Chemistry of the Earth 27 (1-3), 5-45.

Holtzman, B., Trzcienski, W., Gromet, L.P., 1996. New tectonic constraints on the Boil Mountain Complex/Chain Lakes unit contact, central western Maine: Geological Society of America Annual Meeting Abstract with Programs vol. 29, p. 65.

Hughes, S., Luetgert, J.H., 1991. Crustal structure of the western New England Appalachians and the Adirondack Mountains. Journal of Geophysical Research 96 (B10), 16,471-16,494.

Hussey II, A.M., Bothner, W.A., 1995. Geology of the Coastal lithotectonic belt, southwestern Maine and southeastern New Hampshire. In: Hussey II, A.M. and Johnston, R.A. (Eds.), Guidebook to Field Trips in Southern Maine and Adjacent New Hampshire, Bowdoin College, New England Intercolletiate Geological Conference, 87th Annual Meeting, Brunswick, ME, pp. 211-228.

Hussey II, A.M., Ludman, A., Bothner, W.A., 1999. Fredericton and Merrimack troughs: Once one or always two? Geological Society of America Abstracts with Programs 31 (2), A-25.

Karabinos, P., Tucker, R.D., 1992. The Shelburne Falls arc in western Massachusetts and Connecticut. Geological Society of America Abstracts with Programs 24, A288.

Karabinos, P., Gromet, P., 1993. Application of single-grain zircon evaporation analyses to detrital grain studies and age discrimination in igneous suites. Geochimica et Cosmochimica Acta 57, 42574267.

Karabinos, P., Thompson Jr., J.B., 1997. Basement-cover relationships in southern Vermont and adjacent New Hampshire. In: Grover, T.W., Mango, H.N., Hasenohr, E.J. (Eds.), Guidebook to Field Trips in Vermont and adjacent New Hampshire and New York: Castleton, Vermont, Castleton State College, 89th Annual Meeting, New England Intercollegiate Geological Conference, pp. B3, $1-20$.

Karabinos, P., Samson, S.D., Hepburn, J.C., Stoll, H.M., Aleinikoff, J.N., 1996. The Taconic orogeny in New England: collision between Laurentia and the Shelburne Falls arc. Geological Society of America Abstracts with Programs 28 (3), 70.

Karabinos, P., Samson, S.D., Hepburn, J.C., Stoll, H.M., 1998. Taconian orogeny in the New England Appalachians: collision between Laurentia and the Shelburne Falls arc. Geology 26 (3), 215-218

Karabinos, P., Samson, S.D., Hepburn, J.C., Stoll, H.M., 1999. Taconian orogeny in the New England Appalachians: collision between Laurentia and the Shelburne Falls arc: Reply. Geology 27 (4), 382.

Keppie, J.D., 1989. North American terranes and their accretionary history. In: Dallmeyer, R.D. (Ed.), Terranes in the Circum-Atlantic 
Paleozoic orogens: Geological Society of America Special Paper vol. 230, pp. 151-191.

Kim, J., Jacobi, R.D., 1996. Geochemistry and tectonic implications of Hawley Formation meta-igneous units. American Journal of Science 296, 1126-1174.

Kohn, M.J., Orange, D.L., Spear, F.S., Rumble III, D., Harrison, M.T., 1992. Pressure, temperature, and structural evolution of west-central New Hampshire-Hot thrusts over cold basement. Journal of Petrology 33, 521-556.

Kolata, D.R., Huff, W.D., Bergström, S.M., 1996. Ordovician Kbentonites of eastern North America, Geological Society of America Special Paper vol. 313, 84 pp.

Krogh, T.E., 1973. A low-contamination method for hydrothermal decomposition of zircon and extraction of $\mathrm{U}$ and $\mathrm{Pb}$ for isotopic age determination. Geochimica et Cosmochimica Acta 37, 485494.

Kusky, T.M., Chow, J.S., Bowring, S.A., 1997. Age and origin of the Boil Mountain ophiolite and Chain Lakes massif, Maine: implications for the Penobscottian orogeny. Canadian Journal of Earth Sciences 34, 646-654.

Llamas, A.P., Hepburn, J.C., 2001. The coastal volcanic belt (CVB), easternmost Maine: Geochemistry and tectonic setting. Geological Society of America Abstracts with Programs 33 (1), A-27.

Laird, J., 1996. Taconian metamorphism in Vermont and Quebec: a summary. Geological Society of America Programs with Abstracts 28 (3), 74.

Laird, Jo, Trzcienski Jr., W.E., Bothner, W.A., 1993. High-pressure, Taconian, and susequent polymetamorphism of southern Quebec and northern Vermont. In: Cheney, J.T., Hepburn, J.C. (Eds.), Field trip guidebook for the northeastern United States-1993 Boston GSA, vol. 2, Department of Geology and Geography, University of Massachusetts, Amherst, MA, Contribution no. 67, O-1 to O-32.

Landing, Ed., Bowring, S.A., Fortey, R.A., Davidek, K., 1997. U-Pb zircon date from Avalonian Cape Breton Island and geochronologic calibration of the Early Ordovician. Canadian Journal of Earth Science 34, 724-730.

Lebel, D., Tremblay, A., 1993. Gèologie de la région de Lac-Méganitc (Estrie): Quebec Ministère de l'Énergie et des Ressources, DV 9304; Échelle 1:50,000.

Leo, G.W., 1985. Trondhjemite and metamorphosed quartz keratophyre tuff of the Ammonoosuc Volcanics (Ordovician), western New Hampshire and adjacent Vermont and Massachusetts. Geological Society of America Bulletin 96, 1493-1507.

Leo, G.W., 1991. Oliverian domes, related plutonic rocks, and mantling Ammonoosuc Volcanics of the Bronson Hill anticlinorium, New England Appalachians, US Geological Survey Professional Paper 1516, 92 pp.

Liss, M.J., van der Pluijm, B.A., Van der Voo, R., 1993. Avalonian proximity of the Ordovician Miramichi terrane, northern New Brunswick, northern Appalachians: Paleomagnetic evidence for rifting and back-arc basin formation at the southern margin of Iapetus. Tectonophysics 227, 17-30.

Ludman, A., 1991a. Stratigraphy of the Miramichi terrane in eastern Maine (Field trip Guidebook): New England Intercollegiate Geological Conference, 83rd Annual Meeting, Princeton, ME, pp. $338-357$.

Ludman, A., 1991b. Revised stratigraphy of the Cookson Group (St. Croix terrane), eastern Maine and southwestern New Brunswick (Field trip Guidebook): New England Intercollegiate Geological Conference, 83rd Annual Meeting, Princeton, ME, pp. 114132.

Ludman, A., Hopeck, J.T., Brock, P.C., 1993. Nature of the Acadian orogeny in eastern Maine. In: Roy, D.C., Skehan, J.W. (Eds.), The Acadian Orogeny-Recent Studies in New England, Maritime Canada, and the Autochthonous Foreland: Geological Society of America Special Paper vol. 275, pp. 67-84.
Ludman, A., Idleman, B., 1998. The Berry Brook gabbro-diorite: NWmost Siluro-Devonian mafic magmatism in the coastal lithotectonic belt, Maine. Geological Society of America Abstracts with Programs 30 (1), 58.

Ludwig, K.R., 1991a. PBDAT: A computer program for processing $\mathrm{Pb}-\mathrm{U}-\mathrm{Th}$ isotope data, Version 1.20: US Geological Survey OpenFile Report 88-542, Revision of March 19, 1991, 34 pp.

Ludwig, K.R., 1991b. ISOPLOT: A plotting and regression program for radiogenic-isotope data: US Geological Survey Open-File Report 91-445, 41 pp.

Lyons, J.B., Aleinikoff, J.N., Zartman, R.E., 1986. Uranium-thoriumlead ages of the Highlandcroft Plutonic Suite, northern New England. American Journal of Science 286 (6), 489-509.

Lyons, J.B., Boudette, E.L., Aleinikoff, J.N., 1982. The Avalon and Gander zones in central and eastern New England. In: St.-Julien, P., Béland, J. (Eds.), Major structural zones and faults in the Northern Appalachians, Geological Association of Canada Special Paper vol. 24, pp. 43-66.

Lyons, J.B., Campbell, J.G., Erikson, J.P., 1996. Gravity signatures and geometric configurations of some Oliverian plutons: their relation to Acadian structures. Geological Society of America Bulletin 108 (7), 872-882.

Lyons, J.B., Bothner, W.A., Moench, R.H., Thompson Jr., J.B., 1997. Bedrock geologic map of New Hampshire, US Geological Survey; scale $1: 250,000$.

Mac Niocaill, C., van der Pluijm, B.A., Van der Voo, R., 1997. Ordovician paleogeography and the evolution of the Iapetus ocean. Geology 25 (2), 159-162.

Malo, M., Kirkwood, D., DeBroucker, G., St.-Julien, p., 1992. A reevaluation of the position of the Baie Verte-Brompton line in the Quebec Appalachians: the influence of Middle Devonian strike-slip faulting in Gaspé Peninsula. Canadian Journal of Earth Science 29, $1265-1273$.

Marvinney, R.G., 1989. Thrust and strike-slip faults near Jackman, Maine. In: Tucker, R.D., Marvinney, R.G. (Ed.), Studies in Maine Geology, vol. 2, Augusta, Maine Geological Survey, pp. 173-185.

McKenna, J.M., Hepburn, J.C., Hon, R., 1993. Geochemistry of the Newbury Volcanic Complex, northeastern Massachusetts. Geological Society of America Program with Abstracts 25 (2), 63.

Milton, D.J., 1961, Geology of the Old Speck Mountain quadrangle, US Geological Survey Open-File Report, Maine, 190 pp.

Milton, D.J., 1968, Reconnaissance geologic map of part of the Milan quadrangle, New Hampshire-Maine, and the Percy quadrangle, US Geological Survey Open-File Map, New Hampshire, scale $1: 62,500$

Moench, R.H., 1969, The Quimby and Greenvale Cove Formations in western Maine, US Geological Survey Bulletin 1274-L, 17 pp.

Moench, R.H., 1971. Geologic map of the Rangeley and Phillips quadrangles, Franklin and Oxford Counties, US Geological Survey Miscellaneous Geologic Investigations Map I-605, Maine, scale $1: 62,500$.

Moench, R.H., 1990. The Piermont allochthon, northern Connecticut Valley area, New England: preliminary description and resource implications. In: Slack, J.F. (Ed.), Summary results of the Glens Falls CUSMAP project, US Geological Survey Bulletin 1887, New York, Vermont, and New Hampshire, pp. J1-J23.

Moench, R.H., 1996a. Stratigraphic basis for the Piermont-Frontenac allochthon, Bath, New Hampshire, to Bradford, Vermont. In: van Baalen, M.R. (Eds.), Guidebook to field trips in northern New Hampshire and adjacent regions of Maine and Vermont, Harvard University, New England Intercollegiate Geological Conference, 88th Annual Meeting, Cambridge, MA, pp. 133-153.

Moench, R.H., 1996b. Role of Silurian extension in the northern New England Appalachians: an example of supra-subduction rifting? Geological Society of America Abstracts with Programs 28 (7), A-500. 
Moench, R.H., 1999. Nature of the Albee-Ammonoosuc contact in the Moore Reservoir area, New Hampshire and Vermont: PiermontFrontenac allochthon, embattled but thriving! In: Wright, S.H. (Ed.), Guidebook to Field Trips in Vermont and Adjacent Regions of New Hampshire and New York, University of Vermont, New England Intercollegiate geological Conference, 91st Annual Meeting, Burlington, VT, pp. 113-135.

Moench, R.H., Aleinikoff, J.N., 2001. Revised Middle Ordovician U$\mathrm{Pb}$ age for the volcanic Clear Stream Member, NE New Hampshire: regional impact. Geological Society of America Abstracts with Programs 33 (1), A-20.

Moench, R.H., Aleinikoff, J.N., Boudette, E.L., 2000. Revised Early Ordovician age for the ophiolitic Jim Pond Formation, NW Maine: tectonic history reappraised. Geological Society of America Abstracts with Programs 32 (1), A-60.

Moench, R.H., Boone, G.M., Bothner, W.A., Boudette, E.L., Hatch Jr., N.L., Hussey II, A.M., Marvinney, R.G., 1995. Geologic map of the Sherbrooke-Lewiston area, Maine, New Hampshire, Vermont, United States, and Quebec, Canada, with contributions to geochronology by J.N. Aleinikoff, US Geological Survey Miscellaneous Series Investigsations Map I-1898-D; scale 1:250,000, pamphlet, $56 \mathrm{p}$.

Moench, R.H., Boudette, E.L., Bothner, W.A., 1999. Tectonic lithofacies, geophysical, and mineral-resource-appraisal maps of the Sherbrooke-Lewiston area, Maine, New Hampshire, and Vermont, United States, and Canada, US Geological Survey Miscellaneous Investigation Series Maps I-1898-E, Maps A-D, scale 1:250,000, 107 pp., pamphlet.

Naylor, R.S., 1969. Age and origin of the Oliverian domes, centralwestern New Hampshire. Geological Society of America Bulletin $80,405-428$.

Neuman, R.B., 1967, Bedrock geology of the Shin Pond and Stacyville quadrangles, Penobscot County, US Geological Survey Professional Paper 524-I, I1-I37, Maine, map scale 1:62,500.

Neuman, R.B., 1973. Late Ordovician (Ashgillian) age of volcanic rocks, north-central Maine, in US Geological Survey Research, 1973, US Geological Survey Professional Paper 850, p. 165

Neuman, R.B., 1984. Geology and paleobiology of islands in the Ordovician Iapetus Ocean: review and implications. Geological Society of America Bulletin 95, 188-1201.

Neuman, R.B., 1987. Type section of the Early Ordovician Shin Brook Formation and evidence of the Penobscot orogeny, northern Penobscot County, Maine, Geological Society of America Centennial Field Guide-Northeastern Section, pp. 307-309.

Neuman, R.B., 1991. Comment on "tectonic history of the Lunksoos composite terrane in the Maine Appalachians". Tectonics 10 (3), 643-645.

Neuman, R.B., Palmer, A.R., Dutro Jr., J.T., 1989. Paleontological contributions to paleozoic paleogeographic reconstructions of the Appalachians. In: Hatcher Jr., R.D., Thomas, W.A., Viele, G.W. (Eds.), The Geology of North America, vol. F-2, The AppalachianQuachita Orogen in the United States, Geological Society of America, pp. 375-384.

Osberg, P.H., Hussey II, A.M., Boone, G.M., 1985. Bedrock geologic map of Maine: Augusta, Maine Geological Survey, scale 1:500,000.

Pidgeon, R.T., Bosch, D., Bruguier, O., 1996. Inherited zircon and titanite $\mathrm{U}-\mathrm{Pb}$ systems in an Archean syenite from southwestern Australia: implications for U-Pb stability of titanite. Earth and Planetary Science Letters 141, 187-198.

Pogorzelski, B.K., 1983. Petrochemistry and petrogenesis of the Highlandcroft Plutonic Series, New Hampshire, Vermont, and Maine, Dartmouth College M.S. thesis, Hanover, NH, 97 pp.

Potts, S.P., van der Pluijm, B.A., Van der Voo, 1993. Paleomagnetism of the Ordovician Bluffer Pond Formation: paleogeographic implications for the Munsungun terrane of northern Maine. Journal of Geophysical Research 95 (B5), 7987-7996.
Potts, S.P., van der Pluijm, B.A., Van der Voo, 1995. Paleomagnetism of the Pennington terrane: a near-Laurentian back arc basin in the Maine Appalachians. Journal of Geophysical Research 100 (B7), 10,003-10,011.

Rankin, D.W., 1996. Bedrock geology of the Littleton, Vermont-New Hampshire 15-min quadrangle northwest of the Ammonoosuc fault, with a section on the analytical methods and isotopic age investigation of pegmatitic metadiorite of the intrusive suite of Commerford dam. In: Tucker, R.D., van Baalen, M.R. (Eds.), Guidebook to Field Trips in Northern New Hampshire and Adjacent Regions of Maine and Vermont, Harvard University, New England Intercollegiate Geological Conference, 88th Annual Meeting, Cambridge, MA, pp. 5-37.

Rankin, D.W., 2001. Ordovician sedimentary breccia and magnetitecoticule metasilttone, Northeast Kingdom, Vermont. Geological Society of America Abstracts with Programs 53 (1), A-5.

Rankin, D.W., Tucker, R.D., 1999. Age and contact relations of the Lost Nation pluton, upper Connecticut Valley: implications for the Piermont-Frontenac allochthon. EOS, Transactions, American Geophysical Union, 1999 Spring Meeting Supplement 80 (17r), 5358.

Ratcliffe, N.M., Hames, W.F., Stanley, R.S., 1999. Taconic orogeny in the New England Appalachians: collision between Laurentia and the Shelburne Falls arc: comment. Geology 27 (4), 831.

Robinson, P., Tucker, R.D., Bradley, D.C., Berry, H.N.IV, Osberg, P.H., 1998. Paleozoic orogens in New England, USA: Stockholm, GFF, vol. 120, pp. 119-148.

Roy, D.C., Mencher, E., 1976. Ordovician and Silurian stratigraphy of northeastern Aroostook County, Maine. In: Page, L.R. (Ed.), Contributions to the Stratigraphy of New England, Geological Society of America Memoir 148, pp. 25-52.

Ross Jr., R.J., Ethington, R.L., 1992. North American Whiterock Series suited for global correlation. In: Webby, B.D., Laurie, J.R. (Eds.), Global Perspectives on Ordovician Geology. Balkema/ Brookfield, Rotterdam/Netherlands, pp. 135-152.

Ross Jr., R.J., Hintze, L.F., Ethington, R.L., Miller, J.F., Taylor, M.E., Repetski, J.E., 1998. The Ibexian, Lowermost Series in the North American Ordovician, with a section on echinoderm biostratigraphy by Sprinkle, James, Guensburg, T.E.: US Geological Survey Professional Paper 1597A, pp. 1-50.

Royden, L.H., 1993a. The tectonic expression of slab pull at convergent boundaries. Tectonics 12 (2), 303-325.

Royden, L.H., 1993b. Evolution of retreating subduction boundaries formed during continental collision. Tectonics 12 (3), 629-638.

Schumacher, J.C., 1988. Stratigraphy and geochemistry of the Ammonoosuc Volcanics, central Massachussetts and southwestern New Hampshire. American Journal of Science 288, 619-663.

Seaman, S.J., Wobus, R.A., Wiebe, R.A., Lubick, N., Bowring, S.A., 1995. Volcanic expression of bimodal magmatism: the Cranberry Island-Cadillac Mountain Complex, coastal Maine. Journal of Geology 103, 301-311.

Sevigny, J.H., Hanson, G.H., 1995. Late Taconian and pre-Acadian history of New England Appalachians of southwestern Connecticut. Geological Society of America Bulletin 107 (4), 487-498.

Shaw, H.F., Wasserburg, J.G., 1984. Isotopic constraints on the origin of Appalachian mafic complexes. American Journal of Science 281, 319-349.

Shride, A.F., 1976. Stratigraphy and correlation of the Newbury Volcanic Complex, northeastern Massachusetts: Geological Society of America Memoir 148, pp. 147-177.

Skehan, J.W., 2001. Roadside Geology of massachusetts. Mountain Press Publishing Co., Montana, Missoula, 378 p.

Skehan, J.W., Rast, N., 1992. The Avalon superterrane and the enigma of Nashoba. Geological Society of America Abstract with Programs 24, A-288.

Skehan, J.W., Rast, N., 1995. Late Proterozoic to Cambrian evolution of the Boston Avalon terrane. In: Hibbard, J.P., van Staal, C.R., 
Cawood, P.A. (Eds.), Current Perspectives in the AppalachianCaledonian Orogen: Geological Association of Canada, Special Paper 41, pp. 207-225.

Slack, J.F., Swinden, H., LeHuray, A.P., 1991. Lead isotopes in massive sulfide deposits of the Northern Appalachian orogen. Geological Society of America Abstracts with Programs 23 (1), 129.

Slack, J.F., Foose, M.P., Shulz, K.J., Busby, C.J., Ayuso, R.A., Sinha, A.K., Harris, A.G., 1999. The Bald Mountain terrane, Aroostook County, Maine: a composite island arc assemblage exotic to the Ordovician Winterville Formation. Geological Society of America Abstracts with Programs 31 (2), A-68.

Soesoo, A., Bons, P.D., Gray, D.R., Foster, D.A., 1997. Divergent double subduction-Tectonic and petrologic consequences. Geology 25 (8), 755-758.

Stacey, J.S., Kramers, J.D., 1975. Approximation of terrestrial lead isotope evolution by a two-stage model. Earth and Planetary Science Letters 26, 207-226.

Steiger, R.H., Jäger, E., 1977. Subcommission on geochronology, convention on the use of decay constants in geo- and cosmochronology. Earth and Planetary Science Letters 36, 359-362.

Stanley, R.S., Ratcliffe, N.M., 1985. Tectonic synthesis of the Taconian orogeny in western New England. Geological Society of America Bulletin 96, 1227-1250.

Stewart, D.B., Wright, B.E., Unger, J.D., Phillips, J.D., Hutchinson, D.R., 1993. Global geoscience traverse 8: Quebec-Maine-Gulf of Maine transect, southeastern Canada, northeastern United States of America (with contributions by J.H. Luetgert, W.A. Bothner, K.D. Klitgord, L.M. Liberty, Carl Spencer), US Geological Survey Miscellaneous Investigations Series Map I-2329, 17 scale $1: 1,000,000$

Stewart, D.S., Tucker, R.D., West, D.P., 1995. Genesis of Silurian composite terrane in northern Penobscot Bay. In: Hussey II, A.M., Johnston, R.A. (Eds.), Guidebook to Field Trips in Southern Maine and Adjacent New Hampshire, Bowdoin College, New England Intercolletiate Geological Conference, 87th Annual Meeting, Brunswick, ME, pp. 29-49.

St. Julien, P., Slivitsky, A., 1987. Compilation geologique de la region de l'Estrie-Beauce: Quebec Ministere de l'Energie et des Ressources, MM 85-04, 40 pp., map scale 1:250,000.

Thompson Jr., J.B., Robinson, P., Clifford, T.N., Trask Jr., N.J., 1968. Nappes and gneiss domes in west-central New England. In: Zen, E-an et al. (Eds.), Studies of Appalachian Geology-Northern and Maritime. Interscience Publishers, New York, pp. 203-218.

Tremblay, A., Pinet, N., 1994. Distribution and characteristics of Taconian and Acadian deformation, southern Quebec Appalachians. Geological Society of America Bulletin 106, 1172-1181.

Tremblay, A., Malo, M., St.-Julien, P., 1995. Dunnage zone in Quebec. In: Williams, H. (Ed.), Geology of the Appalachian-Caledonian Orogen in Canada and Greenland: Geological Survey of Canada, Geology of Canada, no. 6, pp. 179-197 (Chapter 3).

Tremblay, A., Ruffet, G., Castonguay, S., 2000. Acadian metamorphism in the Dunnage zone of southern Quebec, northern Appalachians: ${ }^{40} \mathrm{Ar} /{ }^{39} \mathrm{Ar}$ evidence for collision diachronism. Geological Society of America Bulletin 112 (1), 136-146.

Trzcienski Jr., W.E., Rodgers, J., Guidotti, C.V., 1992. Alternative hypotheses for the Chain Lakes "massif", Maine and Quebec. American Journal of Science 292, 508-532.

Tucker, R.D., McKerrow, W.S., 1995. Early Paleozoic chronology: a review in light of new $\mathrm{U}-\mathrm{Pb}$ zircon ages from Newfoundland and Britain. Canadian Journal of Earth Sciences 32, 368-379.

Tucker, R.D., Robinson, P., 1990. Age and setting of the Bronson Hill magmatic arc: a re-evaluation based of $\mathrm{U}-\mathrm{Pb}$ zircon ages in southwestern New England. Geological Society of America Bulletin 102, 1404-1419.

van Staal, C.R., 1994. Brunswick subduction complex in the Canadian Appalachians: record of the Late Ordovician to Silurian collision between Laurentia and the Gander margin of Avalon. Tectonics 13 (4), 946-962.

van Staal, C.R., de Roo, J.A., 1995. Mid-Paleozoic tectonic evolution of the Appalachian central mobile belt in northern New Brunswick, Canada: Collision, extensional collapse and dextral transpression. In: Hibbard, J.P, van Staal, C.R., Cawood, P.A. (Eds.), Current Perspectives in the Appalachian-Caledonian Orogen; Geological Association of Canada, Special Paper 41, pp. 367-389.

van Staal, C.R., Sullivan, R.W., Whalen, J.B., 1996. Provenance and tectonic history of the Gander zone in the aledonian/Appalachian orogen: Implications for the origin and assembly of Avalon, Geological Society of America Special Paper 304, pp. 347-367.

van Staal, C.R., Dewey, J.F., Mac Niocaill, C., McKerrow, W.S., 1998. The Cambrian-Silurian tectonic evolution of the northern Appalachins and British Caledonides: History of a complex, west and southwest Pacific-type segment of Iapetus. In: Blundell, D.J., Scott, A.C. (Eds.), Lyell: the Past is the Key to the Present, Geological Society of London Publications, vol. 143, pp. 199-242.

van Wagoner, N.A., McNeil, W., Fay, V., 1988. Early Devonian bimodal volcanic rocks of southwestern New Brunswick: petrology, stratigraphy, and depositional setting. Maritime Sediments and Atlantic Geology 24, 310-319.

Walsh, G.J, Aleinikoff, J.N., 1999. U-Pb zircon age of metafelsite from the Pinney Hollow Formation: implications for the development of the Vermont Appalachians. American Journal of Science 299, 157 170.

Wellensiek, M.R., van der Pluijm, B.A., Van der Voo, R., Johnson, R.J.E., 1990. Tectonic history of the Lunkoos composite terrane in the Maine Appalachians. Tectonics 9 (4), 719-734.

West Jr., D.P., Guidotti, C.V., Lux, D.R., 1995. Silurian orogenesis in the western Penobscot Bay region, Maine. Canadian Journal of Earth Science 32, 1845-1858.

West Jr., D.P., Ludman, A., Lux, D.R., 1992. Silurian age for the Pocomoonshine gabbro-diorite, southeastern Maine and its regional implications. American Journal of Science 292, 253-273.

Whalen, J.B., Rogers, N., van Staal, C.R., Longstaffe, F.J., Jenner, G.A., Winchester, J.A., 1997. Geochemical and isotopic (Nd, O) data from Ordovician felsic plutonic and volcanic rocks of the Miramichi Highlands: petrologic and metallogenic implications for the Bathurst mining camp. Canadian Journal of Earth Sciences 35, 237-252.

Whitehead, J., Spray, J.G., Dunning, G., 1996. Oceanic emplacement related $\mathrm{U}-\mathrm{Pb}$ zircon ages from the Thetford Mines ophiolite, Quebec Appalachians. Geological Society of America Abstract with Programs 28 (7), A-438.

Williams, H., Coleman-Sadd, Swinden, H.S., 1988. Tectonic-stratigraphic divisions of central Newfoundland, in Current Research, Part B: Geological Survey of Canada, Paper 88-1B, pp. 91-98.

Winchester, J.A., van Staal, C.R., 1994. The chemistry and tectonic setting of Ordovician volcanic rocks in northern Maine, and their relationship to contemporary volcanic rocks in northern New Brunswick. American Journal of Science 294, 941-962.

Wintsch, R.P., Sutter, J.F., Kunk, M.J., Aleinikoff, J.N., 1993. Alleghanian assembly of Proterozoic and Paleozoic lithotectonic terranes in south central New England: New constraint from geochronology and petrology. In: Cheney, J.T., Hepburn, J.C. (Eds.), Field Trip Guidebook for the Northeastern United States1993 Boston GSA, vol. 1, Department of Geology and Geography, University of Massachusetts, Contribution no. 67, Amherst, MA, H-1-H-30.

Wintsch, R.P., Sutter, J.F., Kunk, M.J., Aleinikoff, J.N., Dorais, M.J., 1992. Contrasting $D-T-t$ paths: thermochronologic evidence for a Late Paleozoic final assembly of the Avalonian composite terrane in the New England Appalachians. Tectonics 11, 672-689.

Zartman, R.E., Leo, G.W., 1985. New radiometric ages on gneisses of Oliverian domes in New Hampshire and Massachusetts. American Journal of Science 285 (3), 267-280. 
Zartman, R.E., Naylor, R.S., 1984. Structural implications of some radiometric ages of igneous rocks in southeastern New England. Geological Society of America Bulletin 95, 539-552.

Zen, E-an, 1989. Tectonostratigraphic terranes in the New England Appalachians: their distribution, origin, and age, evidence for their existence: 28th International Geological Congress, Washington, D.C., July 9-19, 1989, Field Trip Guidebook T359, 68 pp.

Zhang, L-S., Shärer, U., 1996. Inherited $\mathrm{Pb}$ components in magmatic titanite and their consequence for the interpretation of $\mathrm{U}-\mathrm{Pb}$ ages. Earth and Planetary Science Letters 138, 57-65. 